\author{
Universidade de São Paulo \\ Faculdade de Saúde Pública \\ Departamento de Política, Gestão e Saúde
}

\title{
O cuidado em Rede no Fórum de Reabilitação da Freguesia do Ó e Brasilândia
}

Renata Pereira Sanches Guardia

Dissertação apresentada para avaliação escrita no Programa de Pós-Graduação em Saúde Pública da Faculdade de Saúde Pública da Universidade de São Paulo para obtenção do título de Mestre.

Área de Concentração Política, Gestão e Saúde.

Orientadora: Profa. Dra. Yara Maria Carvalho

São Paulo

2019 


\section{O cuidado em Rede no Fórum de Reabilitação da Freguesia do Ó e Brasilândia}

Renata Pereira Sanches Guardia

Dissertação apresentada para avaliação escrita no Programa de Pós-Graduação em Saúde Pública da Faculdade de Saúde Pública da Universidade de São Paulo para obtenção do título de Mestre.

Área de Concentração Política, Gestão e Saúde.

Orientadora: Profa. Dra. Yara Maria Carvalho

\section{Versão Corrigida}

São Paulo 
Autorizo a reprodução e divulgação total ou parcial deste trabalho, por qualquer meio convencional ou eletrônico, para fins de estudo e pesquisa, desde que citada a fonte. 
Dedico este trabalho aos diversos usuários e usuárias que me provocaram deslocamentos importantes no processo de cuidado, o que me moveu a produzir a presente pesquisa. 


\section{AGRADECIMENTOS}

Agradeço às diversas pessoas que estiveram presentes nesta trajetória. Em especial, agradeço:

À minha família que sempre que me dá força e apoio para que todos os meus projetos de vida sejam possíveis. À minha vó Fifi, por ter sido a melhor vó do mundo e por ter me ensinado muito sobre cuidado. À minha mãe, Maria Lucia, por ter me ensinado muito sobre respeito à diferença e a quem devo minhas inquietações com o mundo. À Ciça, minha tia, agradeço o incentivo aos estudos e à leitura, essencial para que eu pudesse trilhar esse caminho, além das contribuições com a revisão da presente dissertação. À Maria, minha tia, agradeço a força e intensidade, além do apoio necessário. À Irene, minha tia, pelo carinho, apoio e amabilidade.

Aos meus irmãos, Daniela e Arthur, por estarem sempre presentes e por me apoiarem nesse percurso. Assim como aos meus primos-irmãos que também sempre se fazem presente. Aos meus tios Zé e Euzébio pela disponibilidade de discutir ideias. Aos meus sobrinhos Bia, Eric e Henrique eu agradeço os deslocamentos que o encontro com eles me provoca. Ao Lucca, meu sobrinho-neto, eu agradeço os abraços e a amabilidade.

Às participantes do Fórum de Reabilitação por dividirem comigo o desejo e a Utopia de produzir uma Rede que seja de cuidado, assim como pela contribuição para que a presente pesquisa fosse possível.

Às amigas e aos amigos pela paciência para ouvirem minhas lamentações, a companhia reconfortante em momentos difíceis, assim como a alegria de compartilhar diversos momentos agradáveis.

À capoeira e às/aos capoeiristas pelas noites que me transportam para um mundo outro.

Às NIRzetes, companheiras de trabalho e amigas na vida, por todo apoio, acolhimento e compreensão. Mas em especial, agradeço o acolhimento de todas as angústias que o cuidado me produz, o que me dá força para continuar.

À Juliana, minha chefe, agradeço a disponibilidade, a flexibilidade e todo apoio muito necessário para que o processo de escrita fosse possível. Agradeço especialmente a inspiração 
que me produz, com constante esforço e persistência em fazer uma unidade de saúde possível, onde usuários e trabalhadores sejam cuidados apesar de todas as dificuldades enfrentadas.

Às/aos MC's, companheiras(os) de trabalho, agradeço o apoio, o coleguismo, e o esforço constante, que faz possível sustentarmos uma unidade de saúde.

Às companheiras e companheiros do grupo de pesquisas agradeço a amizade, o apoio, as contribuições teóricas, o acolhimento e todo tipo de ajuda despendida, em especial na contingência da escrita da presente dissertação, que fez toda diferença.

À Yara, agradeço a abertura, o acolhimento, a orientação e as provocações feitas, que não só contribuíram para o percurso do mestrado, mas para produção de vida.

À Laura, agradeço a abertura, o acolhimento e os deslocamentos produzidos, que mudaram tudo e possibilitaram uma pesquisa sobre cuidado.

Ao grupo de Micropolítica por contribuir com meu processo de estudo e conhecimento.

Às pessoas com as quais eu me encontrei em um processo de cuidado pela confiança, carinho e potência de vida que agenciam em mim.

À Rosemary Haberland pelas contribuições, amizade e apoio.

À Vera Rocha pelas contribuições na qualificação do projeto.

Às professoras Ana Carolina Schmitt e Simone Ramalho pela abertura, disponibilidade e pelas preciosas contribuições.

A todas e a todos Muito Obrigada! 


\section{RESUMO}

\section{GUARDIA, RPS. O cuidado em Rede no Fórum de Reabilitação da Freguesia do Ó e}

Brasilândia. [dissertação de mestrado]. Faculdade de Saúde Pública, Universidade de São Paulo, São Paulo, 2019.

O objetivo é olhar para a produção de rede e contribuir para o processo de reorientação das práticas, relacionados ao cuidado da pessoa com deficiência na STS FÓ/Brasilândia, assim como contribuir com a literatura da área. O campo de pesquisas é o Fórum de Reabilitação, por ser um dispositivo de Rede. A pesquisa é qualitativa, no âmbito do SUS. Nessa proposta de pesquisa realizo um mapeamento que não é estático e está sujeito aos movimentos da rede, que é viva, com intensão de dar visibilidade aos processos do cotidiano dos serviços, captando a dimensão micropolítica. Considerando os efeitos do pesquisar e da interferência que esse ato exerce sobre os processos, os ideais das ciências naturais não foram contemplados. Nos Fóruns são discutidos a conceituação de deficiência, de reabilitação e as práticas de cuidado, onde os casos são apresentados e vamos colocando em análise nosso modo de operar, com participação de trabalhadores e gestores das Supervisões Técnicas de Saúde da Fueguesia do Ó e Brasilândia e da Casa Verde, Cachoeirinha e Limão. Fazem-se presentes os tensionamentos entre as diversas perspectivas de pensar o cuidado à pessoa com deficiência, principalmente entre a biologicista e a social. O contexto político e o desinvestimento da Gestão Municipal assim como Federal são problematizadas como dificultadores da produção de ofertas, assim como fatores a intensificar a precarização em curso dos serviços públicos. A Reabilitação Inventiva vem a contribuir com o direcionamento desse processo de reorientação das práticas, onde outros planos são também produzidos para produção de vida e dos refazimentos necessários após o acontecimento da deficiência.

Palavras-chave: Rede de Cuidado à Pessoa com Deficiência, Fórum de Saúde, Fórum de Reabilitação, Fisioterapia e Saúde Coletiva. 


\begin{abstract}
GUARDIA, RPS. The Care Network in the Rehabilitation Forum of the Freguesia do Ó

and Brasilândia. [master's dissertation]. Faculdade de Saúde Pública, Universidade de São Paulo, São Paulo, 2019.

The objective is to see the Care Network production and contribute with the process of reorientatiions of the practices, related to care of the people with disability in the STS FÓ/Brasilândia, as well as contribute with the literature of the area. The field of research is the Forum of the Rehabilitation, because it is a network device. It is a qualitative research in the SUS. In this research proposal I perform a non static mapping and it is subject to network movements, that is alive, with the purpose of giving visibility to the daily processes of the services, capturing the micropolitical dimension. Considering the research efect and the interference of this act on the processes, the ideals of the natural sciences were not contemplated. In the Forums we discuss the conceptualization of disability, rehabilitation and care practices, where the cases are presented and we are analyzing our way of operating, with the participation of workers and managers of the Technical Supervisions of Health of the Freguesia do Ó and Brasilândia and of the Casa Verde, Cachoeirinha and Limão. The tensions between the different perspectives of thinking about the care of the people with disability, especially between the biologist and the social one, are taken into account. The political context and the disinvestment of the Municipal as well as Federal Management are problematized as difficult of the production of offers, as well as factors to intensify the precarization in course of the public services. Inventive Rehabilitation contributes to the direction of this process of reorientation of practices, where other plans are also produced for the production of life and the necessary reassessments after the event of the disability.
\end{abstract}

Palavras-chave: Network of Care for People with Disability, Health Forum, Rehabilitation Forum, Physiotherapy and Collective Health. 


\section{SUMÁRIO}

$\begin{array}{lr}\text { APRESENTAÇÃOO } & 13\end{array}$

$\begin{array}{lr}\text { 1- INTRODUÇÃO } & 19\end{array}$

2- CAPÍTULO 1: CONTEXTUALIZAÇÃO DO TERRITÓRIO DE SAÚDE:

FREGUESIA DO Ó E BRASILÂNDIA $\quad 24$

2.1 - A UNIVERSIDADE E AS PESQUISAS 24

2.2 - CONTEXTO HISTÓRICO DO TERRITÓRIO DE SAÚDE E

DO MUNICÍPIO 26

2.3 - O BAIRRO DA BRASILÂNDIA: ÍNDICES DE SAÚDE E

MODOS DE OCUPAÇÃO 28

2.4 - POLÍTICA NACIONAL DE HUMANIZAÇÃO (PNH) NO
TERRITÓRIO E A CONSOLIDACCAO DE ESPACOS COLETIVOS

2.5 - A REDE DE CUIDADO EM SAÚDE PARA PESSOAS COM

DEFICIENCIA $\quad 32$

3 - CAPÍTULO 2: PERCURSO PELO CAMPO DE PESQUISAS 35

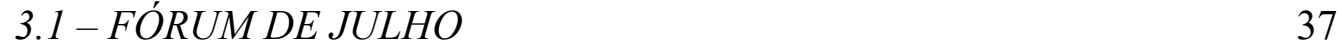

3.1.2 - Propostas para o próximo Fórum $\quad 46$

3.2 - FÓRUM DE AGOSTO 46

3.2.1 - Outras cenas e casos $\quad 52$

3.2.2 - Discussão do mapeamento $\quad 54$

3.3 - FÓRUM DE SETEMBRO

3.3.1 - Visita do CRI (Centro de Referência do Idoso) nas unidades 60

$\begin{array}{ll}3.3 .2 \text { - Propostas } & 60\end{array}$

$3.4-F O ́ R U M D E N O V E M B R O \quad 61$

4- CAPÍTULO 3: O FÓRUM E A REDE 64

5 - CAPÍTULO 4: DEFICIÊNCIA E REABILITAÇÃO DIANTE DO CENÁRIO POLÍTICO DO MUNICÍPIO DE SÃO PAULO: AS DECORRÊNCIAS NAS PRÁTICAS DE SAÚDE E CUIDADO

5.1 - DEFICIÊNCIA E REABILITAÇÃO 75

5.2 - REORIENTAÇÃO DAS PRÁTICAS EM REABILITAÇÃO

NO CENARIO POLÍTICO ATUAL $\quad 79$

5.3 - DIALOGANDO COM OUTRAS PERSPECTIVAS PARA
REVER AS PRÁTICAS DE CUIDADO E REABILITACÃO

6 - CONSIDERAÇÕES FINAIS 92

7 - REFERÊNCIAS $\quad 98$

7.1 - OUTRAS FONTES DE PESQUISAS 101

8- ANEXOS:

103 
8.2 - Anexo 2: AUTOTIZAÇÃO DE PESQUISA NA STS FREGUESIA DO Ó E BRASILÂNDIA

8.3 - Anexo 3: AUTORIZAÇÃO DE PESQUISA COORDENADORIA NORTE

8.4 - Anexo 4: PARECER CONSUBSTANCIADO CEP FSP-USP

8.5 - Anexo 5: PARECER CONSUBSTANCIADO CEP SMS-SP

8.6 - Anexo 6: CURRÍCULO LATTES RENATA PEREIRA SANCHES

GUARDIA

8.7 - Anexo 7: CURRÍCULO LATTES YARA MARIA DE CARVALHO 


\section{LISTA DE SIGLAS}

AACD - Associação de Assistência à Criança Deficiente

ABC - Santo André, São Bernardo e São Caetano

ABRASCO - Associação Brasileira de Saúde Coletiva

APAE - Associação de Pais e Amigos do Excepcional

APD - Estratégia Acompanhante de Saúde da Pessoa com Deficiência

ASF - Associação Saúde da Família

CAPS - Centro de Atenção Psicossocial

CAPS AD - Centro de Atenção Psicossocial Álcool e Outras Drogas

CAPSi - Centro de Atenção Psicossocial Infantil

CCJ - Centro de Convivência da Juventude

CDPD - Convenção Internacional sobre os Direitos das Pessoas com Deficiência

CEFAI - Centro de Formação e Acompanhamento à Inclusão

CEFÓ - Centro Esportivo da Freguesia do Ó

CEP - Comitê de Ética e Pesquisa

CER - Centro Especializado de Reabilitação

CID - Código Internacional de Doença

CLT - Consolidação das Leis Trabalhistas

CNH - Carteira Nacional de Habilitação

CONASS - Conselho Nacional de Secretários de Saúde

CRAS - Centro de Referência da Assistência Social

CREFITO - Conselho Regional de Fisioterapia e Terapia Ocupacional

CRI - Centro de Referência do Idos

CROSS - Central de Regulação de Ofertas de Serviços de Saúde

CVI - Centros de Vida Independente

DATASUS - Departamento de Informática do Sistema Único de Saúde

ECNE - Encefalopatia Crônica não Evolutiva

FCM - Faculdade de Ciências Médicas

FMRP-USP - Faculdade de Medicina de Ribeirão Preto da Universidade de São Paulo

FÓ - Freguesia do Ó 
GTH - Grupo de Trabalho de Humanização

HC-FMRP-USP - Hospital das Clínicas da Faculdade de Medicina de Ribeirão Preto da Universidade de São Paulo

IBGE - Índice Brasileiro de Geografia e Estatística

MS - Ministério da Saúde

NASF - Núcleo de Apoio à Saúde da Família

NIR - Núcleo Integrado de Reabilitação

NISA - Núcleo Integrado de Saúde Auditiva

ONG - Organização Não governamental

ONU - Organização das Nações Unidas

OPAS - Organização Pan-Americana de Saúde

OPM - Órteses, Próteses e Meios Auxiliares de Locomoção

OSS - Organização Social de Saúde

PAS - Programa de Atendimento à Saúde

PEC - Projeto de Emenda Constitucional

PET - Programa de Educação para o Trabalho

PIB - Produto Interno Bruto

PICS - Práticas Integrativas e Complementares em Saúde

PNH - Política Nacional de Humanização

PUC-SP - Pontifícia Universidade Católica de São Paulo

RAPS - Rede de Atenção Psicossocial

RAS - Rede de Atenção em Saúde

RBC - Reabilitação Baseada na Comunidade

SEAD - Sistema Estadual de Análises de Dados

SIGA - Sistema

SIGTAP - Sistema de Gerenciamento de Tabela

STS - Supervisão Técnica de Saúde

SUS - Sistema Único de Saúde

TCLE - Termo de Consentimento Livre e Esclarecido

UBS - Unidade Básica de Saúde

UNA-SUS - Universidade Aberta do SUS 
UNICAMP - Universidade Estadual de Campinas

USP - Universidade de São Paulo

VER-SUS - Vivências e Estágios na Realidade do Sistema Único de Saúde 


\section{APRESENTAÇÃO}

Apresento meu percurso profissional, devido à sua importância para que eu encontrasse certos problemas e estruturasse um projeto de pesquisa que tivesse resultado à presente dissertação. Sou fisioterapeuta, graduada pela Faculdade de Medicina de Ribeirão Preto da Universidade de São Paulo (FMRP-USP). Minha prática profissional sempre se deu no Sistema Único de Saúde (SUS), iniciada pelo estágio curricular da graduação.

Em seguida cursei o programa de Aprimoramento Profissional em Fisioterapia Cardiorrespiratória no Hospital das Clínicas da FMRP-USP (HC-FMRP-USP). Foi um ano de intensidade ímpar, com muito trabalho e aprendizado e fundamental importância para a minha formação, principalmente em relação à problematização do cuidado. A complexidade dos casos, o desgaste físico e emocional que o trabalho naquele lugar produzia, a falta de recursos que colocava a vida das pessoas em risco, a sobrecarga de trabalho, o adoecimento de trabalhadores que os tornavam insensíveis às necessidades dos usuários, a negligência, a morte, o sofrimento, o descuidado, a falta de acolhimento, a necessidade de constantes enfrentamentos com as diferentes equipes me desgastaram bastante nesse período. Em paralelo ao Aprimoramento iniciei a Especialização em Acupuntura e apesar de ter me identificado com a técnica e esse outro olhar para o corpo, eu nunca a exerci profissionalmente.

Após o término do Aprimoramento fui contratada pela Fundação do ABC para trabalhar em São Bernardo do Campo na Policlínica de Reabilitação Infantil, serviço municipal, onde eu fazia reabilitação nas áreas de ortopedia, neurologia e hidroterapia infantil. Nesse período o que me chamou especial atenção era a percepção das crianças que não se viam como deficientes e não achavam que precisavam de fisioterapia e também não apresentavam queixas relacionadas à deficiência. A fisioterapia como necessidade de saúde era apenas percebida por mim e pelos seus pais. Diversos casos e encontros com os usuários foram produzindo deslocamentos e questionamentos. Qual cuidado eu estava produzindo e como isso interferiria na vida das pessoas? Será que essas crianças precisavam de fisioterapia? Percebi que estava produzindo a consciência da deficiência nas crianças e isso poderia causar sofrimento. Por outro lado, acolhi um usuário que não teve acesso à reabilitação quando criança e como consequência desenvolveu deformidades e prejuízos funcionais que causaram impacto importante no seu desenvolvimento e participação social. Isso reafirmava a necessidade das crianças passarem pelo processo de reabilitação/habilitação. Como fazer isso da melhor maneira possível? 
Em seguida, a Policlínica de Reabilitação Infantil se integrou a outros serviços para constituirmos as equipes que formariam o Centro Especializado de Reabilitação (CER) de São Bernardo do Campo e passamos pelo processo de estruturação das equipes, de reorientação das práticas e de implantação do CER. Neste momento fui para a equipe de Amputados. A complexidade do cuidado de adultos em condições clínicas instáveis, emocionalmente fragilizados, a longa espera pelas próteses, assim como a delicada relação deles com seus corpos me colocavam outros desafios, exigindo a elaboração de outras tecnologias relacionais. A prótese como tecnologia assistiva adquiria um significado para além dos limites objetivamente e cientificamente estabelecidos para a mesma. Era a possibilidade de reconstrução de um corpo, de reconstrução de uma vida, de acordo com as expectativas com que os usuários a projetavam. Perguntavam sobre quando chegaria ou quando eu faria a solicitação da "perna" deles, eu enfatizava que era uma prótese e não uma perna, cuja diferença eles só iriam experienciar quando a prótese se concretizasse.

Por outro lado, a espera era maior que um ano para essa prótese, o que gerava muita ansiedade. Era minha responsabilidade fazer essas prescrições. Isso implicava em não as prescrever para os usuários que não apresentassem condições clínicas e físicas para a marcha com prótese. Devido ao contexto exposto, estes eram sempre momentos muito difíceis, porque eu tinha que lidar com a frustração dos usuários e seus familiares.

Exemplificando, uma usuária com amputação transfemural bilateral, que anteriormente à segunda amputação não havia se adaptado ao uso da prótese, acrescidos outros elementos de avaliação, não atendia a critérios que a elegeriam para uso de próteses bilaterais. No entanto, a mesma manifestava o desejo de comprar próteses do tipo stubbies. Após longas conversas comigo e com a psicóloga e alguns meses de fisioterapia, na tentativa de fazer outras ofertas, ela continuava manifestando a vontade de tentar o uso das mesmas e insistiu para que eu fizesse a prescrição e eu a fiz. Entretanto, ela não conseguiu se adaptar, mesmo fazendo duas horas semanais de sessões individuais de fisioterapia, assim como muito investimento para que a marcha com as próteses fosse possível. Isso me fazia afirmar que, de algum modo, o conhecimento técnico-científico, mesmo voltado para uma determinação funcionalista e biologicista dos corpos, possibilitava a produção de algumas verdades com valor de uso naquele contexto, mesmo considerando que há diversos elementos presentes na adaptação a uma prótese, assim como referentes à produção da necessidade da mesma.

Em um curso na AACD de reabilitação em amputados assisti ao vídeo de uma criança com agenesia congênita de membros e ela se locomovia, subia e descia da cama elástica, brincava com as panelinhas. Fiquei... eu ia dizer impressionada, mas na realidade não sei qual 
palavra expressaria isso, pois era algo completamente inesperado, não havia nos meus registros mentais a possibilidade de pensar que isso poderia acontecer. Hoje, sendo ativada por essa memória, penso em como cuidar e permitir que esse inusitado, inesperado, impensável possa ser praticado. Como não limitar com as minhas práticas essas possibilidades? Essa cena me faz pensar sobre quantos pressupostos eu acesso quando estou em contato com os usuários. Eu não pensaria na possibilidade de uma vida independente vendo essa criança em outra cena, que poderia estar sentada em uma cadeira de rodas.

Atualmente trabalho como fisioterapeuta, vínculo estatutário com a Prefeitura Municipal de São Paulo, no Núcleo Integrado de Reabilitação Maria Cecília Ferro Donnângelo (NIR Maria Cecilia), localizado na Unidade Básica de Saúde (UBS) de mesmo nome, no bairro da Brasilândia. Ao longo destes oito anos de exercício da profissão, fui-me formando fisioterapeuta. A graduação possibilitou o aprendizado das patologias e das técnicas terapêuticas. No entanto, apesar de necessários, não foram suficientes para o cuidado com os usuários, o que demanda também tecnologias relacionais que possibilitem um encontro com abertura para a entrada das suas vidas e das suas relações na conversa. O vínculo e a escuta foram aparecendo como ferramentas fundamentais para a formulação do Projeto Terapêutico em conjunto com os usuários e familiares, convocando-me a sair dos modelos estabelecidos, a priori, de como "tratar os pacientes", pois a rigidez desse modo de operar não possibilitava produção de saúde e de vida.

Os diversos deslocamentos produzidos no exercício da fisioterapia no SUS mobilizaram-me a buscar interlocutores e conceitos para poder dialogar com esses desconfortos e assim produzir a minha prática e, como consequência, o meu encontro com os usuários de um modo outro.

A disciplina de pós-graduação "Racionalidades e Micropolítica na Produção dos Modelos Tecnoassistenciais", ministrada pela professora Dra. Laura C. M. Feuerwerker, na Faculdade de Saúde Pública da Universalidade de São Paulo (FSP-USP) em 2014, possibilitou-me olhar em uma perspectiva micropolítica a produção das políticas públicas e as implicações no cuidado, de modo muito diferente das minhas outras formações. A partir desse contato passei a frequentar os encontros do grupo de Micropolítica. Ambos tiveram grande importância para me encontrar com interlocutores como a professora Dra. Laura C.M. Feuerwerker e o professor Dr. Emerson Elias Merhy, assim como para eu qualificar o meu problema e projeto de pesquisa.

A disciplina de pós-graduação "Regionalização e Regulação das Redes de Atenção à Saúde", ministrada pela professora Dra. Marilia Cristina Prado Louvison, na FSP-USP em 
2016, foi um convite para pensar a regulação de uma forma mais "quente", mais potente, e como uma ferramenta na produção do cuidado. Regulação sendo produzida como uma ação macro e micropolítica. Problematizamos os diversos vetores que atravessam e produzem demandas, como é o caso da indústria farmacêutica e da mídia, assim como os próprios profissionais de saúde. A disciplina contribuiu para eu perceber a necessidade da regulação não somente pelo número reduzido de vagas de consultas e de procedimentos, mas também porque "criar" demandas não significa um atendimento integral aos usuários. Dialogando com as demandas discutimos a medicalização e medicamentalização da sociedade, o que contribuiu para eu entender de outro modo as necessidades de fisioterapia, assim como as listas de usuários em espera por consultas.

Durante o curso da disciplina de "Metodologia de Pesquisa e Intervenção" ministrada pelas professoras Dra. Yara Maria de Carvalho e Dra. Henriette T. P. Morato, na Escola de Educação Física e Esporte da USP (EEFE) em 2017, trabalhamos pensando sobre possíveis caminhos metodológicos. No decorrer das aulas, formulei algumas questões de pesquisa e outras de ordem metodológica, partindo da proposta de aproximação com Jorge Larrosa Bondía no artigo "Notas sobre a experiência e o saber da experiência" de 2002. A disciplina também me convidou a pensar na minha entrada e preparação para o campo de pesquisa e o parágrafo que segue carrega parte dessa elaboração produzida.

Pensando na entrada no campo de pesquisas preparei-ME para que se configurasse como uma experiência e possibilitasse que coisas $M E$ acontecessem, ME tocassem e $M E$ passassem no processo do pesquisar. Penso que seria a permeabilidade de um corpo que está poroso e receptivo para as diversas vibrações do ambiente, o que possibilitaria estar aberta para ouvir e colher o que $M E$ chega, o que $M E$ afeta e para a experiência. Retomei uma dada definição sobre a pesquisa cartográfica que achei interessante, nesse entendimento a cartografia configura-se como uma pesquisa interferência. Dessa forma, a postura passional proposta por Larossa (2002), que não é ativa e nem passiva, é como entendo que seria essa interferência, onde não há controle dos resultados, nem intervenções nos moldes das pesquisas acadêmicas hegemonicamente produzidas. Seria o oposto de uma postura dominadora, mas tão pouco seria uma postura passiva. Seria a postura de alguém que tem paixão, que é atravessada e afetada pelo campo, que não almeja um distanciamento entre pesquisadora e objeto pesquisado, mas sim uma pesquisa entre sujeitos, dos diversos "EUs" envolvidos e da multiplicidade de sujeitos que vão surgindo no decorrer da pesquisa. Coloco a prática em foco como forma privilegiada de produzir conhecimento e conceitos. 
Acredito que seja necessário escrever para dar visibilidade ao que vem sendo produzido no cotidiano dos serviços, com a intenção manifesta das produções possibilitarem diálogo com outros profissionais da saúde, em especial fisioterapeutas. No entanto, proponhome a fazer pesquisa sobre a rede de cuidados da pessoa com deficiência em uma perspectiva diferente da que hegemônicamente se faz ciência, onde certos recortes são produzidos e os números com frequência recebem lugar de destaque, olha-se para o número de consultas, para o número de atendimentos, para o número de procedimentos, para o número de usuários, para os números da fila de espera, e então os diversos dados tornam-se estatística para análise dos serviços e das redes. Sem negá-la, mas não será contemplada no presente estudo. No modo como percebo esses números nos serviços de saúde, frequentemente a cobrança por eles os faz parecer mais com uma avalanche que nos soterra e nos prende, do que a expressão do cuidado praticado. Esses números nos auxiliam a olhar e produzir certo plano, que tangencia certa realidade, que tem certo valor de uso na saúde, mas acredito que outros modos de olhar as práticas em saúde são necessários para compor com esses dados e possibilitar apreender a complexidade das redes de cuidado que não é quantificável. No entanto, ferramentas teóricas que possibilitem a produção de planos de visibilidade sensíveis à complexidade desse modo de operar tornam-se imprescindíveis.

Penso ser fundamental a produção de rede como estratégia de cuidado para as pessoas com deficiência, assim como a necessidade de extrapolar os limites da clínica convencional para a produção de ofertas inovadoras que sejam também cuidadoras. Acredito ser também imprescindível a problematização das diferentes propostas da área, com vistas a perceber o impacto das nossas práticas para a saúde e o bem-estar dos usuários. 


\section{1- INTRODUÇÃO}

As intervenções terapêuticas podem implicar o usuário para o seu processo terapêutico a fim, de um lado, qualificar o cuidado e, de outro, "autorizá-lo" ao cuidado compartilhado para que tenha mais condições de autonomia e produção/invenção de rede de cuidado, seja com sua família, seja com amigos, seja com usuários, seja com os profissionais da saúde, com um mínimo de desconforto e sofrimento gerados por uma limitação física ou por uma patologia. Nessa perspectiva, o projeto terapêutico, com a coparticipação dos usuários e familiares nas tomadas de decisões, poderia facilitar a criação de outros arranjos no que se refere ao cuidado e às práticas de saúde no sentido, por exemplo, de compor diferentes formas e conteúdos no processo terapêutico.

Os usuários em muitos momentos se valem da sua autonomia para questionar as práticas de saúde. Se não há possibilidade de negociações essa escolha é unidirecional e nem sempre se dá da melhor forma, podendo ser diferente se essas escolhas forem compartilhadas com abertura para produzir diálogo (FEUERWERKER, 2014).

\footnotetext{
Quando um trabalhador de saúde encontra-se com o usuário no interior de um processo de trabalho dirigido à produção de atos de cuidado, estabelece-se entre eles um espaço de interseção que sempre existirá, em ato, em seus encontros. Portanto, no processo de trabalho em saúde há um encontro do agente produtor (com suas ferramentas - conhecimentos, equipamentos - e concepções) e do agente consumidor (com suas intencionalidades, conhecimentos e concepções). Desse modo, o agente consumidor é, em parte, objeto daquele ato produtivo, mas também é um agente ativo, que interfere no processo. (FEUERWERKER, 2014, p.38)
}

Nesse sentido, é necessário permitir que a vida dos usuários com suas conexões e redes existenciais entrem nas conversas e nas unidades de saúde, façam furos nos muros das instituições, para que possamos fazer ofertas que componham com o modo de vida dos mesmos. (MERHY e col, 2014)

O convite que se faz é o de trabalhar com a diversidade de ofertas para dentro do 'muro do serviço', ofertas essas vivenciadas pelos usuários nas diferentes vivências de cidadania. Nesse sentido, a proposta é que os trabalhadores da saúde conheçam esse usuário cidadão nas inúmeras existências que ele produz, cruza, dialoga, tenciona, olha, se afeta, cheira, brinca, canta, dança, salta, equilibra, chora, ri, namora, reza, trabalha - enfim, produz existências desconhecidas e/ou não incluídas nos projetos terapêuticos institucionais.

No entanto, cabe destacar algo muito importante: a proposta de ampliar a visibilidade sobre as inúmeras produções de vida do usuário/cidadão com os vários encontros sociais, culturais que ele produz para fora do muro, que não devem e nem 
podem ser vistos como 'projetos terapêuticos do campo da saúde', com a ideia que sejam uma 'ação de promoção à saúde', com objeto definido e um conjunto de ações para 'promover a saúde'. (MERHY e col, 2014, p.158)

A produção de cuidado opera com altos graus de incerteza, admitindo que cada indivíduo é único e desenvolve relações singulares com uma dada patologia, que difícilmente se manifesta como nos livros e então, o tratamento também se diferencia. (FEUERWERKER, 2014). Feuerwerker discutindo os diversos desafios na produção de cuidado destaca que:

\footnotetext{
Para almejar e conseguir tanto, este trabalho humano tem que ser portador de capacidade de vivificar modos de existências interditados e antiprodutivos e tem que permitir que vida produza vida. Sua "alma", portanto, tem que ser a produção de um cuidado em saúde dirigido a propiciar ganhos de autonomia e de vida dos seus usuários. Esse é um trabalho de alta complexidade, múltiplo, interdisciplinar, intersetorial e interprofissional. E, como veremos adiante, requer gestão compartilhada. (FEUERWERKER, 2014, p.54)
}

Desse modo, as práticas em saúde podem produzir cuidado no sentido de reafirmar as redes existenciais, a autonomia dos sujeitos e a produção de vida, ou podem interditar diversos modos de existência, considerando que é no plano da vida que o cuidado se efetiva. (FEUERWERKER, 2014)

Rocha e Centurião (2007) discutem a necessidade de se rever a formação em saúde orientada pelo modelo hegemônico médico-centrado, onde as ações são pensadas quase exclusivamente pela lógica científica, deixando em segundo plano aspectos sociais e os modos de vida das pessoas. Nesse modelo hegemônico as intervenções em saúde são centradas na doença e excluem a possibilidade de entender o usuário como um agente ativo na construção do seu plano de cuidado, entendendo-o como um agente passivo nesse processo e desconsiderando seus conhecimentos. Isso distancia os profissionais das necessidades de saúde dos sujeitos e da sociedade (ROCHA e CENTURIÃO, 2007). Quando as práticas são orientadas negando a existência de outros planos, como o social e as singularidades dos indivíduos, limitam-se as ofertas de cuidado aos usuários. Desse modo, é ainda atual a urgência de repensar a formação, considerando-a um processo contínuo que permeia o cotidiano em saúde.

Mendes e col. (2016) discutem a produção de cuidado em uma perspectiva micropolítica, e problematizam a inserção do profíssional de educação física nas equipes de saúde, ressaltando que a presença do mesmo não garante o contraponto ao modo de operar no 
bio $^{1}$. Propõem reflexões relacionadas às práticas e posicionamento sobre as políticas que possibilitem ir além da reprodução da norma (MENDES e col, 2016). Relatam a experiência do grupo de práticas corporais em uma Unidade Básica de Saúde (UBS) na região Oeste de São Paulo, em que trazem a preocupação e a dificuldade de não reduzirem os usuários à doença, assim como de escapar do modelo funcionalista e moralizante de pensar o corpo e poder cuidar de outro modo (MENDES e CARVALHO, 2015).

Precisamos propor e sustentar práticas que sejam produtoras de relações boas, alegres e que instiguem encontros que valorizem o indivíduo e o coletivo, suas questões e necessidades, e ainda com aquilo que é do outro. (MENDES e col, 2016, p. 42)

O cuidado em saúde para a pessoa com deficiência no Brasil foi se produzido, historicamente, por meio de entidades da sociedade civil ou filantrópicas, na perspectiva da caridade pública. Esse processo se inicia anterior ao SUS, evidenciando a falta de investimento em políticas públicas para essa população que perdura ainda nos tempos atuais. Campos e colaboradores (2015) consideram que essa agenda não foi priorizada pelo SUS, configurando-se em serviços isolados, com políticas de assistência fragmentadas. O Brasil foi produzindo abordagens dispersas e subfinanciadas sem uma regulação adequada. $\mathrm{O}$ cenário começa a mudar em 2012 com a publicação das Portarias 793 e 835 de 25 de abril de 2012, instituindo a Rede de Cuidados à Saúde da Pessoa com Deficiência no âmbito do SUS, que apresenta regras de financiamento para a efetivação da política. Considerando que financiamento adequado é condição imprescindível para que a intenção e o discurso sejam levados a práticas concretas, as portarias viabilizam volume de recursos orçamentários consistente, ultrapassando os aportes pontuais e eventuais que caracterizaram o financiamento federal até 2011. (CAMPOS e col, 2015)

\footnotetext{
Naturalmente, se o financiamento adequado é necessário, a construção da lógica de cuidados à saúde da pessoa com deficiência é fundamental, porque dá sentido e consistência à nova Rede. O cuidado está pensado em rede, os serviços são organizados em linhas de cuidado, em função das necessidades da população e dos arranjos territoriais. Desse modo, permite-se que a atenção em saúde esteja focada no contexto do território e dê sustentação a projetos terapêuticos singulares, ampliando as possibilidades de equidade e de cuidado integral às pessoas com deficiência. (CAMPOS e col, 2015, p.208)
}

\footnotetext{
${ }^{1}$ É um termo proposto por Valéria Monteiro Mendes e Yara Maria de Carvalho, como modo de operar os processos de cuidado onde a perspectiva biológica se sobrepõe às demais no encontro com o usuário.
} 
No mesmo sentido, Santos (2017) discute as limitações da Política Nacional de Saúde da Pessoa Portadora de Deficiência de 2008 (BRASIL, 2008), que não logrou os avanços necessários. Considera que o Plano Viver Sem Limites (Referências) contribui para complementar e aprimorar a Política anterior, mas ainda há o que avançar quanto à incorporação na prática assistencial dos conceitos presentes nas diretrizes nacionais e internacionais (SANTOS, 2017). Para tanto, o desenvolvimento, o aprimoramento e o fortalecimento da rede de cuidados para a pessoa com deficiência precisa ser estudado e debatido no campo acadêmico, para contribuir com a qualificação da formação profissional (CAMPOS e col, 2015).

Desde o meu ingresso como fisioterapeuta no município de São Paulo são acionados inúmeros encontros de rede para a discussão de possíveis soluções para o cuidado de usuários em espera por fisioterapia. Então, articulações e pactuações vêm sendo efetivadas no território, tecendo rede com equipamentos dentro e fora da saúde. Acredito que operar em rede e articular ações pode significar mudanças na qualidade do serviço, na prática e na saúde de todos: usuários e profissionais.

Nesse percurso, são revistas as práticas profissionais e as ofertas de cuidado para pessoas com deficiência no território da Freguesia do Ó e Brasilândia, em diálogo com um movimento desencadeado pelas políticas nacionais e mundiais sobre a pessoa com deficiência. Produzir outras ofertas de cuidado na Atenção Básica através das Práticas Integrativas e Complementares em Saúde (PICS) é um dos investimentos feitos nesse processo. É valido reafirmar que penso a produção do cuidado no encontro com os usuários, fazendo rede com os diferentes modos de existir com intuíto de ajudá-los a diminuir os desconfortos vivenciados. Para tanto, as ofertas não podem ser engessadas e limitadas a um pacote de atividades para todos.

Considerando ainda que uma mesma equipe de saúde e um mesmo profissional podem ser mais ou menos cuidadores em diferentes cenas, o processo de análise das práticas é importante para qualificar a continuidade do cuidado. (FEUERWERKER, 2014)

O meu objetivo é contribuir para qualificar esse processo de reorientação das práticas de cuidado à pessoa com deficiência, no território de saúde da Supervisão Técnica de Saúde (STS) da Freguesia do Ó e Brasilândia, assim como olhar como se dá a produção desse cuidado em rede. Faz também parte dos meus objetivos contribuir com a literatura da área, 
que carece de estudos onde apareçam os processos de produção dessa rede em uma perspectiva micropolítica. Lugar este que a presença dos trabalhadores traz as discussões à luz daquilo que acontece no cotidiano dos serviços, no encontro destes com os usuários. O Fórum de Reabilitação é o meu campo de pesquisa, trata-se de um espaço de conversa que participam trabalhadores e gestores da STS da Freguesia do Ó e Brasilândia e da STS da Casa Verde, Cachoeirinha e Limão e acredito ser um lugar privilegiado de articulação da rede, com abertura para que a pesquisa fosse construída junto com as participantes. 


\title{
2- CAPÍTULO 1: CONTEXTUALIZAÇÃO DO TERRITÓRIO DE SAÚDE: FREGUESIA DO Ó E BRASILÂNDIA
}

\author{
2.1 - A UNIVERSIDADE E AS PESQUISAS
}

\begin{abstract}
Se ficássemos só no formal, seria insuficiente. Na Brasilândia, existe uma contratualidade nas ações. A forma como a população se organiza (rede comunitária), numa presença ativa, impede que os trabalhadores reduzam sua ação ao território formal. A vulnerabilidade nos convoca. A capacidade de sobrevivência, a potência e a criatividade nos encantam. O macro é importante por indicar um caminho a seguir, um sentido a se imprimir dentro de uma lógica e de metodologias próprias, mas ele, por si só, é insuficiente. O diálogo macro-micro é imprescindível, porque na sua ausência o serviço que opera numa lógica normativa será um serviço morto, operando sem um sentido, sem um propósito e sem vínculo com os sujeitos do território, e por isso tudo reproduzindo uma lógica reducionista. (Oficina de Escrita, 2014) (ROSA e col, 2016, p.56)
\end{abstract}

No município de São Paulo o SUS é regionalizado em Coordenadorias de Saúde subdivididas em Supervisões Técnicas de Saúde (STS). Meu local de trabalho é na Coordenadoria Norte na STS Freguesia do Ó e Brasilândia (STS FÓ/Brasilândia).

Esse território apresenta-se com frequência como campo de pesquisas, tanto devido a alguns trabalhadores que são pesquisadores, quanto à presença da Pontifícia Universidade Católica campus São Paulo (PUC-SP) e da residência multiprofissional. É também campo de estágio dos alunos de graduação da PUC-SP das áreas de fisioterapia, fonoaudiologia, psicologia e terapia ocupacional.

O Programa de Educação pelo Trabalho para a Saúde (PET-Saúde) foi instituído em 2010 com inspiração no Programa de Educação Tutorial (PET) do Ministério da Educação (BRASIL, 2010a). Na Freguesia do Ó e Brasilândia esse projeto assumiu os formatos: PETSaúde Mental e PET-Saúde/Redes. Essas pesquisas foram desenvolvidas pela PUC em conjunto com a Supervisão Técnica de Saúde do território e publicadas em livro no ano de 2016 (VINCENTIN e col, 2016a). Livro este que contou com a contribuição de Isabela Silva de Almeida, terapeuta ocupacional do Centro de Apoio Psicossocial Álcool e Drogas III na Brasilândia (CAPS AD III), cuja dissertação de mestrado (ALMEIDA, 2015) conversa com as 
citadas pesquisas. A partir dessas fontes contextualizo o território de saúde sob a gestão da STS FÓ/Brasilândia.

O Programa Nacional de Reorientação Profissional para a Saúde (Pró-Saúde) foi criado em 2005 pelo Ministério da Saúde em conjunto com o Ministério da Educação, visando reordenar a formação de recursos humanos (BRASIL, 2005). Em 2008, esse programa de pesquisa foi desenvolvido no território pela PUC-SP em parceria com a STS FÓ/Brasilândia e a Organização Social de Saúde (OSS) Associação Saúde da Família (ASF), denominado Pró-Saúde II. Essa pesquisa possibilitou identificar a necessidade de ampliação e de complexificação das respostas para o cuidado em reabilitação e saúde mental, assim como de educação permanente das equipes e de fortalecimento dessas redes de cuidado. Nesse sentido, foram posteriormente desenvolvidos os projetos: PET-Saúde Mental (2012-2014) e PET-Redes (2013-2014). (VINCENTIN e col, 2016b)

No PET-Redes, projeto: "Fortalecendo a rede de cuidado da pessoa com deficiência no território da FÓ/Brasilândia: a presença da atenção básica", a reabilitação e o cuidado da pessoa com deficiência passaram a ter investimento em pesquisa. Esse projeto faz o convite à Atenção Básica a pensar sobre o tema em conjunto com os serviços de reabilitação. O estudo possibilita rever as necessidades de saúde desses sujeitos, pensando o conceito de deficiência também como um conjunto de desvantagens sociais. Informações mais precisas produzidas pela pesquisa contribuem com a revisão das ofertas dos serviços de saúde. (VINCENTIN e col, 2016b)

A parceria da PUC com a STS FÓ/Brasilândia acontecia antes do Pró-Saúde, mas este possibilitou avanços no planejamento e execução das atividades de ensino nas unidades de saúde, contribuindo para a formação interdisciplinar e um fazer compartilhado entre serviço e universidade, elaborando conjuntamente diagnóstico, avaliação, monitoramento e planejamento, com corresponsabilização pelo que estava sendo criado ou produzido. (VINCENTIN e col, 2016b)

A PUC e suas pesquisas produzem interferências e certo modo de olhar para a própria pesquisa, para o cuidado, para a saúde, para o território e também para a formação, sendo uma linha de força importante que compõe o território, bastante evidente no Pró-saúde e no PETsaúde, onde é proposto em conjunto com a gestão, a territorialização como eixo organizador das ações. Essa foi a estratégia adotada para orientar o planejamento e o desenvolvimento da 
pesquisa e, como consequência, da organização das redes de cuidado no território. (ROSA e col, 2016)

No texto da autora Simone Alves de Carvalho (2015) é relatada a sua experiência no projeto Vivências e Estágios na Realidade do Sistema Único de Saúde (VER-SUS). A partir da sua formação na área de comunicação e arte, o território é descrito por ela de um modo outro que o habitual. Isso vai evidenciando como as práticas, as vivências, a formação acadêmica, entre outras, vão produzindo filtros para a apreensão dos contextos. A diversidade e a entrada de novos autores possibilitam emergir diferentes planos de visibilidade sobre o território de saúde, e há abertura para isso na FÓ/Brasilândia.

\section{2 - CONTEXTO HISTÓRICO DO TERRITÓRIO DE SAÚDE E DO MUNICÍPIO}

Em São Paulo, os trabalhadores/militantes da saúde mental se identificam como mentaleiros. Na Zona Norte eles fizeram um percurso importante e ganharam notoriedade, produzindo um movimento pioneiro na saúde pública e tornaram-se referência para as outras áreas da saúde, com avanços importantes para a consolidação do SUS e alinhamento de projeto político. Isso trouxe investimentos para o território.

O Projeto Zona Norte, desenvolvido na década de 80, visava à integração das ações de saúde mental, à prevenção de internações psiquiátricas e à criação de procedimentos terapêuticos não cronificadores, com investimento na formação de profissionais. Mobilizou o território com a criação de serviços extra-hospitalares para saúde mental, unidade de emergência de psiquiatria e pronto atendimento em saúde mental para cuidar dos usuários em crise. Foi também proposto equipar a região com mais postos de saúde, entre outros serviços. Nesse período, o distrito sanitário da Nossa Senhora do Ó abrangia as atuais STS Freguesia do Ó/Brasilândia e STS Pirituba/Jaraguá. “A implantação desses serviços foi a primeira experiência de assistência integrada e regionalizada em saúde mental na cidade, com um importante engajamento dos profissionais envolvidos (alguns atuam até hoje no território)". (ANDRADE e col, 2016, p.35) 
Em 1986 a gestão municipal alterou-se, o projeto Zona Norte foi descontinuado e em 1987 iniciado o recadastramento de Hospitais Psiquiátricos. Houve uma tentativa de fechamento do Ambulatório de Saúde Mental da Brasilândia, que posteriormente se tornaria o CAPS II, mas a luta de trabalhadores e usuários impediu que isso se concretizasse (ANDRADE e col, 2016), evidenciando a força de mobilização e organização popular para reivindicação do direito à saúde nesse território.

A história do território, assim como os relatos de trabalhadores, deixa evidente que a rede de saúde pública no município de São Paulo vem alternando períodos de avanço e de retrocesso, à medida que as gestões municipais se alteram. Mas isso não acontece sem resistência. A população e os trabalhadores de saúde usam diversos mecanismos para assegurar que alguns processos não sejam desmantelados, na micropolítica do cotidiano, no encontro com os usuários e nas redes entre os diversos profissionais e outros equipamentos, até mesmo para além da saúde, alguns processos e conquistas conseguem ser sustentados à revelia da gestão municipal. (ANDRADE e col, 2016)

O Plano de Atendimento à Saúde (PAS), como já é bastante conhecido, foi um fator importante para a descontinuidade dos projetos de saúde, que vinham sendo implementados no município de São Paulo, representou retrocesso para a consolidação do SUS e atraso do processo de municipalização da saúde (ANDRADE e col, 2016). Diversos trabalhadores dessa época relatam que ficaram "exilados da saúde", em outras secretarias, produziam linhas de fuga para sobreviver naquelas cenas de desmonte dos projetos que estavam sendo desenvolvidos.

No entanto, as mobilizações comunitárias, em conjunto com trabalhadores da saúde, disputaram ativamente o modo de produzir saúde no território da FÓ/Brasilândia, pleiteando maior poder decisório e interferindo nas escolhas políticas, como a manutenção da gerência da UBS Maria Cecília Ferro Donnangelo, que seria substituída pela gestão do então prefeito Paulo Maluf. Essa resistência garantiu que as mudanças não fossem mais nefastas nesse período do PAS. (ANDRADE e col, 2016)

Em anos mais recentes, na gestão dos prefeitos José Serra e Gilberto Kassab, as OSS passaram a não somente fazer a contratação de profissionais, mas também a gerir os equipamentos de saúde, com gestão e organização próprias, aumentando a fragmentação da 
saúde pública em São Paulo. Na STS FÓ/Brasilândia há um esforço de fazer articulação com a gestão das OSS e dos serviços por elas geridos. (ANDRADE e col, 2016)

"Na Brasa tem" era o nome de um guia que a população jovem residente na Brasilândia elaborou para divulgar os projetos de cultura, esporte e ação comunitária do bairro (ROSA e col, 2016). O site não está mais disponível, e não consegui acessar o guia, mas entendo-o como a concretização da mobilização desses atores.

São intercalados momentos em que há aumento da participação popular e outros de diminuição, mas a população frequentemente se organiza para fazer disputas com o poder público, sendo uma força importante na produção de saúde da região. A implantação de algumas unidades de saúde aconteceu em decorrência de reivindicações dos moradores, que também lutaram pelo acesso a outras políticas sociais, dentre elas a educação (ANDRADE e col, 2016). O Centro de Atenção Psicossocial Álcool e outras Drogas (CAPS AD) modalidade III, localizado na Brasilândia, foi um dos serviços conquistados com mobilização da comunidade (ALMEIDA, 2015).

Cabe destacar que a Supervisão Técnica FÓ/Brasilândia tem uma história consistente de construção do SUS no município: uma tradição de movimentos sociais na construção do direito à saúde, desde o final da década de 1970; iniciativas e experiências pioneiras na atenção básica, como o apoio matricial de saúde mental na atenção básica e a presença da equipe de saúde bucal no PSF, desde 1998, com a experiência do Qualis. A articulação dos trabalhadores de saúde no Fórum dos Trabalhadores de Saúde Mental (agora Fórum dos Trabalhadores de Saúde), desde 2000; a experiência de formação de apoiadores institucionais da Política Nacional de Humanização, em 2008, como seu desdobramento no Grupo Técnico de Humanização, em 2010. (VINCENTIN e col, 2016b, p. 24-25)

\section{3 - O BAIRRO DA BRASILÂNDIA: ÍNDICES DE SAÚDE E MODOS DE}

OCUPAÇÃO

O loteamento da Vila Brasilândia ocorreu em 1947 [...] Os primeiros moradores desse loteamento vieram principalmente das moradias populares e cortiços existentes no centro e que foram demolidos para dar lugar às Avenidas São João, Duque de Caxias, Ipiranga, durante a gestão do prefeito Prestes Maia. Começava assim a história de um bairro marcado pela exclusão e pelo abandono. [...]

Essa ocupação se expandiu para o norte de forma desordenada, a partir de processos migratórios de pessoas de outros estados, que se intensificaram com o fluxo de 
migrantes do nordeste do país na década de 1950 e 1960 [...] A partir desse período, o território se caracteriza por ocupações de áreas de mananciais e superpopulação, predominantemente pessoas de baixa renda. (ROSA e col, 2016, p.56)

É o distrito de São Paulo com maior número absoluto de pessoas negras, em porcentagem é a segunda maior com 10,4\%. E 40,2\% dos habitantes são pardos. Apresenta elevados índices de vulnerabilidade social, violência e homicídio juvenil, violência essa que vitimiza mais negros do que brancos. Há pouca disponibilidade de trabalho formal e baixos salários, as vagas são preenchidas em sua maioria por homens brancos. (ROSA e col, 2016)

Pesquisas mostram iniquidades de saúde relacionadas à questão social, que se expressam em dados de pré-natal insuficiente, muitos moradores em um mesmo domicílio, condições precárias de moradia, diversos domicílios sem coleta de lixo e rede de esgoto. A Brasilândia encontra-se entre os bairros da cidade que possuem os piores valores para esses indicadores, dentre outros, apresenta ainda os piores índices de desigualdade social. Em mais de $40 \%$ dos domicílios a renda é de até dois salários mínimos. (ROSA e col, 2016)

$\mathrm{Na}$ pesquisa desenvolvida para cálculo do Índice de Necessidade de Saúde (INS) a Brasilândia apresenta o sexto pior valor do município. Não há hospital na Brasilândia, pois na cidade de São Paulo hospitais e leitos estão concentrados nas áreas centrais, sendo direcionada maior cobertura de Atenção Básica à periferia. Três hospitais são de referência para a STS FÓ/Brasilândia: o Hospital Geral Vila Penteado (estadual) na Freguesia do Ó, assim como o Hospital Municipal Maternidade Dr. Mário de Moraes Altenfelder Silva (conhecido como Maternidade Cachoeirinha) e o Hospital Geral de Vila Nova Cachoeirinha (estadual), ambos localizados no bairro da Vila Nova Cachoeirinha. (ROSA e col, 2016)

$\mathrm{Na}$ Brasilândia a condição social da população, assim como a dificuldade de acesso aos exames mais complexos, às consultas com especialistas e às cirurgias, convoca-nos a repensar a prática e a fazer diversas adaptações, o que torna imprescindível o refinamento do encontro com o usuário e aprimoramento de tecnologia leve, configurando certo modo de produzir cuidado e pesquisa. 


\section{4 - POLÍTICA NACIONAL DE HUMANIZAÇÃO (PNH) NO TERRITÓRIO E A CONSOLIDAÇÃO DE ESPAÇOS COLETIVOS}

A anterior articuladora da reabilitação da STS FÓ/Brasilândia, Rosemary Haberland, em parceria com outros autores publicou um artigo sobre os fazeres coletivos no território, enfatizando a importância da produção conjunta, da cogestão e dos espaços coletivos nesta Supervisão Técnica de Saúde, onde aparecem os diferentes atores que produzem e sustentam esses espaços, dentre eles o grupo de humanização. Os coletivos emergem e dissolvem-se a depender das contingências, alguns grupos se transformam à medida que vão acontecendo. As redes são vivas e há abertura da gestão para que aconteçam desse modo. (HABERLAND e col, 2017)

A PNH no território iniciou-se em 2010 e ajudou a consolidar grupos com múltiplas participações, estimulando o diálogo sobre práticas de gestão e planos de intervenção, aumentando a corresponsabilização dos profissionais envolvidos. O Grupo de Trabalho de Humanização (GTH) da FÓ/Brasilândia elaborou "Cogestão e Redes" como diretrizes a serem trabalhadas, com a intenção de superar a desarticulação do sistema de saúde. Diversas ações desse GTH, dentre elas dois Encontros de Humanização, produziram análises que evidenciam duas necessidades: intensificação do aquecimento das relações entre trabalhadores, gestores e usuários e; aprofundamento da avaliação da situação de saúde, em rede. Isso fez emergir a demanda de instrumentalização conceitual para o enfrentamento dessas dificuldades. (HABERLAND e col, 2017)

"A tônica da FÓ/Brasilândia são os coletivos" é uma frase que ouvi certa vez, evidencia a aposta da supervisão nos fazeres coletivos e configura um modo de fazer gestão, onde na produção ativa dos espaços de discussão e conversa dão abertura para que seja compartilhada.

Em levantamento realizado pelo "II Encontro de Humanização" em 2012, havia 11 Fóruns na região, além de Grupos de Trabalho e outros espaços coletivos, o que expressa essa potência coletiva da rede de saúde. Também são constituídos espaços interinstitucionais e 
intersetoriais, além de microrredes operadas pelas equipes dos serviços de saúde, para poder articular o cuidado de usuários (HABERLAND e col, 2017).

\begin{abstract}
Esses investimentos, o desejo de produzir mudanças dos profissionais que estavam bastante motivados, as discussões do Fórum, que teve também o apoio das Professoras Maria Cecília Bonini Trenche e Laura Wëy Martz do curso de Fonoaudiologia da PUC/SP, geraram muitos movimentos no território, como discussões para: reverter a situação de invisibilidade em que se encontravam as pessoas com deficiência no território; definir os papéis da Atenção Básica e na Atenção Especializada no cuidado dessa população e a articulação dessas instâncias; pensar a inclusão não somente nos serviços de saúde, mas na família, na comunidade, na vida, constituir fluxos e redes solidárias e formar a rede quente que tanto desejamos em consonância com os princípios do SUS da integralidade e equidade. (HABERLAND e col, 2017, p.802)
\end{abstract}

O cuidado à pessoa com deficiência, refletindo o panorama nacional, não teve o investimento necessário no município de São Paulo, com ações inicialmente fragmentadas e aporte financeiro insuficiente para alcançar a complexidade de ofertas que a particularidade do cuidado desses sujeitos exige. Em 2014 o CER (Centro Especializado de Reabilitação) modalidade II da Freguesia do Ó e Brasilândia foi aprovado, o que possibilitou a contratação de profissionais e a provisão da estrutura necessária à sua instalação.

No entanto, ainda em 2009 formou-se uma comissão entre os sete Núcleos de Apoio à Saúde da Família (NASF) da região, que passou a discutir as políticas de reabilitação no território. No ano de 2010, essas discussões passaram a contar com a contribuição das profissionais do NIR e da Estratégia Acompanhante de Saúde da Pessoa com Deficiência (APD). Posteriormente a participação nesse coletivo foi ampliada para outros serviços, transformando-se em um fórum aberto para discussão da política de reabilitação para o território da Freguesia do Ó e Brasilândia, que se iniciou em 2012 como um espaço importante de aposta da gestão e das trabalhadoras envolvidas. (HABERLAND e col, 2017)

O PET-Redes foi desenvolvido de modo a fortalecer e qualificar as discussões do Fórum, possibilitando a contratação da assessoria de Ana Rita de Paula $^{2}$ e Érica Pisaneshi ${ }^{3}$,

\footnotetext{
${ }^{2}$ Psicóloga e doutora. Atua principalmente em Planejamento e Avaliação em Políticas Públicas nos seguintes temas: deficiência, inclusão social, saúde, reabilitação, educação, assistência e desenvolvimento social e trabalho. Fonte: Plataforma Lattes no site: http://lattes.cnpq.br/7218966400359956

${ }^{3}$ Fonoaudióloga contratada pela PUC-SP. Atua principalmente nos seguintes temas: Clínica Fonoaudiológica, Fala Disfluente, Linguagem, Sujeito Fluente, Patologia da Linguagem e Clínica de Linguagem. Fonte: Plataforma lattes no site: http://lattes.cnpq.br/9638215854130647
} 
que contribuíram com discussões conceituais sobre a atenção à pessoa com deficiência, além da participação de professores e estagiários da PUC. A PNH também contribuiu para a consolidação desse espaço. (HABERLAND e col, 2017)

O Fórum de Reabilitação é formado atualmente por duas Supervisões Técnicas de Saúde da Freguesia do Ó e Brasilândia e da Casa Verde, Cachoeirinha e Limão. Como nesta última não há serviços de reabilitação (CER e NIR), os usuários são referenciados para o CER Freguesia do Ó e é nos Fóruns onde esse fluxo vem sendo discutido. Historicamente, a participação mais frequente é de fisioterapeutas, terapeutas ocupacionais, fonoaudiólogas e psicólogas do NIR Maria Cecília, CER-FÓ, NASF e APD. Eventualmente há a presença de pessoas de outros serviços da saúde como UBS, CAPSi e Maternidade Cachoeirinha, de estagiários e residentes, de trabalhadores de equipamentos que não são da saúde, entre outros. Os usuários não participam. Como observo a presença exclusiva de mulheres na maioria dos encontros, eu vou me referir às pessoas participantes do Fórum no feminino, sem intenção de excluir ou negar a presença eventual de homens, mas de reafirmar a produção feminina desse espaço.

Como as UBS habitualmente não participam dos Fóruns, apesar de serem convidadas, delinearam-se outras estratégias para nos aproximarmos da Atenção Básica, como os matriciamentos por UBS, que deram lugar às reuniões de microterritórios subdivididas em Péda-serra, Alto-da-serra e Beira-rio, na Freguesia do Ó e Brasilândia. Essa divisão é utilizada para os matriciamentos de saúde mental. Devido à nova estruturação, iniciamos a conversa sobre qual seria o objetivo desse Fórum, visto que frequentemente eram discutidas as mesmas pautas em ambos os espaços, com a função de articular a rede. No entanto, foi pontuada a necessidade de afirmar o espaço pertencendo a duas supervisões, no entendimento de que outras discussões aparecem a partir disso, e da necessidade de encontro dos profissionais dos dois territórios no Fórum. Estabeleceu-se que os encontros aconteceriam a cada mês em uma das duas supervisões de saúde, com participação de profissionais de ambas. Nesse contexto, propusemos estudar e discutir os conceitos de deficiência e reabilitação, trazendo elementos para pensarmos sobre o modo como produzimos a rede e o cuidado à pessoa com deficiência no território. Nesse momento de reestruturação há participação mais expressiva de trabalhadoras da Atenção Básica e de outros serviços. Retomamos a frequente discussão sobre 
os fluxos e encaminhamentos para os serviços de reabilitação, dentre eles os Núcleos Integrados de Saúde Auditiva (NISA).

\section{5 - A REDE DE CUIDADO EM SAÚDE PARA PESSOAS COM DEFICIÊNCIA}

O NIR Maria Cecília e o CER II Freguesia do Ó trabalham de modo semelhante e atendem às modalidades de deficiência física e intelectual prioritariamente, mas também de deficiência visual e auditiva e ainda pessoas com disfunções ortopédicas e distúrbios de fala, dentre outros. O NISA Pirituba, referência da região, faz avaliação e diagnóstico da deficiência auditiva e solicita os aparelhos auditivos. Não há serviço de referência para deficiência visual na Zona Norte. Então, encaminhamos alguns usuários para o “LARAMARA Associação Brasileira de Assistência à Pessoa com Deficiência Visual” que é uma associação da sociedade civil sem fins lucrativos, políticos ou religiosos, localizada na Zona Oeste, Barra Funda. As duas equipes de APD (Estratégia Acompanhante de Saúde da Pessoa com Deficiência) compõem o CER, em conjunto com outros profissionais e apresentam o objetivo principal de "fornecer suporte diferenciado às pessoas com deficiência para o cuidado em saúde no território, protagonismo, autonomia, independência e para evitar o abrigamento ou internação". Seu público-alvo são as "pessoas com deficiência intelectual, que necessitam de suporte/apoio para o cuidado em saúde nos diferentes ciclos de vida, bem como ampliação do protagonismo e participação social" (SMS, 2016, p.30). Como explicitado anteriormente, os usuários da STS Casa Verde, Cachoeirinha e Limão que apresentam necessidade de reabilitação de complexidade tal que a Atenção Básica não consiga cuidar, mesmo com apoio do NASF, são referenciados para o CER-FÓ. Além dos dois serviços de reabilitação acima citados, o NIR Guanabara, parceiro da APAE, fica alocado na UBS de mesmo nome, no bairro da Freguesia do Ó. Contamos com um total de três serviços municipais de reabilitação e com cinco equipes de NASF, que dão suporte às equipes da Estratégia Saúde da Família.

Nas STS Pirituba e STS Perus há dois serviços municipais de reabilitação: o NIR Perus e o NIR Taipas. Porém, em decorrência do pequeno número de profissionais, fundiramse em um único NIR, que atualmente possui três trabalhadoras e são referência para as duas 
regiões de saúde, compostas por um total de 5 bairros. Apesar do apoio do NASF, muitos usuários permanecem desassistidos, chegando aos serviços de reabilitação da STS FÓ/Brasilândia.

$\mathrm{Na}$ coordenadoria Norte foi firmado um acordo onde os usuários que acessem os serviços de reabilitação, através da avaliação multiprofissional ou vaga de avaliação específica, tenham garantido o cuidado naquele serviço, ainda que não pertençam à região de saúde. O mesmo pode ser referenciado para o CER ou NIR mais próximo à sua residência, mas esse encaminhamento fica a cargo dos profissionais, não do usuário. Desse modo, eventualmente cuidamos de pessoas que residem em bairros distantes, o que dificulta a articulação em rede do cuidado. 


\section{3 - CAPÍTULO 2: PERCURSO PELO CAMPO DE PESQUISAS}

Para alcançar o objetivo de olhar para a rede de cuidado da pessoa com deficiência, o Fórum de Reabilitação é meu campo de pesquisa no período de julho a novembro de 2018 . Acredito ser um lugar privilegiado de articulação da rede e apresenta visibilidade coerente com aquilo que vem sendo discutido e produzido no território em relação ao modo de operar o cuidado para essa população na STS FÓ/Brasilândia.

Trata-se de uma pesquisa de natureza qualitativa e configura-se como uma intervenção no SUS. Foi submetida e aprovada pelo Comitê de Ética em Pesquisa (CEP) da Faculdade de Saúde Pública da Universidade de São Paulo (FSP-USP) e pelo CEP da Secretaria Municipal de Saúde (SMS) da Prefeitura de São Paulo, pareceres nos anexos quatro e cinco, respectivamente. Os participantes são maiores de 18 anos, sendo que a todos os presentes nos encontros dos Fóruns a pesquisa foi apresentada e forneci duas vias do Termo de Consentimento Livre e Esclarecido (TCLE), no anexo um. A participação das pessoas que não assinaram o TCLE, assim como das trabalhadoras e trabalhadores da STS Casa Verde, Cachoeirinha e Limão, não foi considerada para a descrição do campo de pesquisas. Foram incluídas as participantes que assinaram o TCLE e são trabalhadoras da STS Freguesia do Ó e Brasilândia, assim como as trabalhadoras do CEFAI, presentes no Fórum de julho.

Nesta proposta de pesquisa realizo um mapeamento que não é estático e está sujeito aos movimentos do Fórum na articulação de uma rede que é viva. Considerando os efeitos do pesquisar e da interferência desse ato sobre os processos, os ideais das ciências naturais (objetividade, neutralidade e imparcialidade do conhecimento) não foram contemplados, configurando-se como um outro modo de produzir ciência e conhecimento. Para registrar as experiências vivenciadas no campo foi utilizado um diário de campo e um gravador.

A intensão dessa metodologia é dar visibilidade aos processos do cotidiano dos serviços e à produção dessa rede viva e seus movimentos, captando a dimensão micropolítica. Faço citação de Feuerwerker (2014) para poder elucidar como foi pensado esse processo:

A micropolítica, entendida como o plano molecular em que se efetuam os processos de subjetivação a partir das relações de poder, seria o plano a ser analisado. Por isso mesmo estudar o cotidiano da produção do mundo é uma opção forte - que possibilita ir para o campo mais em aberto, com menos a prioris, mapeando a quente como, em cada território, vão se fabricando as relações, seus limites, suas possibilidades. Esse olhar investigativo aplica-se a todas as áreas. No campo da 
saúde, por ser este um processo que se produz em ato, essa opção torna-se mais importante ainda. (FEUERWERKER, 2014, p.37)

Fiz o convite às participantes de construirmos juntas a pesquisa nesse espaço, a partir disso constituir-me enquanto pesquisadora, com a intenção de produzir um lugar não de pesquisadora-estrangeira, falando outra língua e olhando os processos de fora, ou uma pesquisadora que coloca as pessoas como objeto dos experimentos em situações controladas e com suposto afastamento das afecções e interferências que o campo produz. Mas sim uma pesquisadora-trabalhadora, uma pesquisadora in-mundizada, apropriando-me de um termo utilizado por ABRAHÃO e col. (2014), misturada com as participantes do Fórum, construindo juntas os processos. Fui evidenciando a intenção de dar visibilidade para essas produções e invenções a partir do mapeamento dessa rede que estamos tecendo com muito cuidado e esforço, juntas.

Uma referência adotada foi GOMES e MERHY (2014, p.17) que dizem de certos modos de pesquisar em que "A intervenção na pesquisa não pode vir como vigilância, ou como revelação do oculto. A pesquisa deve operar nas afecções, lugar de intercessor”. Desse modo, fui cuidando para que o meu lugar de pesquisadora possibilitasse rede e diálogo, onde a produção de conhecimento fosse a partir da minha relação com os sujeitos da pesquisa, para que ambos pertencêssemos a um mesmo processo.

Ainda inspirada nesse modo outro de fazer pesquisa, cito o trecho a seguir como estruturante para a produção do campo.

\footnotetext{
Entretanto, podemos reconhecer outros caminhos e modos de produção de conhecimento que incluem o pesquisador e objeto em um mesmo processo, indo além em uma produção intrínseca e intercessora. Pesquisador/objeto não se diferenciam na construção e no fazer investigativo. $O$ resultado deste processo costuma reverberar e ecoar em várias direções, produzindo efeitos e diferentes regimes de verdades que não necessariamente produzem certezas e categorias de descrição de termos sobre o objeto pesquisado, mas novas perguntas e reflexões sobre o próprio objeto. Ou seja, não só produzem novas visibilidades e dizibilidades como também engendram processos inusitados de subjetivação, com a criação de outros sentidos no próprio processo instituinte da pesquisa. (GOMES, 2014, p.25)
}

O campo de pesquisas foi descrito nos meses de encontro do Fórum. Considerando que os profissionais de saúde não estão desterritorializados, coexistem diversos projetos de saúde, evidenciados nas diferentes falas dos Fóruns. Identificamos alguns modos de conceituar e pensar a rede de cuidado para posteriormente produzir diálogo com a literatura. 
As frases estão diferenciadas por cores, fazendo referência às diferentes pessoas que contribuíram para o Fórum, cujas falas representam ideias e conceitos que ilustram como operamos essa rede de cuidados da pessoa com deficiência na Freguesia do Ó e Brasilândia. Em preto ficam algumas descrições minhas ou síntese de diálogos produzidos por diversas personagens, onde não é possível destacar somente uma interlocutora. Alguns conceitos que permeiam os campos de conhecimento de cuidado em saúde da pessoa com deficiência e da saúde coletiva são evidenciados em caixa alta.

As transcrições do Fórum resultaram em um grande volume de falas. Então, optei por destacar algumas que no meu entendimento apresentavam maior relevância para as discussões, mas cuidando para não deixar de trazer todos os temas abordados. Trago as falas reescritas e em formato de discurso indireto. $\mathrm{Na}$ intenção de manter o conteúdo das falas utilizo muitos dos termos utilizados pelas participantes e em alguns momentos faço citação direta das transcrições do Fórum, que as sinalizo entre aspas e em itálico. Apesar da alinearidade das discussões e falas prejudicarem as descrições e o entendimento, eu fiz a opção de mantê-las desse modo para não prejudicar o conteúdo.

Como o Fórum de novembro configurou-se diferente e as falas foram coletivas com compartilhamento de ideias, eu optei por não fazer a separação por cores.

\section{1 - FÓRUM DE JULHO}

O encontro foi na STS FÓ/Brasilândia, localizada no mesmo prédio do CER FÓ. Estavam presentes o CEFAI (Centro de Formação e Acompanhamento à Inclusão, da Secretaria Municipal da Educação) e trabalhadoras da saúde, tanto da STS Freguesia do Ó e Brasilândia, quanto da STS Casa Verde, Cachoeirinha e Limão, representantes dos NASF, UBS, NIR Maria Cecília e CER FÓ.

Ela apresentou a pauta que se tratava da discussão do conceito de DEFICIÊNCIA e REABILITAÇÃO, ressaltou a necessidade de alinharmos nossos entendimentos sobre os mesmos e fez o convite para que cada um falasse o que entendia por DEFICIÊNCIA e REABILITAÇÃO. Pontuou que isso é muito vivo na nossa PRÁTICA e nossas ações são pautadas por esse entendimento, considerou que o conceito de DEFICIÊNCIA é um termo em 
evolução. Ressaltei que há muitas disputas de modelo (MODELO BIOLÓGICO, MODELO SOCIAL, MODELO BIOPSICOSOCIAL).

Falei de um texto que havia lido sobre os MOVIMENTOS "DE" e "PARA" PESSOAS COM DEFICIÊNCIA, citei o Movimento de VIDA INDEPENDENTE que está presente em uma tese ${ }^{4}$ de doutorado. Ressaltei que percebi que o modo de escrita de cada MOVIMENTO é diferente, assim como diferem os termos e conceitos utilizados por um e por outro. Nos movimentos de PESSOAS COM DEFICIÊNCIA diferenciam DEFICIÊNCIA e INCAPACIDADE, pontuei que outras publicações também fazem essa diferenciação e que as BARREIRAS recebem lugar de destaque por considerarem que é na interação com as mesmas que vivenciam a DEFICIÊNCIA. Ressaltei que há um histórico importante de militância das pessoas com deficiência e que há diversos Centros de VIDA INDEPENDENTE (CVI) no Brasil. Na tese citada, foi desenvoldio o conceito de AUTONOMIA e busca o entendidmento do CVI sobre VIDA INDEPENDENTE, conceito fundamental para eles. Pontuei que diversos textos fazem a retomada histórica da DEFICIÊNCIA, mas que acreditava que não seria necessário retomar no Fórum, porque já houve anteriormente um curso a respeito disso no TERRITÓRIO.

Ela problematizou que o CVI surge nos Estados Unidos, ou sofreu influência americana, e por isso conceituam a INDEPENDÊNCIA diferente de como acontece aqui no Brasil. Nos Estados Unidos fazem em uma perspectiva do consumo, "eles falam muito da independência, mas com direito, com muitas aspas aí, 'ao consumo da independência'. Ela usou o exemplo da cadeira de rodas que a gente fornece pelo SUS no entendimento que é parte do atendimento em REABILITAÇÃO., e que nos Estados Unidos há o direito ao consumo da cadeira de rodas, "então, acho que tem uma diferença ai". Considerou que no Brasil a legislação está pautada no direito da PESSOA COM DEFICIÊNCIA como CIDADÃ, na perspectiva dos DIREITOS HUMANOS. Ressaltou a necessidade da tecnologia assistiva para a AUTONOMIA, mas pontuou que este conceito é diferente em cada lugar do mundo, apresentando princípios diferentes. Enfatizou que por outro lado a tecnologia eventualmente

\footnotetext{
${ }^{4}$ Se trata da tese de doutorado da Mariana Prioli Cordeiro, intitulada: "Nada Sobre Nós Sem Nós: Os Sentidos de uma Vida Independente para os Militantes de um Movimento de Pessoas com Deficiência”. Orientada pela Prof $^{\mathrm{a}}$. Dr ${ }^{\mathrm{a}}$. Maria Cristina Gonçalves Vicentin, pela Pontifícia Universidade Católica (PUC-SP)
} 
se torna um nicho de mercado, como bengalas de cegos que reconhecem cores. Falou das diferenças entre o MODELO BIOLÓGICO e o MODELO SOCIAL de REABILITAÇÃO.

Manifestei concordância com a colocação anterior e também falei do estranhamento em relação à isso, mas pontuei que gostaria de trazer outras coisas da tese citada, dentre elas, a VOZ dada às PESSOAS COM DEFICIÊNCIA, que expressa as suas vivências. Citei que uma participante da pesquisa relata que ficava trancada no fundo da casa quando os pais recebiam visita e diziam que era para poupá-la, porque as pessoas olham com estranhamento e poderia ser constrangedor para ela. Em outro relato, uma outra mulher descreveu que era colocada no primeiro andar da casa, para que não conseguisse sair sem a permissão dos pais, então ela jogava a cadeira de rodas escada abaixo, descia os degraus se rastejando e ia para a rua. Ressaltei que isso ia dizendo de um histórico de LUTA, de como foi acontecendo e como as disputas foram se dando. Em diálogo, uma participante do Fórum falou da superproteção da família que produz EXCLUSÃO e enclausuramento e que apesar de ainda acontecer, diversas mudanças ao longo dos anos pressionavam para uma postura diferente.

Nesse sentido, fez um relato do período das ESCOLAS ESPECIAIS, falou sobre uma dada escola onde as SALAS ESPECIAIS ficavam no mesmo prédio das REGULARES, mas havia uma rampa as separando. Quando as crianças com DEFICIÊNCIA tinham a oportunidade de cruzar a rampa para o outro lado "isso era a glória para elas" "e era normal, e a gente nem se ligava disso", e pontuou que as maiores BARREIRAS hoje são as ATITUDINAIS.

Fez a indicação do vídeo da Secretaria Nacional de Direitos Humanos sobre a história e militância das PESSOAS COM DEFICIÊNCIA no Brasil, descreveu que o vídeo é todo ACESSÍVEL em libras, português e áudio descrição. Citou o lema desenvolvido pelo movimento "DE” PESSOAS COM DEFICIÊNCIA "Nada Sobre Nós Sem Nós".

Retomei o texto anteriormente citado e trouxe novamente as falas das PESSOAS COM DEFICIÊNCIA, que diziam querer sair nas ruas, mostrarem-se, serem vistos, porque julgavam ser necessário isso acontecer, em decorrência do estranhamento das pessoas quando veem PESSOAS COM DEFICIÊNCIA, em um entendimento que isso reforça a postura dos pais de colocar os filhos no fundo da casa. Falei de um outro texto, onde há relatos semelhantes de pessoas com deficiência. Pontuei que a falta de convívio com pessoas com deficiência faz com que as outras pessoas não saibam como lidar com a deficiência, por isso produz estranhamento. 
Problematizou que as PESSOAS COM DEFICIÊNCIA são muitas vezes infantilizadas e descredibilizadas. Trouxe uma cena em que estava almoçando com um amigo cadeirante, o garçom se dirigiu a ela perguntando o que ele iria comer, ela respondeu que perguntasse a ele. Ela direcionou a discussão para as BARREIRA e descreveu que são SOCIAIS, ATITUDINAIS, ARQUITETÔNICAS, CULTURAIS e tornam a vida das pessoas mais excludente e "limita muito mais a vida plena". Considerou que as PESSOAS COM DEFICIÊNCIA são destituídas de AUTONOMIA, DESEJOS e ESCOLHAS. Então, ressaltou que é necessário com a nossa prática investir as pessoas de AUTONOMIA e poder de escolha. Outras pessoas dialogaram com essa fala.

Falei da minha EXPERIÊNCIA na leitura de falas de PESSOAS COM DEFICIÊNCIA, ressaltei que sendo fisioterapeuta e tendo sempre trabalhado com PESSOAS COM DEFICIÊNCIA, eu pensava e suponha diversas coisas, mas ler as falas deles, das vivências deles, trouxeram "coisas das quais eu nunca tinha pensado, e nem poderia supor de como isso era para eles". Foi nesse mesmo sentido a minha EXPERIÊNCIA com o Congresso da Rede Unida, uma das apresentações foi em libras, com uma TRADUTORA para o português falado. Pontuei que por estarmos habituados ao processo inverso, isso me provocou estranhamento, pois eu não sabia se olhava para a apresentadora ou para a TRADUTORA. "Esse foi um outro deslocamento importante, porque às vezes a gente está em uma situação e não vivencia o que eles vivenciam”.

“É uma FALA DE LUGAR mesmo. Porque tem muito umas dinâmicas, coloca a venda no olho, aí você vê como é, mas isso não significa nada, não é a mesma coisa que eles VIVENCIAM, ficar dois ou três minutos de olhos vendados".

Falou que as PESSOAS COM DEFICIÊNCIA vão cada vez mais PROTAGONIZANDO e vão falar da DIFERENÇA, como diversos SURDOS que não se consideram DEFICIENTES, fazem parte de uma cultura surda e falam outra língua, "e vai puxando uma proposta que é falar da diferença". Nesse sentido, a NECESSIDADE e a proposta de 'reabilitação eterna', como se as PESSOAS COM DEFICIÊNCIA fossem 'não saudáveis' deixa de fazer sentido. Ressaltou que as pessoas são DIFERENTES e isso se torna LIMITAÇÃO ou não a partir da interação com as BARREIRAS, ou com os FACILITADORES. Nesse sentido, pontuou que "não estamos falando em 'reabilitação eterna" e que as pessoas são DIFERENTES umas das outras, por isso a importância de diminuir as BARREIRAS para que todos possam conviver de maneira mais INCLUSIVA. 
Problematizou que isso direciona para uma MUDANÇA SOCIAL, onde a pessoa não precisaria alcançar a NORMALIDADE, "alcançar para SER". "E acho que é isso que vai fazendo a REABILITAÇÃO estar sempre em construção". "Como a gente vai RESIGNIFICANDO cada vez mais como essas pessoas possam estar junto, não é a pessoa, mas é como a gente muda o ENCONTRO com essa pessoa para que ela possa PARTICIPAR também".

Duas falas dialogaram com a RESIGNIFICAÇÃO, uma pontuou a importância para a vida das pessoas. A outra problematizou que tem a ver com os profissionais: "Q $\mathrm{Q}$ uando a gente pensa em um outro conceito de DEFICIÊNCIA, a gente tem que pensar em um outro conceito de REABILITAÇÃO, porque são coisas correlatas, e ai a gente vai pensar na REABILITAÇÃO só junto da pessoa ou a gente vai pensar no ENTRE?"

Nas falas das trabalhadoras da educação apareceu a insegurança na manipulação das crianças com DEFICIÊNCIA FÍSICA. Destacou a sua insegurança para colocar uma dada criança na cadeira, porque poderia machucá-la. Diversas falas dialogaram a respeito dessa relação entre educação e saúde, foi reforçado os nossos LIMITES e acolhido a angústia das professoras e trabalhadoras da educação.

Diversas falas disseram que há necessidade de ouvir o USUÁRIO nesse processo, considerando que a DEMANDA deles diversas vezes está para além das LIMITAÇÕES que enxergamos: "a gente quer corrigir e fazer da melhor forma", mas releva que essa pode não ser a expectativa dos mesmos. Ela falou da sua EXPERIÊNCIA enquanto fisioterapeuta, que um dado USUÁRIO fez ela pressupor diversas coisas, mas ele a surpreendeu dizendo que "só queria cair menos quando joga futebol". No atendimento de um USUÁRIO com paralisia cerebral, que ela acreditava que estava lá em uma expectativa comum, a fala dele foi fazendo ela perceber que era muito além disso. Ele foi falando da relação com seu CORPO "dizendo eu tinha aflição na minha infância porque o meu CORPO não respondia ao que eu pensava, que ele estava trancado e ele não fala de um trancar de pai e mãe, de família, de sociedade, mas o trancar de um CORPO mesmo". Ela também fala sobre quando a pessoa se insere em uma ATIVIDADE e que a gente quer ir moldando, mas às vezes não é isso que eles querem "só querem estar ali".

Ela falou sobre o sobrinho, que é uma criança e sempre falava do 'melhor amigo' da escola. No aniversário dele quando o 'melhor amigo' chegou, ele avisou a mãe que o mesmo precisava de 'uma ajudinha'. Foi quando perceberam que o 'melhor amigo' apresentava 
DEFICIÊNCIA FÍSICA, não conheciam a criança anteriormente e nas falas do sobrinho a DEFICIÊNCIA nunca houvera aparecido como uma característica do 'melhor amigo'. Ela foi dizendo de como as coisas estavam diferentes, que na sua época era mais difícil ver PESSOAS COM DEFICIÊNCIA. Nisso, foi falando de uma percepção diferente das crianças pontuando que nós adultos é que olhamos as pessoas na perspectiva das FALTAS e das DEFICIÊNCIAS.

Ela considerou na sua fala que o PRECONCEITO produz EXCLUSÃO e LIMITA a vida das pessoas. "Uma criança muitas vezes ela é CEGA e ela vai se tornando muitas vezes um autista, porque essa criança não é olhada, e ela só é CEGA e as pessoas não chegam perto dela, não interagem com ela, por ela ser CEGA, então vai se tornar uma pessoa com outros problemas". Conclui falando da importância de olhar sem preconceito para as pessoas, mas reforça que achava necessário ter cuidado para não machucar as crianças com deficiência física no momento de fazer as transferências, porque como educadora elas não sabem como podem manipular as crianças ou não.

Ela falou que se a pessoa está disponível para o ENCONTRO com as crianças, elas respondem mesmo em uma comunicação não-verbal e expressam o que querem, assim como se está machucando ou não. Dialogou com a fala anterior, falando que há uma ligação com uma história de retirada de AUTONOMIA, porque as PESSOAS COM DEFICIÊNCIA vão sendo destituídas de AUTONOMIA, DESEJOS e ESCOLHA. Pontuou que trabalhar com criança é difícil, mas investi-los de PODER de escolha é importante para trabalhar com "autonomia em um momento ótimo deles", pois frequentemente cerceamos a liberdade deles.

Retomou a questão do preconceito, dizendo que o PRECONCEITO vai virando PROGNÓSTICO, "vai virando todos os cegos são iguais, todos os surdos...". Para exemplificar ela traz o caso de uma criança SURDA que a mãe diz que "todo SURDO é assim", mas considerou que na realidade "a menina tem uma puta questão comportamental" e que não tem só relação com a DEFICIÊNCIA AUDITIVA.

Falou das dificuldades que as crianças da escola apresentam para conseguirem ACESSAR a REABILITAÇÃO e receber cadeira de rodas, pois as filas de espera demoram bastante. Contou sobre um movimento de querer produzir prancha de comunicação alternativa, por outro lado, falou que não achava que seria adequado. Contou das adaptações que foram feitas pelas estagiárias da educação na cadeira de rodas de uma criança e que receberam críticas da fisioterapeuta. Exemplificou como estabelece diálogo com as crianças, 
mesmo as que não falam, que frequentemente pergunta aos pais sobre a casa, o fim de semana, a rotina, trazendo elementos conhecidos para possibilitar conversa com as crianças, que produzem respostas não verbais a esse diálogo.

Diversas falas afirmaram a importância do VÍNCULO estabelecido entre a professora e os alunos, assim como a POTÊNCIA desse ENCONTRO, que produz comunicação efetiva, mesmo com crianças que não falam. Desse modo, ressaltamos a importância da integralidade e do trabalho em conjunto para possibilitar maiores ganhos aos usuários. Evidenciamos os limites enfrentados na saúde como limitação técnica, limite no estabelecimento de VÍNCULO com os USUÁRIOS, tempo curto de terapia, famílias que não se envolvem no tratamento, todos elementos importantes para a possibilidade de reabilitação. Falei da necessidade de estarmos juntas, produzir rede e nos apoiarmos para poder cuidar das crianças.

Contou uma história da REABILITAÇÃO, sendo o pós-guerra um propulsor da criação de grandes centros de reabilitação, por causa dos heróis de guerra, que precisaram ser REABILITADOS, pois foram considerados pessoas muito importantes. Destacou que esses Centros de Reabilitação foram criados em vários países, tinham um certo padrão e dispunham de tecnologia, mas como nos países de TERCEIRO MUNDO não havia as mesmas condições, a REABILITAÇÃO foi pensada envolvendo a COMUNIDADE e virou um modelo a REABILITAÇÃO BASEADA NA COMUNIDADE, que passou a ser indicado pela OMS por considerar que apresenta uma riqueza, que o outro modelo não apresentavam. Pontuou que nesse modelo a REABILITAÇÃO era baseada na INCLUSÃO e possibilitava o envolvimento de mais pessoas. Analisou que nesses outros formatos há uma "superpotência" a partir da RELAÇÃO. Por outro lado, "o que é falar para uma pessoa que ela vai ser tratada no CER ou na AACD!?".

Dialogando com a provocação dela, falei que vai sendo produzido, socialmente, que algumas pessoas têm mais condições de intervirem em dadas situações. Então, descrevi minha EXPERIÊNCIA com o grupo de dor crônica, onde ressaltei a observação de que o usuário ia sendo destituído de PODER e não se sentia autorizado a INTERVIR no próprio CORPO. Nesse grupo de dor, em conjunto com a psicóloga da UBS, trabalhamos para POTENCIALIZAR as pessoas para INTERVIREM no próprio CORPO, e no CUIDADO DE SI, em um movimento de desconstruir que as dores só fisioterapeutas podem "tratar".

Foi feita uma provocação: "O que é REABILITAÇÃO? Como que a gente PRATICA isso? Como que isso está presente na unidade?" 
Depois de certo tempo de silêncio algumas falas dialogaram com essa provocação.

Falou da padronização do que é NORMAL, e ressaltou o LIMITE TERAPÊUTICO. Problematizou que algumas pessoas "vão andar de outra forma", "falar de outra forma". Então, fez outra provocação "e nesses casos?"

Ela disse que nós e as famílias buscamos esse PADRÃO e questionou se as frustrações apareceriam como decorrência dessa busca. Problematizou, em diálogo com a fala anterior, que a partir disso as pessoas começam a olhar para a DIFERENÇA, assim como para as possibilidades dentro dessa condição.

Falou do caso de um bebê com agenesia de membros e que as terapeutas não souberam como fazer alguns testes de avaliação, porque eram pensados para crianças que possuem os 4 membros e isso dificultou a avaliação. Também não souberam como segurar a criança, e perguntaram à mãe: "Como você segura seu filho?” Problematizou que não sabiam diversas coisas e que seria importante perguntar. Considerou também que a REABILITAÇÃO deve envolver toda a família, porque as crianças estão em desenvolvimento. Usando esse caso para exemplificação pontua que foi necessário darem apoio para as frustrações da mãe, assim como envolver os irmãos nas terapias.

Fomos caminhando a discussão trazendo a relação com as FAMÍLIAS. Uma participante falou da participação em um curso da APAE, onde falaram sobre a sala de ESTIMULAÇÃO PRECOCE dos bebês que era ao lado da oficina de adolescentes e adultos. Em decorrência disso houve uma solicitação dos pais dos bebes para separassem seus filhos das pessoas mais velhas, porque não queriam ver como os filhos ficariam no futuro. A partir desse relato ela problematizou que não se sentia no direito de dizer onde a criança iria ou não chegar, até porque não sabemos, apesar de alguns casos nos darem pistas a respeito.

Ela falou do caso de um amigo com sequela de Poliomielite, que usava muletas canadenses. Ela contou uma descrição feita por ele, de um certo dia que ele considerou um dos mais felizes de sua vida, "ele teve um insight". Ele havia comprado uma cadeira de rodas e a usava aos fins de semana. Em um domingo estava com a filha que pedira um coco, ele comprou o coco e colocou no colo, deslocando-se com a cadeira de rodas conseguiu levar à filha. A partir disso decidiu que queria locomover-se daquela forma e não mais com o auxílio de muletas. Ela disse que se lembrava de outros casos de pessoas que tiveram deslocamentos importantes a partir de saídas para esses outros espaços, que são diferentes dos espaços onde dizemos qual a melhor forma de andar ou de fazer as coisas. 
Falei como a nossa PRÁTICA deveria ajudar a potencializar as pessoas a terem condições mais adequadas de fazer ESCOLHAS e assim poderem viver do modo que escolherem. Isso poderia possibilitar que a pessoa tenha mais AUTONOMIA para fazer aquilo que deseja. Pontuei que há momentos na vida que é necessário alguém para ajudar "e que bom que tem isso". Falei da necessidade de trabalharmos em REDE com a educação, para nos ajudarmos e para diminuir as angústias, assim como para pensarmos em REDE o CUIDADO do USUÁRIO.

Em diálogo, ela falou que tem um trabalho nosso que é de ordem política, estar JUNTO, para poder pensar quais defesas a gente tem com as diversas situações, como quando os usuários vão pegar o ônibus e o motorista não para. Destacou a relevância de criar essas situações para estarmos JUNTO e fazermos JUNTO com os usuários. Descreveu uma cena de uma mulher com DEFICIÊNCIA VISUAL que foi ao supermercado e que na fila do caixa foi indaga por outra mulher dizendo que ela não deveria estar lá sozinha. "Porque o exercício político do enfrentamento das BARREIRAS ATITUDINAIS, das BARREIRAS que são de ACESSO À CIDADE e dessas coisas que escapam extremamente ao nosso CUIDADO, seja na escola, seja em REABILITAÇÃO, mas que é do dia a dia e é o que faz as pessoas não fazerem as coisas, por mais 'HABILITADAS' que elas estejam [...] mas ele continua não fazendo coisas porque ele não é igual ele era antes, e não é mesmo e nem vai ser e não tem a ver só com esse CORPO, né!? Então de como é que a gente pode pensar na REABILITAÇÃO nos espaços de vida, construindo POLÍTICA, fazendo essa política assim, para além da legislação, mas fazer valer coisas que já são direitos e tem a ver com essa situação das pessoas e que vão acontecendo o tempo inteiro essas coisas né!?”.

"Se a BARREIRA está aí, então a proposta de REABILITAÇÃO está ai".

"Não dá para ficar só no consultório, né!?"

Uma professora falou de uma aluna dela que não gostava de usar andador e chorava quando o usava, mas a fisioterapeuta insistia muito nesse uso apesar da mãe e da menina preferirem a cadeira de rodas. Mesmo contrariando a fisioterapeuta a menina começou a usar a cadeira de fim de semana, então, junto com a mãe fez a escolha de usá-la como meio de locomoção. A educadora relatou que a menina ficou muito mais feliz depois disso e mesmo quando continuou preferindo a cadeira de rodas. Então, ela problematizou que ficava em dúvida sobre até onde deveria insistir, tanto pedagógica quanto terapeuticamente, de que "esse é o melhor jeito". 
Algumas pessoas falaram que esperavam que ela continuasse com essa questão, porque não havia uma resposta pronta.

Nesse sentido, retomamos a conversa sobre VÍNCULO, POTÊNCIA DO ENCONTRO, ESCUTA AO USUÁRIO, CO-RESPONSABILIZAÇÃO e CUIDADO. Ela ressalta a importância de trabalhar junto com a POPULAÇÃO. Em diálogo, ela falou sobre mães que cobravam da escola que estimulassem as crianças, mas que durante as visitas domiciliares as professoras observavam que a criança ficava em um quarto fechada assistindo TV e sem outros tipos de estímulo. Pontuou que "não é se eximir de responsabilidade", mas realçou a necessidade de CO-RESPONSABILIZAÇÃO da família.

Reafirmou que na Atenção Básica também é feito REABILITAÇÃO, “não é só nesse pedacinho aqui no CER”, enfatizou que é bastante fértil aquilo que está presente na Atenção Básica.

Falaram do Centro Paraolímpico e que o mesmo oferta transporte e alimentação. Esclareceram que e ao contrário do que pensávamos era direcionado para qualquer pessoa com DEFICIÊNCIA e não somente às que possuem uma HABILIDADE EXCEPCIONAL. Dando continuidade à conversa, uma pessoa falou sobre como o esporte modificou a vida do amigo que ficou paraplégico.

Para concluir foi feita a leitura do conceito de REABILITAÇÃO do Ministério da Saúde.

3.1.2 - Propostas para o próximo Fórum

1. Discutir o trabalho para pessoas com deficiência em uma perspectiva intersetorial, considerando a dificuldade de inserção dessas pessoas.

1. Convidar pessoas de lugares que não são da saúde como o CECCO, CEU, esporte e lazer, cultura...

2. Trazer o mapeamento dos lugares visitados, o que já havia sido programado. 
O encontro foi na STS Casa Verde, Cachoeirinha e Limão. Iniciamos retomando as discussões do Fórum anterior, pois diversos presentes não estavam no encontro de julho. Conversamos sobre a participação no Fórum que não vinha sendo constante e discutimos como nos organizaríamos de modo que pudéssemos avançar nas pautas e discussões. Uma proposta foi reforçar a importância das unidades tentarem garantir que uma pessoa fícasse como referência para frequentar os ENCONTROS. Reforcei meu compromisso de fazer os relatos das reuniões para ser um documento que facilitasse esse processo de retomada das discussões e combinados.

Fizemos a retomada da conversa sobre DEFICIÊNCIA e REABILITAÇÃO e diversas CENAS foram trazidas para possibilitar que as discussões dos conceitos fossem ancorados em CASOS concretos, dando VISIBILIDADE ao modo como vamos operando o conceito de DEFICIÊNCIA e como isso atravessa as nossas PRÁTICAS, assim como o que vem sendo pensado sobre a REABILITAÇÃO e o CUIDADO para PESSOAS COM DEFICIÊNCIA nos TERRITÓRIOS. A fala a seguir introduziu a conversa.

"Se a gente tem esse compromisso com o TERRITÓRIO, se a gente vai conseguindo entrar nesses espaços, acho que vai fazendo um movimento que daqui a pouco a gente não vai precisar mais fazer esse AGENCIAMENTO, acho que é um pouco do que tem a ver com o que a gente estava falando de consenso de DEFICIÊNCIA e REABILITAÇÃO, porque a gente pode entender também a REABILITAÇÃO de uma maneira muito mais ampla, que inclui esses AGENCIAMENTOS inclusive. Quando a gente fala que conceito de PESSOA COM DEFICIÊNCIA ele não está no ORGANISMO, mas está justamente nessa RELAÇÃO com essas BARREIRAS ou com os FACILITADORES da PARTICIPAÇÃO das pessoas, né!? Então por isso que a gente foi por esse caminho, do quanto a gente consegue enquanto ATORES né!? dessa proposta de REABILITAÇÃO, conseguir atuar nas BARREIRAS, para essas pessoas poderem estar nos lugares e acho que poderem sair desse espaço de saúde e da REABILITAÇÃO como exclusivo, o espaço de circulação dessas pessoas exclusivo são os espaços de saúde e aí aquela coisa, de que a pessoa nunca vai andar a cavalo, sempre vai fazer equoterapia, tudo vai ser uma terapia. Acho que foi por esse caminho que a gente foi um tanto no Fórum passado, agora não sei se a gente falando assim está totalmente desconexo, porque a gente veio fazendo um percurso."

Fomos trazendo a importância de que outros ATORES entrassem em CENA para pensar o CUIDADO devido à complexidade desse processo. Avançar na 
INTERSETORIALIDADE foi considerado importante para que pudéssemos construir possibilidade de circulação das PESSOAS COM DEFICIÊNCIA em espaços fora da saúde, mas também problematizamos o nosso modo de operar dentro da saúde. Discutimos o CUIDADO em REABILITAÇÃO para além dos serviços especializados e dos profissionais especialistas, colocando em evidência a POTÊNCIA do CUIDADO mesmo em outros espaços como a Atenção Básica, privilegiados para fazer ESCUTA e ofertar PRÁTICAS CORPORAIS, possibilitando o trabalho da RELAÇÃO dos USUÁRIOS com o próprio CORPO. Trouxe uma discussão feita pelo CER, onde consideraram ser fundamental trabalhar com elementos de conscientização corporal e autopercepção para possibilitar que os usuários recebessem as orientações de outro modo e que fossem melhor aproveitadas. Problematizou que algumas pessoas apresentam "um certo distanciamento do CORPO que por si só já é patológico" e é preciso trabalhar isso. Nesse sentido, fomos discutindo como vamos reafirmando isso no modo de CUIDARMOS, que em diversos momentos impõe e produz DEMANDAS. Desse modo, vamos dizendo ao USUÁRIO o que ele pode ou não e reflete na RELAÇÃO deles com o PRÓPRIO CORPO, então, produzimos essa NECESSIDADE de "reabilitação eterna".

Retomou o lema "Nada Sobre Nós Sem Nós", assim como a história dos movimentos de PESSOAS COM DEFICIÊNCIA que foi bastante discutido no Fórum anterior. Ressaltou a privação de espaço de fala que as pessoas com deficiência historicamente sofreram. Então, esse movimento reforçou que eles querem falar por eles mesmos.

Falei da CAPTURA que a saúde produz com uma certa lógica que se expressa tanto no modo de operar dos profissionais como nas NECESSIDADES manifestas pelos USUÁRIOS, que frequentemente produzem o mesmo discurso. Ela falou da importância de transitar por outros lugares por possibilitarem outras VIVÊNCIAS e outras possibilidades de estar no mundo, que poderiam fazer mais sentido para os sujeitos e para os modos de vida que escolhem viver. Alguns CASOS discutidos foram exemplificando que há diversas possibilidades de pensar o CORPO e a DEFICIÊNCIA, que vão desde a escolha dos sapatos à escolha do modo de se locomover. Nesse sentido, ela discutiu a necessidade de promover esses espaços de circulação fazendo JUNTO com os USUÁRIOS, como idas ao parque e andar de ônibus.

Retomou um CASO do Fórum anterior do amigo que fez diversas cirurgias para conseguir ficar em pé e andar com muletas. No entanto, em um domingo ele saiu usando 
cadeira de rodas junto com a filha que pediu um coco. Ele conseguiu comprá-lo, colocar no colo e levar a ela, o que seria possível usando muletas. A partir desse momento ele decidiu que queria se locomover de cadeira de rodas, contrariando o modo como majoritariamente a REABILITAÇÃO é pensada. Ela problematizou que vamos acreditando que quanto menos a pessoa precisa do dispositivo, maior a independência, e que então andar seria supostamente melhor a usar cadeira de rodas.

Um outro caso por ela apresentado foi o de uma fisioterapeuta com DEFICIÊNCIA FÍSICA (dupla hemiparesia). Durante a pratica de judô, o professor confeccionou uma órtese para ela, com o material disponível, para que conseguisse fazer uma certa 'pegada' no judô a qual ela apresentava dificuldade em realizar. Isso provocou um DESLOCAMENTO importante, porque ela tinha diversos amigos terapeutas ocupacionais, era fisioterapeuta e nunca pensaram nisso. Esta órtese confeccionada pelo professor de judô também a ajudava em outras atividades na vida. Essa mesma fisioterapeuta sempre usava tênis porque era indicado isso e acreditava que seria o mais adequado, apesar de sempre ter vontade de usar rasteirinha. Um certo dia ela decidiu usar rasteirinha, então, pode perceber que a ajudava mais no equilíbrio do que o tênis, porque era possível sentir melhor o chão e perceber onde estava pisando.

Diversas BARREIRAS DE ACESSO ao transporte público, aos prédios, às ruas e até mesmo às casas foram discutidas, evidenciando como as BARREIRAS levavam ao impedimento da PARTICIPAÇÃO SOCIAL dos usuários, assim como limitava a PRODUÇÃO DE DESEJOS. Nesse sentido, discutimos que OFERTAS inadequadas também poderiam ser produtoras de BARREIRAS. Em diálogo, uma participante falou dos ônibus e motoristas que não paravam para PESSOAS COM DEFICIÊNCIA e que não queriam descer a rampa, mas também ponderou que frequentemente as rampas dos ônibus estão quebradas e há o limite de transportar somente uma cadeira de rodas por ônibus, o que já atrapalhou planos de saídas do CER. Então, considerou que seria preciso fazer algumas negociações para AGENCIARMOS essas saídas, como conversar com os motoristas, saber os horários dos ônibus adaptados, entre outras. Com a sua fala problematizou que temos que ir fazendo esses agenciamentos, porque mudanças maiores demoram um outro tempo "porque acho que se a gente trava aí, por mais reformista que pareça, se não a gente não vai mesmo".

Fomos caminhando a discussão para o PROCESSO DE CUIDADO e pontuando como a complexidade da vida das pessoas, assim como as suas ESCOLHAS, iam causando abalos 
no modo de pensarmos as OFERTAS, a ESCUTA e o próprio CUIDADO. Falou do caso de um USUÁRIO que se "arrastava" e estava ADAPTADO no chão. "Ele está super ADAPTADO" mas ressaltou a expectativa da equipe de saúde que ele sentasse em uma cadeira de rodas e tivesse uma vida, assim como "o quanto choca" ele estar se "arrastando". No entanto, disse que seria inviável nas condições que eles viviam colocá-lo na cadeira de rodas, porque ele era muito grande e residia somente com a mãe. Ela falou que esse caso já foi bastante discutido na unidade e que mobilizava a EQUIPE por anos. Nas discussões foi sendo dito que talvez não fosse um problema a condição dele, discutiram que essa condição talvez possibilitasse mais AUTONOMIA do que a cadeira e que muitas vezes menosprezamos as ADAPTAÇÕES dos usuários.

Uma das participantes do Fórum falou de uma EXPERIÊNCIA em uma dada aula do curso de libras que ela estava fazendo e problematizou que "a gente sabe de todo o debate que existe na COMUNIDADE SURDA, de que a SURDEZ não é uma DEFICIÊNCIA e mais um monte de coisa". Nessa aula uma das alunas questionou o professor, que era SURDO, porque ele nunca quisera usar aparelho auditivo. Ele disse estar bem ADAPTADO e desde criança nunca quis usar, no entanto, essa aluna continuou insistindo nisso. A participante do Fórum ressalta que trouxe esse caso para dizer do quanto é difícil o processo de PRODUÇÃO DE CUIDADO com o USUÁRIO, "porque se colocar nesse LUGAR é sempre ativo, o tempo todo a gente tem que abrir mão de questões que são morais e tem a ver com a gente e não com o OUTRO, e também com uma técnica que é positivista, é fechada, e ai se colocar no lugar de OUVIR O OUTRO”.

$\mathrm{Na}$ minha fala pontuei que as pessoas vão se ADAPTANDO a dadas situações bem difíceis, mas que para algumas pessoas isso ocorre em decorrência da ausência de OFERTAS, ou porque estas são inadequadas. Ressaltei que temos diversas deficiências e dificuldade no SUS e apesar de aqui em São Paulo ainda conseguirmos ofertar bastante coisa, vamos tentando construir a saúde pública a duras penas. No entanto, ressaltei que muitas vezes apresentamos LIMITES na nossa possibilidade de fazer OFERTAS e desse modo "tem situação que não é escolha, não é uma opção, é a única possibilidade que a pessoa tem". Desse modo, enfatizei que tínhamos que ESCUTAR e fazer OFERTAS, mas que a escolha não é nossa. Então, devemos CUIDAR para que a OFERTA não imponha uma certa LÓGICA e por isso temos que ESCUTAR. 
Dialogando, ela disse que achava necessário "voltar um pouco" e olhar para o caso do menino que se "rastejava" pela casa. Considerou a necessidade de haver uma ESCUTA QUALIFICADA da atenção básica até a especializada para que diminua a angústia dos profissionais. Então, o pedido e o ENCAMINHAMENTO podem ser elaborados de outra maneira. Do contrário, vão continuar chegando pedidos muito angustiados e sem relação com a DEMANDA DO USUÁRIO. Ela apresentou o caso de um homem que também se "rastejava" dentro de casa e provavelmente sofreu lesão medular há muitos anos, apesar dele e da família apresentarem dificuldade em fornecer detalhes sobre o ocorrido. Ele caiu da escada em um dia que estava embriagado e ficou internado no hospital, o mesmo não consegue andar desde então e isso já faz aproximadamente 30 anos. No modo como descrito pela fisioterapeuta ele sobe e desce os degraus de casa "arrastando-se". A equipe de saúde havia solicitado uma visita da fisioterapeuta porque ele se arrastava pela casa inteira e precisava de uma cadeira de rodas. A casa possuía vários andares "aquelas casas do Icaraí, que cada andar é um cômodo". A fisioterapeuta disse que quando foi ouvi-lo, ele não quis cadeira de rodas e disse que já teve várias, mas que nunca se ADAPTOU. Ele apresentava diversas deformidades nos membros inferiores, "talvez por uma DEFICIÊNCIA DE OFERTAS lá atrás". No momento da visita ele manifestou o DESEJO de querer alguém para conversar, porque se sentia muito sozinho e era esse seu PEDIDO, não queria cadeira de rodas. Ela ressaltou que se "a ESCUTA é um pouco mais atenta tira essa angústia de quem vê essas situações".

O caso foi puxando a discussão sobre OFERTAS em que a angústia e o DESEJO presentes são do profissional e não do usuário, e que fazemos um atropelamento em nome de um SABER. Ressalta que há pessoas que não estão preparadas para dizer o que querem como as crianças, mas não só, e isso é uma questão, porque precisamos dar apoio para as pessoas se sentirem fortalecidas e terem condições de fazer suas próprias ESCOLHAS. Por outro lado, em relação às crianças é difícil ouvir um não, porque elas ainda não têm maturidade para isso.

Falei sobre o caso de um usuário cadeirante cuja DEMANDA era ficar em pé, pois não queria ver sempre as pessoas de baixo para cima, e para isso se dispunha a passar por diversas cirurgias para correção das deformidades. Ela discutiu que isso tem relação com o valor produzido socialmente, onde é valorado andar e ficar em pé. "Não que seja legal ser deficiente, não é isso, mas talvez daqui há alguns anos não seja um problema olhar as pessoas de baixo para cima". Então, problematizou que não seria um problema não andar e 
estar na cadeira de rodas. Algumas falas dialogaram com esta, dizendo que o ambiente e a família produzem bastante influência no modo como eles lidam com a situação.

\subsection{1 - Outras cenas e casos}

Um USUÁRIO do CER, cadeirante, precisava usar o banheiro e necessitava de ajuda da esposa. No entanto, o banheiro adaptado fica dentro do masculino. A esposa pede ajuda para alguns trabalhadores, que não se sentiam autorizados a ajudar, por serem do setor administrativo. Uma trabalhadora da APD vê a cena e decide ajudar, "eu não sou fisioterapeuta, mas posso ajudar". Fazem uma sinalização que o banheiro está em uso, ela pede ajuda, pergunta "como vocês fazem?" porque não sabia como poderia ajudar. Nesse momento, as fisioterapeutas falaram simultaneamente que muitas vezes a gente também não sabe. Fizemos a discussão sobre ser normal não sabermos e perguntar. Nesse sentido, discutimos que nos colocarmos nesse LUGAR de não saber é importante, porque abre espaço para outras construções com o usuário e com a família. Ressaltamos que não sabemos de várias coisas, mas para além das deficiências técnicas, não sabemos a história das pessoas e o modo como vão lidando com dadas situações. Desse modo, o "não saber" possibilita OUVIRMOS mais e construirmos OFERTAS que façam mais sentido.

O caso de um menino com diagnóstico de distrofia muscular de Duchenne colocou as profissionais em um dilema ético/político. Ele não quer usar a órtese suropodálica para prevenir deformidades, porque gera desconforto. No entanto, a doença é progressiva e ele vai ter uma sobrevida pequena, não vai crescer para poder dizer sobre o uso disso ou não. Desse modo, ao trazer o caso ela problematizou se no PROJETO TERAPÊUTICO dele priorizaria possibilitar bons momentos, ou não insistir no uso da órtese seria negligenciar? Ponderou que não há uma resposta, mas sim uma construção JUNTO com a família e com ele, que estava sendo operacionalizada.

Um grupo de reabilitação no qual as participantes são mulheres de '30 e poucos anos' que sofreram um AVE -elas fumavam e usavam anticoncepcionais- é destacado devido à CONTRA-TRANSFERÊNCIA que esses casos produzem nas profissionais. Nesse sentido, sem negar a necessidade de produzir ofertas e a importância de não negligenciar o USUÁRIO, é problematizado a nossa persistência em produzir OFERTAS, mesmo quando as pessoas não apresentam mais ganhos, quando a REABILITAÇÃO chega no LIMITE. É 
pontuado a necessidade de nos colocarmos em análise, pois com frequência essas questões são nossas. Talvez a pessoa deveria estar transitando em outros lugares, ao invés de insistirmos em algo que não vai mais progredir, deveríamos ir agenciando a participação delas em outros lugares para fora da saúde. No CER os profissionais disseram que usam os espaços de reuniões para PROCESSAREM esses desconfortos.

Ela retomou o caso da físioterapeuta com deficiência física citada anteriormente, mas em outra CENA. Descreveu que ela demorava um certo tempo para cruzar a sala e apresentava algumas limitações físicas. Então, durante as terapias de USUÁRIOS com problemas neurológicos, ela precisava do auxílio dos cuidadores para executar alguns exercícios, o que a princípio parecia uma desvantagem, mas no entanto, tornou-se POTÊNCIA, porque os cuidadores ficavam mais apropriados dos exercícios e desenvolviam mais condições de executá-los em casa, visto que já o faziam durante as terapias. Desse modo, os USUÁRIOS eram REABILITADOS em um tempo mais curto e recebiam alta mais rápido, quando comparados aos usuários cuidados pelos outros fisioterapeutas, onde estes executavam os exercícios. A participante do Fórum pontuou que era um jeito diferente de fazer, e isso nos possibilita aprender a olhar para a DIFERENÇA e não para a FALTA.

Ela discutiu o impacto do DIAGNÓSTICO e do CID $^{5}$ para os USUÁRIOS, que apesar de falarem pouco sobre o sujeito, podem representar "um peso" em suas vidas, modificando as suas RELAÇÕES, assim como o modo que a pessoa se percebe. Exemplifica com o caso de uma menina que foi diagnosticada com $\mathrm{PC}^{6}$ aos 5 anos de idade, anterior ao diagnóstico ela apresentava bom desempenho escolar, bom comportamento e sem nenhuma queixa. A DIFERENÇA em um hemicorpo sempre esteve presente, mas nunca causou impacto na sua vida. No entanto, após o diagnóstico a criança piorou seu desempenho na escola e o seu comportamento. O modo como os familiares passaram a se relacionar com ela também mudou. A fisioterapeuta manifestou que acreditava ser melhor para a criança que a mesma transitasse por algum espaço que não tivesse esse "peso" do diagnóstico. Por outro lado, apresentava medo de negligenciá-la, então, procurou ajuda do CER para discutir o caso, o que a deixou mais tranquila e optaram por encaminhar a criança para algum lugar que ofertasse

\footnotetext{
${ }^{5}$ Código Internacional de Doenças.

${ }^{6}$ Paralisia Cerebral é o termo que se referia à uma patologia, atualmente foi substituído por Encefalopatia Crônica Não Degenerativa (ECNE), apesar de ainda ser bastante utilizado o termo anterior.
} 
atividades que contribuiriam para o seu desenvolvimento, mas que não fosse um espaço da saúde.

"Não dá para viver a existência a partir da falta". Ela ressaltou que pensa a ideia de superação sendo problemática, porque a associam com sucesso em uma perspectiva de conquista individual, o que ignora a nossa capacidade de fazer OFERTAS e as possibilidades de ACESSOS. E ainda coloca no indivíduo toda a responsabilidade pela sua INSERÇÃO SOCIAL “Essa palavra não deveria estar associada à deficiência”. Nesse sentido, a pessoa é quem tem que superar as BARREIRAS e não elas deixarem de existir para que a pessoa tenha condições mais favoráveis de PARTICIPAR e executar tarefas. Desse modo, a SOCIEDADE não precisaria mudar, o que propomos é o oposto disso, é retirar as BARREIRAS.

\subsection{2 - Discussão do mapeamento}

A proposta de fazer rede para além da saúde e de visitarmos os equipamentos de cultura, lazer e esportes da região foi retomada. Discutimos como fazer e com qual objetivo nos aproximaríamos desses espaços. Diversas pessoas contribuíram para essa conversa, olhando sobre planos diferentes. Esse mapeamento foi pensado para construirmos possibilidade de inserção dos usuários nesses espaços, assim como para a efetivação de ações intersetoriais.

Uma pessoa retomou uma proposta antiga de mapeamento, retomada anteriormente diversas vezes, onde o levantamento da rede seria feito, em um primeiro momento, como um todo e não só sobre as pessoas com deficiência, mas com dor crônica também, entre outras demandas.

Outra proposta foi de fazer conversas nos locais que apresentem, ou não, atividades para pessoas com deficiência, indagando sobre como procedem quando chega uma pessoa com deficiência, se apresenta acessibilidade, se há atividades adaptadas. Propõem problematizar se essas atividades para pessoas com deficiência são realizadas em conjunto, ou não, com pessoas sem deficiência e o porquê. Essa visita é pensada como um movimento político, de produzir esses espaços de circulação de pessoas com deficiência.

Problematizam que separar o lugar do 'deficiente' do lugar do 'não deficiente' é ruim. Então, a proposta foi que esse mapeamento fosse um exercício político, de produzir questões 
e agenciar a participação dessas pessoas nesses espaços visitados, não somente fazer o levantamento do lugar e das atividades.

Foi também proposto que essas informações fossem periodicamente atualizadas e compartilhadas. Discutimos se seria só no TERRITÓRIO, ou se expandiríamos. Ficou decidido que neste momento faríamos somente no TERRITÓRIO. A prioridade estabelecida foi de fazer as visitas em lugares públicos e gratuitos, mas o CER trouxe a necessidade de conversar com uma escola de natação privada, que aceita pessoas com deficiência, visto que diversos usuários do serviço têm frequentado esse espaço e parece ser um lugar potente.

Ao final, não foram determinados os lugares que cada serviço visitaria, mas combinamos de trazer no próximo Fórum um lugar que tenhamos conseguindo fazer visita e preferencialmente fazer a conversa sobre a inserção de pessoas com deficiência nesse espaço.

Ficou combinado que o Fórum de setembro também ocorreria na Supervisão da Casa Verde, Cachoeirinha e Limão e a pauta seria o compartilhamento dos locais que os serviços visitassem e foi ressaltado que esse mapeamento seria estabelecido como meta, por ser uma proposta antiga que nunca se concretizara.

\section{3 - FÓRUM DE SETEMBRO}

A fala inicial foi sobre memórias do Fórum de agosto, pontuando que foi um texto feito por mim e relacionado com a pesquisa do mestrado. Ela apresentou um certo estranhamento de ser em primeira pessoa, mas achou importante para retomar o que foi discutido no Fórum anterior e disse que a ajudou. Me propus a continuar fazendo e uma outra proposta foi de pensar nisso enquanto grupo e que cada um ficasse responsável pela memória. Propus usarmos esses textos, talvez outro que eu também poderia escrever sobre o Fórum, para discutirmos no Fórum ou em outra data em que estivessem presentes somente as trabalhadoras da FÓ/Brasilândia. Enfatizei que eu gostaria da participação das pessoas para não ficar só a minha leitura do campo.

Ela pontuou que as falas são de todos "e o que você coloca como memória também ativa em cada um visões e colocações que vão estar aqui, eu acho que isso de fato já acontece". Dialogou com a minha proposta dizendo que poderíamos em algum momento 
parar para fazer essa análise de processo, talvez no fim do ano, mas teríamos que ver o momento mais adequado, pois o Fórum é dinâmico.

Iniciamos a pauta que era trazermos os lugares do TERRITÓRIO que foram visitados. Muitas se manifestaram dizendo que não conseguiram fazer as visitas.

Em decorrência de dúvidas que foram aparecendo, houve o esclarecimento que a acupuntura na UBS Vila Progresso é direcionada para os USUÁRIOS da unidade, as vagas não são abertas no SIGA. Os clínicos dessa unidade têm essa formação e praticam nos USUÁRIOS. Para o TERRITÓRIO, as vagas disponíveis são do Hospital Cachoeirinha. Uma participante disse que na maioria das UBS há grupos de auriculoterapia.

Discutiu novamente a necessidade das PESSOAS COM DEFICIÊNCIA não ficarem restritas aos espaços de saúde, ressaltando a importância de agenciarmos a presença delas em outros lugares e ocupar esses espaços. Nesse sentido, falou que fazer REABILITAÇÃO foi-se tornando outra coisa, anteriormente era voltado para o organismo e passa a ser esse organismo em atividade no ENCONTRO com as BARREIRAS e os RECURSOS. Então, mudamos o foco para esse ENCONTRO, possibilitando perceber os "NÓS" e pensar em estratégias que foquem os mesmos. "Tem um trabalho que é específico, mas tem uma outra camada que vai puxando para FORA". Como é a AUTONOMIA dos SUJEITOS fora dos espaços de saúde e REABILITAÇÃO?

Ela problematizou que a PESSOA COM DEFICIÊNCIA não é PROTAGONISTA na vida, os outros vão dizendo a todo tempo o que fazer. Ressaltou ser importante olhar para isso desde a atenção básica até a especializada e pensar o PROJETO TERAPÊUTICO com foco no PROTAGONISMO do SUJEITO, considerando que isso é um trabalho nosso. Discutimos sobre trabalhar dentro do PROJETO DE VIDA dos usuários, para que consigam ocupar os espaços. Pontua que vamos nos dando conta, junto com os usuários de uma DEMANDA que antes era só deles. "A gente vai se empoderando de um projeto terapêutico que vai pra vida mesmo". Ela problematizou: Quando na saúde vamos pensar em ACESSIBILIDADE de transporte? Quando vamos pensar em como o USUÁRIO vai ACESSAR o serviço de saúde, como ele vai chegar nos lugares, enfatizou que se queremos garantir o ACESSO, precisamos "sair um pouquinho".

O CER fez a visita no Centro Esportivo da Freguesia do Ó (CEFÓ). Ela descreveu o lugar como sendo grande, mas com diversas escadas para ACESSAR as quadras. O único espaço ACESSÍVEL é o prédio, onde no térreo fica o administrativo e somente nos outros 
dois andares há espaço para as atividades, mas não há elevador e nem rampas, só escadas. Ela foi problematizando a localização do administrativo na única parte ACESSÍVEL do prédio, que talvez pudesse estar em outro lugar para viabilizar que pessoas com dificuldade de mobilidade pudessem ACESSAR. Discutiu que talvez fazer atividades lá produziria diálogo nesse sentido ou talvez produziria desconfortos que pudessem impulsionar mudanças. No entanto, ela pondera que isso que estava fazendo era um exercício de pensamento e um processo de construção em conjunto, que talvez não seja por esse caminho. Pontuou que há necessidade de fazer coisas em diferentes níveis, tanto na GESTÃO como em outras camadas para gerar movimentos.

Conversamos sobre as leis de ACESSIBILIDADE serem frequentemente desrespeitadas. Ela discutiu que por outro lado os critérios são bastante rígidos. Destacou que na lei está presente um critério de razoabilidade, porque uma trilha no meio do mato mesmo com corrimão não faz gerar ACESSO, como é o caso do Centro Esportivo. Fomos dizendo sobre a falta de ACESSIBILIDADE de nossas casas, que nos impossibilitaria receber a visita de uma pessoa com cadeira de rodas.

Fiz um questionamento sobre onde há verba disponível, porque apesar de concordar que precisamos fazer disputas em diversos âmbitos, ressalto que inclusive deveríamos pressionar setores com dinheiro para poder operacionalizar mudanças, como a sub-prefeitura da região. Então, usar a lei a nosso favor.

Fizemos uma discussão sobre ocuparmos diversos lugares junto com os USUÁRIOS para que isso cause DESLOCAMENTOS. Em diálogo, comentei que assisti o vídeo da Secretaria de Direitos Humanos, que havia sido anteriormente indicado. O vídeo conta a história de como as PESSOAS COM DEFICIÊNCIA fizeram esse movimento político de ocupar os lugares, conta também sobre a dificuldade de construir o I Ano Internacional da Pessoa com Deficiência. Essas ações foram produzindo diversos DESLOCAMENTOS e também possibilidades de maior PROTAGONISMO desses SUJEITOS. Destaquei, então, que observo diversos lugares por onde circulo INACESSÍVEIS para cadeira de rodas, mas o quanto é diferente nós, profissionais de saúde, problematizarmos isso ou estar presente uma pessoa que não consegue se deslocar por causa de uma barreira arquitetônica, e que este causa muito mais impacto.

Falou sobre uma dada verba da Secretaria da Assistência Social para reformar as casas e torná-las mais ACESSÍVEIS, mas é para fins pontuais e específicos, como corrimões no 
banheiro. Ela falou que não tinha a informação se essa verba ainda existe em decorrência dos cortes que foram feitos. Nessa fala, ela também puxou um gancho para falar da INTERSETORIALIDADE e da nossa relação com a assistência social, onde pontuou que alguns tensionamentos são frequentes nessas articulações.

Falamos sobre linhas de créditos especiais para tecnologia assistiva e como a iniciativa privada vai se usando disso. Ela falou que acredita que as PESSOAS COM DEFICIÊNCIA também passaram a ser vistas como consumidores e que consomem carros adaptados com isenção de impostos. Isso desencadeou um movimento de reformas em consultórios dos médicos que fazem avaliação para aquisição ou renovação da $\mathrm{CNH}^{7}$, em decorrência da DEMANDA de PESSOAS COM DEFICIÊNCIA nesses consultórios. Em diálogo, ela falou também do aumento de $25 \%$ da aposentadoria para pessoas que precisam de CUIDADORES como isso vem acontecendo, mas pontuou que muitas pessoas ainda não têm ACESSO à essa informação. Desse modo, levantamos a necessidade de juntarmos essas informações, para serem ACESSÍVEIS a todos e contribuirem para viabilizar o ACESSO dos USUÁRIOS, para que não fiquem sem os seus direitos por falta de conhecimento.

Falei da visita que fiz ao Núcleo de Convivência de Idosos chamado Núcleo Coração Materno, sugestão da fisioterapeuta que trabalha comigo, por indicação de um 'paciente' dela. Falei da minha dificuldade em chegar ao local, pois é afastado e em região de favela e no percurso com o GPS passei por uma situação que me deixou apreensiva.

O Núcleo é uma Organização Não Governamental (ONG) que apresenta ligação com um Centro Espírita e recebe verba da Prefeitura de São Paulo via Secretaria de Assistência Social. Eles ofertam diversos grupos de atividades, dentre eles Yoga, Dança Circular, Tai Chi. O horário de funcionamento é das 8:00 às 11:00 e das 14:00 às 17:00 horas, servem café da manhã e café da tarde, mas não servem almoço. É direcionado para idosos acima de 60 anos, que vão para atividades específicas, não é um Centro de Convivência de idosos onde ficam o dia todo, mas podem fazer todas as atividades que desejarem, é aberto. Os grupos são grandes, com participação entre 60 e 70 pessoas nos maiores e entre 30 e 40 nos menores.

Uma das atividades chama "Colo de Vó", em que alguns idosos do grupo vão na casa de outros idosos, que anteriormente frequentavam o núcleo, mas atualmente não conseguem mais se deslocar até a unidade. Questionei sobre o ACESSO de pessoas com os diferentes

\footnotetext{
${ }^{7}$ Carteira Nacional de Habilitação.
} 
tipos de DEFICIÊNCIA, disseram que a maior dificuldade é para chegar, porque é uma região de morro, há muitas subidas e descidas, mas o prédio é ACESSÍVEL para cadeira de rodas.

Fizeram diversas perguntas sobre fisioterapia e o fornecimento de OPM (Órteses, Próteses e Meios Auxiliares de Locomoção), esclareci algumas delas, mas pontuei a necessidade de se aproximarem das UBS da região, porque eu faço parte do NIR. Disponibilizei meu e-mail para eventuais dúvidas, mas enfatizei que o contato para solicitação de fisio e de OPM é com a UBS não seria direto comigo, pois são eles que fazem o acompanhamento e o encaminhamento dos USUÁRIOS. No Fórum ressaltei que percebi a necessidade e a importância das UBSs da região se aproximarem deles e fazerem conversas, até mesmo porque o trabalho que fazem lá eu achei bem interessante e há abertura para essa aproximação. Algumas participantes relataram que já foram feitas conversas, mas precisariam provavelmente retomar porque as pessoas dos serviços mudam. Ressaltou a importância de reafirmar esse contato com a UBS, porque do contrário produzimos uma via direta com a especializada, considerou ser importante que esses casos passessem pela Atenção Básica e fossem acompanhados por eles.

No núcleo, ao ser questionada sobre a fila de espera de fisioterapia falei do modo como produzimos outras OFERTAS DE CUIDADO para além da REABILITAÇÃO, e que a partir disso percebemos esses espaços como sendo potentes, porque não é toda dor que precisa de um fisioterapeuta. Eu falei para eles que encaminho diversos USUÁRIOS para o Yoga, Lian Gong e os mesmo referem melhora do quadro álgico. Essas são atividades também disponíveis no núcleo e reforço a importância delas para os idosos, principalmente considerando que fica próximo à moradia deles, pelo fato do lugar é distante isso dificulta 0 ACESSO das pessoas daquela região aos serviços de reabilitação. Eles receberam com surpresa e empolgação essas colocações que fiz.

Ela discutiu a falta de articulação entre os serviços e citou o CRAS, dizendo que o usuário fica recortado "fica um pedacinho em cada lugar". Quem tem $\mathrm{BPC}^{8}$ tem prioridade no $\mathrm{CCJ}^{9}$, pontuou que não gosta da palavra prioridade porque carrega a ideia que a pessoa "vai furar fila", disse que acredita que não se trata disso, mas de garantir que as pessoas também sejam INCLUÍDAS.

\footnotetext{
${ }^{8}$ Benefício de Prestação Continuada, que beneficia idosos acima de 65 anos e pessoas com deficiência que comprovadamente não tenham meios para sua subsistência, nem mesmo as famílias.

${ }^{9}$ Centro Cultural da Juventude, localizado no bairro da Cachoeirinha.
} 


\subsection{1 - Visita do CRI (Centro de Referência do Idoso) nas unidades}

Trabalhadores do CRI foram aos serviços de saúde de ambas as supervisões. Em algumas unidades falaram sobre VAGAS que ficavam ociosas, o que gerou diversas dúvidas e discussões sobre as vagas.

Pontuou que foi uma aproximação, e que eles queriam conhecer os SERVIÇOS, mas no seu serviço aproveitaram para saber mais sobre CRI também.

Ela contou que por causa dessas visitas foi ao CRI para obter mais informações. Contou também que há um espaço de convivência lá que é aberto e não é necessário encaminhamento, mas precisa de atestado médico para o ACESSO a algumas atividades. Outro ACESSO é pelo CROSS através de vagas de especialistas e triagem em reabilitação (não há vaga específica de fisioterapia), não há fila de espera e isso causou estranhamento a todas. Pontuou que o CRI está no processo de rever o CID para ACESSO à REABILITAÇÃO, porque alguns CID não são compatíveis com as possibilidades de ofertas. Ela descreveu que na equipe do CRI há atualmente um educador físico que orienta atividades no processo de alta, principalmente, mas não só "naquelas academias de praças". Nos informou que há uma dessas no Complexo Hospitalar do Mandaqui ${ }^{10}$. Quando ela fez a visita os USUÁRIOS estavam fazendo um número menor de sessões de REABILITAÇÃO, mas recebem essas orientações do educador físico.

Diversas participantes ressaltaram que é interessante esse movimento do CRI de disponibilizar um educador físico para fazer orientações de atividades, que isso possibilita mais qualidade dessas orientações e do processo de alta.

Foi esclarecido que realmente não há fila de espera no CROSS para o ACESSO à triagem de reabilitação no CRI. Pontuou que é possível visualizar no sistema as vagas e, caso estejam disponíveis, o agendamento é feito no mesmo momento. No entanto, é necessário fazer entradas periódicas para pesquisá-las no sistema, pois abrem poucas vagas por mês.

\subsection{2 - Propostas}

${ }^{10} \mathrm{O}$ CRI localiza-se no Complexo Hospitalar do Mandaqui. 
1. Os participantes deveriam compartilhar por e-mail os materiais que trouxeram dos locais e das atividades;

2. Propus fazermos em novembro uma análise do percurso do Fórum em 2018, começando de quando fizemos a conversa de repensar o espaço do Fórum. Acharam que não era o momento de parar para fazer essa análise, pois não teria o que analisar ainda, considerando que estávamos construindo o espaço e fazendo esse percurso;

3. As articuladoras de reabilitação deveriam tentar fazer aproximação com "o esporte" e se informarem a respeito de alguma forma local de gestão;

No mês de outubro não haveria Fórum, porque coincidiria com a data do feriado.

\section{4 - FÓRUM DE NOVEMBRO}

São apresentadas as pautas, dentre elas a proposta de organização de uma Semana da PESSOA COM DEFICIÊNCIA, que seria na primeira semana de dezembro, já que o dia internacional da pessoa com deficiência é 03 de dezembro.

Iniciamos a conversa sobre um evento científico organizado por um grupo da USP sobre PICS $*^{11}$, onde seria discutido o respaldo científico das práticas no sentido de crítica às mesmas e aconteceria em um hotel. Algumas pessoas decidiram ir para ter mais informações. Isso suscitou a discussão sobre as PICS serem uma APOSTA nossa. Não só acreditamos e OFERTAMOS para os USUÁRIOS, mas também as praticamos e as usamos. A qualidade com que fazemos essas ofertas alternativas de cuidado e o modo como as produzimos é discutido, assim como outras possibilidades de OFERTAS que vamos construindo. Pontuamos ser necessário investimento para que essas ações não apresentem 'qualidade ruim' e para que sejam cuidadoras.

Falaram sobre as visitas realizadas pelo CREFITO-3 ${ }^{12}$ na região da STS da Casa Verde, Cachoeirinha e Limão e sobre o modo como os fiscais têm feito as abordagens e que não estão ocorrendo na Freguesia do Ó e Brasilândia ainda. No entanto, diversas

\footnotetext{
${ }^{11}$ Práticas Integrativas e Complementares em Saúde.

${ }^{12}$ Conselho Regional de Fisioterapia da Região 3, que corresponde ao estado de São Paulo.
} 
fisioterapeutas estão apreensivas, pois o número de usuários nos grupos é maior do que o Conselho permite. No território da Casa Verde/Cachoeirinha/Limão houve a notificação de uma profissional. Problematizamos a necessidade de suporte da gestão para continuarmos produzindo os grupos terapêuticos do modo como vinhamos fazendo, e questionamos quais movimentos que vinham sendo operados pela GESTÃO a respeito. Disseram que a STS da Freguesia do Ó e Brasilândia tinha a intenção de fazer conversas com fiscais do CREFITO-3 e, assim, obter mais informações sobre essas visitas e tentar fazer articulações com o Conselho.

Pontuamos que isso estava acontecendo de diferentes modos e diferentes posturas dos fiscais, que provavelmente também viriam para a Freguesia do Ó/Brasilândia. Direcionamos a conversa para pensar em algumas possibilidades. Uma proposta foi colocar outro profissional junto com as fisioterapeutas nos grupos grandes, pois assumiria outra configuração. Há também a exigência do Conselho que os atendimentos em grupos fossem evoluídos em prontuários, o que não vinha sendo feito. Algumas fisioterapeutas dos NASFs já começaram a organizar as agendas para fazerem isso mensalmente.

Retornamos à conversa sobre a Semana da Pessoa com Deficiência que o CER estava organizando e convidou os serviços para comporem. Trouxeram um calendário ainda inacabado com algumas propostas de atividades, mas ficaram de enviar na semana seguinte mais organizado. A proposta era circular nos diversos lugares para além da saúde e fazermos diferentes tipos de atividades como ocupar alguns espaços, dentre os quais o Fórum da Infância. Faríamos isso propondo atividades com o tema da deficiência. No CER, os atendimentos semanais dos usuários seriam desmarcados, para que participassem junto com os profissionais das atividades programadas.

Nesse sentido, a I Semana da Pessoa com Deficiência viria para dar continuidade à construção que estávamos fazendo ao longo do ano, construção essa de estreitar relações e produzir espaços acessíveis, assim como produzir conversa com esses lugares e fazer a intermediação das PESSOAS COM DEFICIÊNCIA nesses espaços, além de dar VISIBILIDADE para questões sobre a REDE DE CUIDADO À PESSOA COM DEFICIÊNCIA, em diálogo com diversos serviços de saúde do TERRITÓRIO. Todos e todas foram convidados a estar JUNTO. Fizeram a seguinte proposta de atividades e lugares: Diretoria Regional de Ensino que fica próxima à Supervisão de Saúde; Fórum da Infância; 
aula da PUC relacionada ao tema; ensaio do "meu bloco na rua""13 que é feito na Casa de Cultura da Brasilândia; Capoterapia no Centro Cultural da Juventude da Cachoeirinha; atividades no CEU Paulistano; oficina de lambe-lambe com as pessoas que ocupam o CER e colar essas fotos do lado de fora do serviço; discussão sobre legislação, ACESSIBILIDADE e DEFICIÊNCIA; dentre outras atividades.

${ }^{13}$ É um bloco de carnaval que envolve os usuários, principalmente do CAPS Adulto e da APD e ensaiam às quintas-feiras na Casa de Cultura da Brasilândia. 


\title{
4- CAPÍTULO 3: O FÓRUM E A REDE
}

\begin{abstract}
Criar situações individuais e coletivas de auto interrogar o próprio sentido do fazer no mundo do trabalho - colocando como sua base a pergunta sobre o que faz com o trabalho vivo em ato, para onde ele é apontado em termos ético-políticos (produz mais vida ou não) - traz também novas perguntas, como, por exemplo, o que se faz com o que já se sabe fazer e com o que se acha que se deve fazer sobre ou junto com os outros, com quem se encontra no mundo do trabalho.[...] Isso implica colocar entre parênteses, parafraseando Basaglia, o sabido a priori que há nesses campos de práticas, para deixar vazar em cada um e nos outros a nova constitutividade que se tem ao se construir com o outro novas possibilidades para os modos de andar a vida, tomando como base os processos de viver que, de modos perspicazes, são construídos de maneira efetiva por cada um e por qualquer um. Isso permite ser afetado por essas perspicácias e se auto interrogar, inclusive como coletivo que se é. A chance de que se venha a conectar novos processos de produção autopoiéticos de vida é alta, mas nunca uma garantia e uma obrigação. $\mathrm{O}$ operar em alteridade com $\mathrm{o}$ outro na produção do viver implica sempre um disputar, sempre uma tensão. [...] Agir com o outro na interseção dos encontros que ali operam, produzindo modos de viver, talvez seja o sentido mais interessante desses trabalhos. Colocar os saberes tecnológicos a serviço disso no interior dos atos produtivos talvez seja a grande apreensão possível para quem procurar desaprender os modos predominantes desses campos de práticas, se realizarem, hoje, quando a vida virou um objeto de manejo e não uma conexão autopoiética no mundo, como produção coletiva (MERHY, 2009, p.36)
\end{abstract}

Durante a descrição do campo de pesquisas aparecem preocupações que compartilho com Grisolia (2017), dentre elas como fazer aparecer o campo sem que isso pudesse causar desconforto nas pessoas que compõem esse espaço. Assumo um compromisso ético com o território e com as participantes de não desqualificar o esforço diário que empreendemos na construção do SUS, considerando as inúmeras dificuldades que isso implica e as diferentes maneiras de fazer. Nos reunimos em espaços coletivos também na tentativa de processarmos nossas angústias e dificuldades e aí incluem-se mesmo os gestores ${ }^{14}$ que constroem o espaço.

Grisolia (2017) apresenta como campo de pesquisas o Fórum da Rede de Atenção Psicossocial (RAPS) da STS Casa Verde, Cachoeirinha e Limão. Ela manifesta alguns tensionamentos de estar pesquisadora no local de trabalho e cito o trecho a seguir: "Em outros momentos senti medo do que iria dizer sobre o modo de funcionamento do SUS no território"

\footnotetext{
${ }^{14}$ Considero como gestores a quem cabe formalmente governar. No entendimento que possuem papel decisivo na conformação das práticas em saúde, mas não governam sozinhos. Todos governam, gestores, trabalhadores e usuários, mas com "recursos de poder e governabilidade distintos" (FEUERWERKER, 2014, p.68), assim como todos fabricam políticas em seu cotidiano de trabalho. Assumindo isso, uma postura democrática dos gestores que possibilite ampliação do debate na produção das políticas, pode ser proveitosa e produtiva. (FEUERWERKER, 2014)
} 
(GRISOLIA, 2017, p.64). Além de identificar-me com o lugar da autora e também ter apresentando inseguranças nesse sentido, acredito que isso diz sobre certa produção do que seriam "modelos idealizados" de fazer as práticas, assim como de pesquisas acadêmicas que fazem denúncias ou críticas. Desse modo, pesquisas produzidas por trabalhadoras do SUS, para falar das práticas e do cotidiano dos serviços, apresentam de inaugural outro plano de olhar para o Sistema de Saúde, com abertura para dimensões micropolíticas que operam nas fissuras do sistema. Aparece o SUS com vetores micropolíticos que tensionam a prática, extrapolando aquilo que é teorizado, objetivado e idealizado. Desse modo, vai ficando evidente como as políticas de redução de custos atravessam os serviços, como a horizontalização da gestão opera na gestão do cuidado, como as políticas de terceirização fragilizam o vínculo dos trabalhadores, como a política de saúde médico-hegemônica atravessa as práticas de saúde, como a troca de gestão municipal impacta nos atendimentos, na organização das agendas e na possibilidade de ofertas de cuidado, entre outras.

A pesquisadora dialoga com autores que discutem as possíveis origens da palavra Fórum, e conclui com o entendimento de que:

Portanto, a origem da palavra Fórum nos sugere um lugar de fronteira entre o dentro e o fora, entre o público e o privado, entre o familiar e o desconhecido. $\mathrm{O}$ autor nos diz que o conhecimento pode ser alcançado através da topografia, que nos serve para descrever as relações de vizinhança e proximidade, sem qualquer necessidade nem da distância nem da quantidade para mediá-la. (GRISOLIA, 2017, p.22)

Grisolia (2017) dialoga com Francisco Wintaker $(2005)^{15,}$ envolvido com a produção do Fórum Social Mundial, que compreende o Fórum como um espaço aberto, de gestão horizontal, sem hierarquia e sem dirigentes. Trata-se de uma nova cultura política, sendo autônomo em relação a partidos e governos e possibilita o aprendizado de uma ação política que respeita a diversidade. A autora afirma que os espaços organizados em uma perspectiva coletiva de participação carregam a potência de produzir encontros e também de aquecer as redes de saúde e possibilitar soluções criativas para a construção de um SUS de qualidade. Esses encontros possibilitam aos trabalhadores em saúde produzirem realidades e resistirem à macropolítica dos gerenciamentos. Nesse sentido, propõe o Fórum como um arranjo 
organizacional que visa à produção de encontro entre trabalhadores de diversos serviços, possibilitando a co-gestão do trabalho, mas que apresenta como finalidade, dentre outras, a contrução da Rede de Atenção à Saúde (RAS). Considera os fóruns em saúde como locais privilegiados de construção de redes vivas que não se restringem a um arranjo organizacional da gestão, mas sim como produção autônoma dos trabalhadores. Entende os Fóruns de saúde como dispositivos de construção de redes, onde há possibilidade de democratização da gestão em saúde.

Grisolia (2017) reforça o entendimento do Fórum como um espaço aberto e democrático, que constrói fronteiras entre serviços, profissionais e usuários. Constitui-se também como um espaço político de luta e resistência, movido pela utopia ativa do SUS e apresenta a potência de invenção da saúde como bem público. Configura-se, então, como um espaço de debate e aprendizagem em rede, onde se planejam estratégias coletivas que podem culminar com ações transformadoras.

$\mathrm{Na}$ tentativa de falar sobre o Fórum, o conceito de Rede também se fez presente. Nesse percurso, tanto conceitual quanto de vivência do campo, fui percebendo o Fórum de Reabilitação da Freguesia do Ó e Brasilândia como um espaço coletivo de gestão horizontalizada, que possibilita o encontro de diferentes atores no esforço de produzir Redes das mais diversas. Desse modo, eu o qualifico, entre tantas dizibilidades que poderiam ser produzidas, como um dispositivo de rede.

A palavra Rede é utilizada e conceituada por diferentes áreas, como a filosofia, as ciências humanas e exatas, a arte e a tecnologia (GRISOLIA, 2017). É frequentemente associada a outros termos que a qualificam, como: redes temáticas, rede de atenção à saúde, rede de cuidado, rede viva, rede quente, rede tecnoassistencial em saúde, redes de trabalho em saúde, redes transversais, redes existenciais, redes de trabalho afetivo, redes organizacionais, entre outras. No entanto, os termos não são equivalentes entre si.

O texto "A Produção de Redes de Encontro e a Produção de Saúde no SUS" (AZEVEDO e col, 2013) contribui com o estado da arte da conceituação das Redes. Traça um percurso sobre Rede que é também historicamente mostrado e conceituado em diferentes perspectivas. Coloca em discussão qual ideia de rede os interessa, elaborando dois questionamentos importantes. Em nome de um arranjo de rede, o trabalho deixa de produzir 
redes nos encontros? Como transformar redes duras em redes que sejam maleáveis à singularidade de cada território? Aparecem inúmeras concepções de rede desenvolvidas por diversos autores, algumas que produzem vizinhança entre si e outras que divergem. Destaca que nos diversos países são utilizados diferentes termos para fazer referência à implementação e desenvolvimento de rede, que apresentam pequenas variações entre si. Entretanto, múltiplos termos são empregados, constituindo um espectro de 175 definições e conceitos (KUSCHNIR e CHORNY, 2010 apud AZEVEDO e col, 2013). Nesse contexto, é um grande desafio aproximar-me das diversas conceituações de Rede, o que divergiria dos meus objetivos. Interessa-me entender qual rede é essa que aparece no Fórum de Reabilitação da Freguesia do Ó e Brasilândia, compartilhado com a STS da Casa Verde, Cachoeirinha e Limão no ano de 2018. Então, ressalto algumas definições com o objetivo de qualificar o modo como fomos produzindo Rede a partir do recorte de pesquisa efetuado.

Em 2010 o Ministério da Saúde estabeleceu diretrizes para a organização do SUS em Redes de Atenção à Saúde (BRASIL, 2010). Em 2012 é publicada a Portaria que institui a Rede de Cuidado à Pessoa com Deficiência no SUS (BRASIL, 2012). Essas publicações foram estruturantes, dentre outras, para a reorganização do SUS em Redes, apesar de anterior a isso o termo Rede já estar presente na Constituição de 1988, assim como em publicações de autores conceituados na Saúde Coletiva como Teixeira (2004). As publicações e produções de pesquisa sobre o tema foram então aquecidas a partir de 2010.

No entanto, as formulações do Ministério da Saúde indicam uma rede inteira, sólida, com uma modelagem analógica sugerida, onde toda a previsibilidade poderia ser definida, com extenso controle de governabilidade. Em contraposição, as Redes Vivas são fragmentárias e em acontecimento, montam e desmontam e eventualmente tornam-se estáveis. Uma rede analógica pode ser disparadora, mas será atravessada por inúmeras outras não analógicas. Os usuários são Redes Vivas de si, que vão produzindo diversos movimentos, por isso, muitas vezes quem pede as redes são eles próprios. (MERHY, 2014)

Penso que, apesar da nomenclatura sugerir uma rede temática (Rede de Cuidado à Pessoa com Deficiência), assim como o nome do dispositivo (Fórum de Reabilitação) faz alusão a certo modo de produzir a prática, o que se destacam são outras apostas. O Fórum como ocorre, frequentemente abre possibilidades de outras redes se constituirem, extrapola os 
limites de uma rede temática analógica, assim como de uma prática de reabilitação engessada e conceitualmente determinada a priori. É um dispositivo de rede que possibilita produzir outras redes, no entendimento de que promover espaços de encontro é um facilitador de construção de microrredes. Vamos reafirmando então, a abertura para conversa entre os diferentes serviços de saúde, assim como vamos tentando estabelecer conexões com o que está fora dos espaços de saúde.

Pensar a organização através de Redes é uma das propostas de gestão, visando a superar a fragmentação dos serviços, dos programas, das ações e das práticas clínicas, com vistas também à racionalização dos custos em saúde. No entanto, organizações excessivamente normatizadas restringem o trabalho em rede e ignoram suas contribuições, que são micropolíticas. (AZEVEDO e col, 2013)

O desafio da conexão entre as redes é um problema elaborado por Righi (2010), que propõe a criação de arranjos e dispositivos que permitam o encontro entre sujeitos com diferentes saberes, possibilitando a construção de novas questões e proposição de intervenções diferentes, assim como estabelecer acordos entre os nós dessa Rede, formando efetivas redes de produção de vida. (AZEVEDO e col, 2013)

Olhar para os processos que perfazem a construção de redes, como os seus nós, as linhas de força que atravessam e os seus agenciamentos, pode apoiar iniciativas nesse sentido. Os autores optam por olhar para as redes como processos construídos pelos atores que nelas habitam, que não são pré-determinadas por complexidade ou temas de assistência à saúde. É uma aposta permeada pela discussão da relação com as formas e lugares, também um olhar sobre como as singularidades são apreendidas no coletivo. Reforçam a importância do trabalho e do componente relacional para a construção de redes, sendo a rede um espaço de construção de sujeitos, subjetividades e produtor de saúde. A produção de espaços coletivos com zonas de trocas e ampliação dos processos colaborativos é necessária para que outros arranjos de rede sejam possíveis. As ampliações dessas zonas de trocas, da comunicação e das construções conjuntas conferem resistência aos espaços coletivos. (AZEVEDO e col, 2013)

A radical aposta na construção coletiva, na democracia institucional e na corresponsabilização são meios sugeridos para o fortalecimento das redes, no sentido de produzirem saúde e vida. Não é a qualquer rede que os autores fazem alusão, mas à uma rede 
onde seja possível reconhecer potência na diferença, possibilitando produções coletivas nessa perspectiva. (AZEVEDO e col, 2013)

Descrevem uma rede-rizoma, onde o encontro entre mundos diferentes dá sustentação à constituição dessas redes, quaisquer pontos podem se conectar. A rede opera de modo a possibilitar linhas de fuga e o seu rompimento para se refazer, remetendo-se a elas mesmas. “Constituem territórios e graus de desterritorialização. Um rizoma o é, mesmo sem um aparato que o centralize e organize”. (AZEVEDO e col, 2013, p.16)

Em 2004, Teixeira já falava sobre as redes de trabalho em saúde, concebendo-as como grandes redes de conversações. Considerando que todos sabem alguma coisa, mas que ninguém sabe tudo, a arte da conversa não é homogeneizar os sentidos e fazer desaparecer as divergências, "mas fazer emergir o sentido no ponto de convergência das diversidades" (TEIXEIRA, 2004, p.4). Sobre as redes de trabalho afetivo, ele afirma que são redes de produção de afetos, sendo a própria produção de redes sociais, de comunidades, de formas de vida, de produções de subjetividades e de sociabilidade, "Redes de produção de redes" (TEIXEIRA, 2004, p.5).

O Fórum de Reabilitação é um recorte, e como tal, produz certas visibilidades e dizibilidades. Um dos limites levantados pelo Fórum é relacionado à participação, visto que a maioria das participantes são "profissionais da reabilitação", apesar de nos encontros citados ter havido a presença de trabalhadores de outras áreas e estagiários. O campo foi-me conduzindo a certas buscas e a percorrer diversos caminhos que não existiam a priori, como estudar o conceito de deficiência e reabilitação, assim como a contextualização do território por meio das pesquisas que já haviam sido publicadas. Também apareceu a possibilidade de aproximação com a autora Maria Cecília Ferro Donnangelo (DONNANGELO e PEREIRA, 2011) como interlocutora.

Alguns termos e conceitos foram por mim destacados. Dentre eles: participação social, inserção/exclusão, barreiras/facilitadores, limite terapêtico, escuta, protagonismo, pessoa com deficiência, deficiência, normal (normalidade), desejo, escolha, reabilitação, prática, movimento 'De' e 'Para' pessoas com deficiência, vida independente, autonomia, incapacidade, voz, luta, escola/sala especial/regular, barreiras (atitudinais, arquitetônicas, sociais, culturais), fala de lugar, diferença, experiência, vivência, surdez/deficiência auditiva, cegueira/deficiência visual, entre, encontro, ressignificação, demanda, corpo, práticas 
corporais, preconceito, poder, prognóstico, potência do encontro, vínculo, comunidade, relação, intervenção, cuidado de si, padrão, habilitada/desabilitada, coresponsabilização, cenas, casos, atores, captura, necessidade, oferta, cuidado, adaptação, outro, escuta qualificada, contra-transferência, processamento, diagnóstico/CID, recursos, nós, dentro/fora, projeto de vida, acessibilidade, acessibilidade ao transporte, projeto terapêutico, gestão, deslocamento, acessível/inacessível, cuidadores, aposta.

A escolha de certos conceitos e não outros diz sobre posicionamentos e escolhas, assim como de direcionamentos políticos, considerando ainda que são carregados de significados. Entretanto, são eventualmente utilizados de maneiras adversas pelas personagens do Fórum. Eu os destaco porque acredito que evidenciam os desafios que são postos no plano das práticas, onde inúmeros conceitos apresentam diferentes significações no entendimento de pessoas que partem de lugares diversos, o que ressalta a diferença como produtora de potência. As múltiplas "falas de lugar" possibilitam a produção de um cenário complexificado, onde há abertura para produção de mundos que se conversam. Um emaranhado de linhas vai produzindo o Fórum como um dispositivo de Rede.

O Fórum de Reabilitação é um espaço aberto de falas, acontece em roda e frequentemente é reforçado o convite para que as pessoas presentes tenham liberdade para se expressarem. Evidenciam-se diferentes apostas e modos de pensar a deficiência, a reabilitação, as práticas, o cuidado, mas percebo abertura para o diálogo. A importância de acolhimento dos usuários é reforçada pelas participantes, assim como de dar voz aos mesmos e de fazermos uma escuta que não os descredibilize, ressaltando a importância da produção de cuidado que possibilite produzir vida. A escuta aparece como ferramenta para diminuir a angústia das equipes de saúde no cuidado com os usuários, mas também para escaparmos da captura que o modelo hegemônico de pensar a saúde produz, ao normatizar os corpos e a vida. Assim como será discutido adiante, certos modos de "reabilitar" incidem fortemente na normatização dos corpos e das vidas das pessoas com deficiência, produzindo rupturas com teias de sentidos e sofrimento. Uma das fisioterapeutas contribuiu com essa discussão trazendo algumas vivências dela no cuidado com os usuários, onde ela problematizou que fazemos suposições e tentamos moldá-los ao nosso modo. Presente na fala dela no Fórum em relação ao usuário o qual ela pensava que tinha uma "expectativa comum" e na realidade ele queria jogar futebol e cair menos, ela também falou de como eventualmente vamos tentando moldar como os usuários estão nas práticas corporais. Nesse momento do Fórum foi 
ressaltada a necessidade de ativamente revermos as nossas práticas e ações em todo momento. Nesse sentido, o CER vem se utilizando do processamento coletivo em suas reuniões, com intenção de colocarem suas sobre-implicações em discussão, para ativamente irem escapando das diversas capturas.

Na discussão sobre as capturas produzidas em trabalhadores e usuários, consideramos que há diversos planos, linhas e forças que atravessam e produzem interferências no modo de pensar a produção de cuidado e de vida. Para fugir dessa captura produzida pelos equipamentos da saúde foi proposto articularmos o agenciamento da presença dos usuários em espaços fora da saúde, espaços menos normatizados e medicalizados, que possibilitem outras vivências e outros modos de tocar a vida. Três cenas citadas ilustram esses deslocamentos vividos: 1) o caso do homem, a filha, o côco, a cadeira de rodas e a escolha; 2) o caso da fisioterapeuta, a sapatilha e o equilíbrio; 3) o caso da fisioterapeuta, o professor de judô, a "órtese" e a atividade. Destaco o trecho a seguir, pois considero que dialoga com esse nosso modo de fazer que vamos problematizamos a nossa prática.

É preciso colocar em análise o conjunto de práticas ofertadas por nossas instituições de saúde, educação, assistência social entre outras. Mapear a existência e a invenção de espaços para fora do muro, nos quais os usuários/as também percorrem em suas trajetórias, bem como re-conhecer os ditos informais e os sentidos que são produzidos neles, é uma boa forma de enxergar o quanto esse mundo tem elementos em aberto, não capturados, trabalho vivo em ato dependente e que se expressam como tensões e disputas pelo seu sentido. (MERHY, 2014, p.160)

No caso da criança diagnosticada com ECNE, com quadro cinesiológico-funcional de hemiparesia, o diagnóstico apresenta-se como um "peso" para a menina, produzindo sofrimento e rupturas no seu modo de vida, que transborda na mudança de comportamento e desempenho na escola. A delicadeza e complexidade do cuidado para essa criança produz inseguranças na fisioterapeuta, que busca apoio no CER para pensarem juntas as ofertas, onde encontra abertura para diálogo e acolhimento das suas angústias. Na apresentação desta dissertação está presente uma experiência semelhante minha. No entanto, o presente caso vai delineando outras possibilidades de cuidar sem captura, sem o "peso do diagnóstico" de uma deficiência. Nessa, e em outras cenas, é também evidenciado o acolhimento das famílias de pessoas com deficiência, com compartilhamento do projeto terapêutico até mesmo com as 
crianças, tentanto construir a possibilidade de autonomia, como no caso da criança que não quer fazer uso da órtese e as profissionais do CER vão pensando como fazer esse cuidado junto com a criança e a família, apesar de problematizarem a inseguraça relacionada à possibilidade de negligência à criança.

Discutimos também as barreiras atitudinais, onde algumas cenas são apresentadas para elucidar como elas produzem limites na participação social de pessoas com deficiência. Dentre elas, a postura do garçom que não entende o "cadeirante" como um interlocutor capaz de expressar seus desejos e então pergunta à acompanhante o que ele iria comer. Outro caso é a moça na fila do caixa do supermercado, que manifesta seu incômodo ao presenciar uma "mulher cega" fazendo compra sozinha, ignorando todo o percurso, todas as produções necessárias e todo o contexto, para que aquela "mulher cega" chegasse ao supermercado sem acompanhante para fazer compras. Neste momento ela reduz a mulher à condição de cega e a entende como incapaz.

As saídas promovidas pelo CER e pela APD aparecem como uma aposta em outros modos de fazer a inserção social dos sujeitos. Na descrição dessas experimentações as profissionais ressaltaram o encontro dos usuários com barreiras, como o limite de transportar somente uma cadeira de rodas por ônibus, dificuldade de acesso dos jovens com deficiência intelectual em dadas atividades, entre outras. Vamos tentando dar conta de diversas frentes que compõem o cuidado à pessoa com deficiência, como a construção da intersetorialidade, estreitando relações com a educação, além de tentativas ainda tímidas de aproximação com a cultura e o esporte. A semana da pessoa com deficiência veio com a proposta de efetivar algumas dessas aproximações e também de pautar amplamente a questão da deficiência no território. Como estratégia, pensamos em inserir essas conversas nos diferentes espaços já consolidados, além de ocuparmos esses e outros lugares junto às pessoas com deficiência. A semana da pessoa com deficiência também foi pensada como um convite, para nos aproximarmos de equipamentos de outras secretarias.

A PUC, como parceira, organizou uma aula para compor com as Atividades da Semana e também se faz presente em outros momentos, apesar do recorte dos encontros do Fórum de Reabilitação não evidenciarem essa presença. No Fórum de junho houve uma capacitação para profissionais da Atenção Básica, ministrada por uma das perceptoras junto com estagiárias do curso de fisioterapia da PUC, com os seguintes temas: alterações 
fisiológicas e posturais durante o período gestacional e incontinência urinária em mulheres. Essa proposta de temas surge a partir da demanda de trabalhadores do território. A capacitação acontece em um misto de apresentação de slides, demonstrações e rodas de conversa, que possibilitaram diálogo entre todos os participantes e uma construção coletiva do processo.

O movimento "Nada Sobre Nós Sem Nós" é citado em diversos momentos do Fórum, reforçando que as pessoas com deficiência são porta-vozes de suas necessidades e desejos e não cabe a nós reconhecer ou aceitar, está dado e cabe não limitarmos isso com as nossas práticas. Por outro lado, referimo-nos a pessoas que podem não estar em condições de fazer essas elaborações. Parte dos desafios da reabilitação é potencializá-las para tanto.

Assim como pontuado por Teixeira (2004), as necessidades em saúde são objeto de um debate interminável, em reconhecimento à complexidade com a qual são produzidas, considerando também, como discutido no Fórum, que há diversas linhas de força atuando na sua produção. Gostaria de destacar três dos casos discutidos, onde colocamos em pauta as escolhas e desejos dos usuários. Um deles é o caso do usuário que manifestava o desejo de ficar em pé, pois queria olhar as pessoas no mesmo nível, não de baixo para cima, que é o ângulo pelo qual frequentemente as pessoas sentadas em cadeiras de rodas olham para as outras pessoas. Para isso, dispunha-se a submeter-se a diversas cirurgias. Em outros dois casos: a menina que se locomovia com andador pela insistência da fisioterapeuta; o homem que andava com o auxílio de bengalas canadenses. Fizeram a escolha do uso da cadeira de rodas, na contramão daquilo que é estabelecido, à priori, como modo mais adequado de se deslocar. Nesses casos discutidos, trouxeram diversos elementos para contextualizar seus desejos e suas escolhas, o que ressalta a complexidade da produção das necessidades em saúde, com diversas forças que disputam como: o desejo da fisioterapeuta de que a menina andasse com o andador; a condição de cuidador de uma criança, em que a cadeira de rodas o possibilita levar água de coco à filha, o que não é possível quando as duas mãos estão ocupadas com as bengalas canadenses; a perspectiva sob a qual se conversa com as pessoas e os simbolismos produzidos a partir disso. Destaco o trecho a seguir, pois dialoga com esta discussão e também propõe o acolhimento e o diálogo como ferramentas fundamentais para a possibilidade de cuidado, partindo das necessidades de saúde dos usuários. 
Como já foi dito, trata-se de um acolhimento dialogado e esse diálogo se orienta, fundamentalmente, pela busca de um maior conhecimento das necessidades de que o usuário se faz portador e dos modos de satisfazê-las. Portanto, será preciso primeiramente explicitar qual o tipo de relação se deve aqui estabelecer com a questão das necessidades. E esta corresponde, de fato, a uma das mais finas "operações de passagem" propostas por este dispositivo de conversa, consistindo na pressuposição geral, que deveria pautar todas as conversas e práticas de conhecimento que se dão no serviço, de que nossas necessidades não nos são sempre imediatamente transparentes e nem jamais estão definitivamente definidas, mas são e desde sempre têm sido objeto de um debate interminável, de uma experimentação continuada, em que o que se discute e refaz sem cessar é a nossa própria humanidade. (TEIXEIRA, 2004, p.4)

As redes de atenção, o vínculo, a continuidade do cuidado e a resolubilidade remetem à ideia de integralidade. Quando pensamos a integralidade como eixo da atenção, as necessidades de saúde passam a ser um referencial para organizar os serviços e as práticas em saúde. Considerando que as necessidades de saúde abrangem desde "boas condições de vida, ao direito de ser acolhido, escutado, desenvolver vínculo com uma equipe que se responsabilize pelo cuidado continuamente, assim como ter acesso a todos os serviços e tecnologias necessários" (FEUERWERKER, 2014, p.106).

\footnotetext{
"Tomar as necessidades de saúde do usuário como referência traz muitas implicações, como já discutimos anteriormente. A começar pelo lugar do usuário na produção do cuidado. Apesar de já há algum tempo se reconhecer que o usuário é o gestor de sua própria vida, que ele faz suas escolhas (com a nossa autorização ou não); de se reconhecer também que ampliação de sua autonomia para configurar os modos de conduzir sua própria vida, enfrentando seus (velhos e novos) agravos, deve ser um dos produtos desejáveis do processo de cuidado - desde Canguilhem e Foucault - de modos distintos - passando por Merhy (2006), (2005),(2010), Campos (2006), Ayres (2001), (2002), Teixeira (2003), Caponi (2003), Ceccim (2004), Ferla (2004), Feuerwerker (2008) - a prática predominante nos serviços de saúde é a inversa." (FEUERWERKER, 2014, p.106)
} 


\title{
5 - CAPÍtUlO 4: DEFICIÊNCIA E REABILITAÇÃO DIANTE DO CENÁRIO POLÍTICO DO MUNICÍPIO DE SÃO PAULO: AS DECORRÊNCIAS NAS PRÁTICAS DE SAÚDE E CUIDADO
}

\author{
5.1 - DEFICIÊNCIA E REABILITAÇÃO
}

Devido à diversidade de temas relacionados à deficiência e à reabilitação, assim como ao extenso número de trabalhos publicados, faço alguns recortes. Coloco o foco na deficiência física na perspectiva da fisioterapia.

Diversas disputas estão presentes no processo de conceituação da deficiência, sendo um conceito em transformação. Isso decorre da importância que o entendimento de deficiência apresenta para o processo de reabilitação. No Fórum de Reabilitação da FÓ/Brasilândia problematizou-se o uso de diferentes terminologias para fazer referência à pessoa com deficiência e em dois diferentes momentos isso foi discutido no mês de julho. Em uma das falas foi sinalizado que há uma proposta, feita por alguns movimentos de pessoas com deficiência, de olhar para a deficiência na perspectiva da diferença, que adotam a diferença funcional como terminologia. O artigo do psicólogo e docente Ray Pereira, publicado em 2009, aborda a ideia de homem-padrão como um dado padrão de normalidade, concebido e reforçado pela cultura, que estabelece o modelo de referência para a aparência, a forma e o funcionamento do corpo. Então ele propõe o uso do termo homens e mulheres com diferença funcional, em substituição à pessoa com deficiência, no entendimento de que um dado indivíduo apresenta deficiência quando comparado a certo padrão estabelecido de corpo. Segundo o autor, o termo foi proposto em 2005, na Espanha, pelo Fórum de Vida Independente. Entretanto, a Convenção Internacional sobre os Direitos da Pessoa com Deficiência (CDPD) da Organização das Nações Unidas (ONU) de 2007 (BRASIL, 2012) faz a opção do uso da expressão pessoa com deficiência, que passa a ser utilizada nas publicações governamentais brasileiras, assim como por inúmeros pesquisadores e por movimentos sociais de pessoas com deficiência, sendo um termo mais amplamente utilizado. Desse modo, faço a opção de uso da expressão pessoa com deficiência.

Nesse percurso de retomar os entendimentos sobre deficiência e reabilitação, eu gostaria de evitar certo modo de escrita em que os diversos textos relacionados aos temas se 
repetem. Muitos partem de um histórico da deficiência, passando pelo surgimento dos movimentos "De" e "Para" pessoas com deficiência, nacionais e mundiais, retomam leis, portarias, pactos, convenções, publicações ministeriais, entre outros. Não gostaria de produzir um trabalho de pesquisa que retomasse as mesmas informações, vou deixar isso a cargo do que já foi produzido. Parto disso, pois acredito que poucas coisas são inauguradas quando se gasta energia refazendo o trabalho de outros. Começo estabelecendo que existe uma vasta literatura relacionada aos diversos temas que compõem o cuidado à pessoa com deficiência e, de certo modo, a contextualização está colocada nessas publicações. Esses materiais estão disponíveis nas bases de dados da saúde, em revistas e livros on-line de acesso público. Indico a leitura do livro "Redes de Atenção à Saúde: Rede de Cuidados à Pessoa com Defíciência" da UNA-SUS (Universidade Aberta do Sistema Único de Saúde) (Cardoso, 2017).

O Relatório Mundial da Deficiência (OMS, 2012) foi o texto que escolhi para falar da deficiência, pois é um texto importante de referência mundial, que conta com um número maior que 380 colaboradores de diversos países. Baseado em inúmeras pesquisas na área, dá subsídios para os países signatários da CDPD, dentre eles o Brasil, para a implementação de políticas públicas. É um documento referenciado por grande número de textos publicados sobre a rede e o cuidado da pessoa com deficiência.

O Relatório Mundial da Deficiência faz referência à CDPD e reafirma a deficiência como um conceito em evolução, no qual outros elementos são trazidos para revê-lo em uma perspectiva biológico-psiquico-social. “(...) a deficiência resulta da interação entre pessoas com deficiência e barreiras comportamentais e ambientais que impedem sua participação plena e eficaz na sociedade de forma igualitária”. É em um movimento político que a CDPD é frequentemente reafirmada na perspectiva da deficiência como uma questão relacionada aos Direitos Humanos. (OMS, 2012, p.4)

As barreiras são qualificadas, dentre outras formas, como dificultadoras do acesso, o que as torna produtoras de exclusão do convívio social, assim como da vida política nas comunidades. No entanto, são passíveis de ações governamentais e sociais. No entendimento de que é na relação com as barreiras que faz emergir a deficiência como incapacidade, o problema é deslocado exclusivamente do corpo e acrescido a sua interação com o ambiente. Nesse sentido, a deficiência é conceituada também como um problema social e não mais exclusivamente do indivíduo. Essa relação da deficiência com o social ganha foco no 
Relatório Mundial da Deficiência. Para tanto, diversas pesquisas realizadas nos diferentes países fornecem dados que colocam em evidência essa relação. (OMS, 2012)

Os números produzidos a partir das pesquisas nos dizem que pessoas com deficiência frequentam menos a escola, possuem acesso restrito a oportunidades de emprego e quando estão empregadas apresentam maior probabilidade de demissão. Apresentam piores condições socioeconômicas, o que se intensifica com o aumento da gravidade da deficiência. São frequentes custos extras em decorrência disso e necessários mais recursos para obter os mesmos resultados de pessoas sem deficiência. Indivíduos mais pobres apresentam condições de saúde piores em relação aos mais ricos, assim como maior probabilidade de desenvolverem deficiência em consequência de uma mesma patologia, devido ao acesso inadequado aos serviços de saúde e reabilitação. Riqueza e status social são fatores que contribuem para a superação das limitações e das restrições de participação nas atividades. O relatório evidencia a interferência socio-político-econômica na condição de deficiência, que apresenta menor prevalência nos países com maior renda. Nesse sentido, tanto nos países pobres como nos ricos a renda impacta na distribuição da deficiência, sendo mais prevalente entre as pessoas pobres. A deficiência acomete mais mulheres e idosos. (OMS, 2012)

Partindo do contexto acima exposto, é ressaltada a necessidade das redes de segurança e proteção social considerarem as especificidades da deficiência para pessoas no contexto da pobreza, visto que apresentam maior dificuldade para o acesso a essas redes e também enfrentam barreiras das mais diversas, dentre elas a dificuldade de acesso físico aos lugares, assim como às informações. Reafirma os custos extras que a deficiência demanda, então, sugere que isso seja relevado prevendo maior valor de benefício direcionado a essas pessoas nos programas de proteção social. Sugere também que programas ocupacionais tenham cotas e que as medidas de convocação para o trabalho sejam sensíveis à deficiência. (OMS, 2012)

É destacada a abordagem de habilidade de Amartya $\operatorname{Sen}^{16}$, que compreende que a pobreza das pessoas com deficiência, assim como de outros povos excluídos, apresenta como consequência também a exclusão e a falta de poder e não somente a falta de recursos materiais. Abordagem esta discutida por diversos autores e destacada a seguir. (OMS, 2012)

\footnotetext{
${ }^{16}$ Professor de economia e filosofia na Universidade de Harvard. Recebeu o Prêmio Nobel em Economia no ano de 1998.
} 
Ela enfatiza a diversidade das aspirações e escolhas que as diferentes pessoas com deficiência podem possuir nas diferentes culturas. Ela também soluciona o paradoxo que muitas pessoas com deficiência expressam, de que possuem uma boa qualidade de vida, talvez porque elas tenham sido bem sucedidas em se adaptar a sua situação. Como Sen tem dito, isso não significa que não seja necessário pensar no que pode ser objetivamente avaliado, como suas necessidades não atendidas. (OMS, 2012, p.12)

A reabilitação é apresentada como um conjunto de medidas direcionadas às pessoas com deficiência, ou prestes à adquiri-la, que visam à aquisição ou manutenção de uma funcionalidade que atenda às necessidades de interação com o ambiente em que a pessoa está inserida. Seus objetivos tinham como foco o grau de deficiência, mas foram ampliados para incluir progressos na atividade e na participação social da pessoa. Nesse sentido, as práticas não podem incidir somente no corpo, é necessária a revisão da sociedade para produzir um comum, onde essas pessoas possam ser efetivamente incluídas. A viabilidade de inserção desses sujeitos na sociedade perpassa diversos setores, incluindo as comunidades, o que torna indispensável a construção de amplo diálogo entre as diferentes partes. (OMS, 2012)

As necessidades não satisfeitas de reabilitação podem piorar a qualidade de vida e condição de saúde das pessoas com deficiência, com frequência também produzem aumento da dependência de outrem e restrição da participação social. As crenças sobre a deficiência, a falta de acesso às informações, a centralização dos serviços e sua reduzida disponibilidade são algumas barreiras apontadas como dificultadoras do acesso à reabilitação. Isso torna premente a elaboração de políticas públicas adequadas, assim como o aumento de recursos com possibilidade de expansão e descentralização das ofertas. Sugere-se, para tanto, a elaboração ou modificação de planos nacionais de reabilitação, que possibilitem infraestrutura necessária e capacitação de profissionais na área, assim como a expansão de programas de pesquisas. (OMS, 2012)

Os elevados custos da reabilitação e dos seus recursos de tecnologia assistiva tornam insuficientes os recursos disponibilizados por diversos países, com vistas ao custeio da infraestrutura necessária para o cuidado adequado, que somado à condição socioeconômica desfavorecida da maioria dos indivíduos com deficiência aprofunda as dificuldades de acesso à reabilitação, assim como de participação social efetiva dos sujeitos. O treinamento de trabalhadores de nível técnico apresenta-se como uma alternativa de baixo custo, suprindo parte das necessidades em reabilitação, estratégia essa adotada em países subdesenvolvidos, cujo número de profissionais de reabilitação é insuficiente. A Reabilitação Baseada na 
Comunidade (RBC) mostra resultados promissores, trabalhando dentro dos limites entre os serviços sociais e de saúde tradicionais. Nas comunidades em que foram implementadas mostrou-se como uma ferramenta importante na inserção social das pessoas com deficiência. Um dos objetivos da RBC é a melhoria das condições socioeconômicas das pessoas com deficiência. É pensada em articulação com serviços especializados, para onde os usuários são encaminhados dependendo das necessidades de reabilitação. (OMS, 2012)

Entretanto, pesquisas evidenciam limites nas ofertas dos trabalhadores de nível técnico, que não conseguem dar respostas às questões mais específicas de reabilitação, como as relacionadas ao bem estar físico que proporcionam aos sujeitos. Em pesquisa envolvendo Gana, Guiana e Nepal (OMS, 2012) aparece a dificuldade dos serviços de RBC no encaminhamento para a reabilitação física, assim como na garantia do acesso aos dispositivos de tecnologia assistiva e aos especialistas. O número reduzido de pesquisas sobre reabilitação aparece como um limitante para outras análises mais aprofundadas.

No Relatório Mundial da Deficiência é citada uma pesquisa realizada no Hospital das Clínicas da Faculdade de Medicina da Universidade de São Paulo (HC-FM-USP), localizado na cidade de São Paulo. Nesse relato, a partir da observação prévia de altos índices de complicações clínicas apresentadas pelos usuários com lesão medular, como consequência de longos períodos em espera para o acesso aos serviços de reabilitação, algumas consultas pontuais de fisioterapia foram realizadas. Esses atendimentos focaram em orientações aos usuários e cuidadores, direcionadas à prevenção de úlceras e deformidades. Obteve como resultado a diminuição dessas complicações secundárias. "Este exemplo indica que países em desenvolvimento com recursos limitados e grande número de traumas podem se beneficiar de estrategias básicas de reabilitação para reduzir as condições secundárias” (OMS, 2012,p.119). Essas são algumas das orientações direcionadas aos países em desenvolvimento.

\section{2 - REORIENTAÇÃO DAS PRÁTICAS EM REABILITAÇÃO NO CENÁRIO POLÍTICO ATUAL}

Qual cuidado estamos propondo e produzindo? Para onde esse processo de repensar as nossas práticas tem nos direcionado e o que produzimos a partir disso? 
É necessário rever as práticas de reabilitação. No entanto, acredito ser necessário alinharmos a processos de análises, que nos auxiliem a colher os resultados e direcionarmos as nossas práticas para ações cuidadoras. Entendo o investimento acadêmico como modo de contribuir com essa qualificação.

No Fórum de Reabilitação é possível identificar alinhamento das falas das participantes com o que vem sendo pautado nacional e internacionalmente sobre o tema. No entanto, outros elementos escapam à isso, presentes nos casos que entram em cena, que ressaltam o encontro das profissionais de saúde e educação com os usuários. O movimento produzido extrapola os limites de exemplificações, para evidenciar um certo modo de operar os conceitos com os casos concretos, que nos impossibilitam fazer afirmações contundentes e universais, pois a cada novo caso, a cada nova pessoa que entra em cena, o conceito se desloca, produzindo outras visibilidades. Expressões como “eu acho", "talvez", "não sei”, são frequentes nas falas. Os encontros com os usuários e as cenas difíceis colocam em análise as nossas escolhas e o nosso modo de operar.

Na tese de doutorado da Terapeuta Ocupacional Maria da Conceição dos Santos de 2017, apresentada à Faculdade de Medicina da USP (FM-USP) com o tema: "Pessoa com deficiência física, necessidade de saúde e integralidade: análise das práticas de reabilitação no SUS", desenvolvida na cidade de Santos, apresenta no seu estudo o modo como vem sendo amplamente discutido o conceito de deficiência e reabilitação no processo de reorientação das práticas, assim como certo olhar, a partir de entrevistas com usuários, sobre o cuidado de fisioterapia à pessoa com deficiência no município citado. Desse modo, acredito que seja possível certo diálogo com o que apresento do Fórum de Reabilitação e com o meu problema de pesquisa.

Por longo período o elemento bio era modo exclusivo de olhar para o processo saúdedoença, assim como para a deficiência (SANTOS, 2017). Partir do entendimento que os fatores sociais produzem interferências as mais diversas muda tudo, muda o conceito de deficiência, muda o modo de entender a reabilitação e pressiona para mudanças nas práticas.

A deficiência foi historicamente definida por referência às noções de normalidade $\mathrm{e}$ incapacidade dos corpos. As práticas de saúde direcionadas para essa população são ainda centradas em uma perspectiva reabilitacional individualizada. Está posto o desafio sociopolítico da incorporação dos direitos humanos no âmbito das práticas assistenciais em saúde e reabilitação. Assim como a elaboração da deficiência como fenômeno complexo e 
multidimensional, que não é exclusivamente social e nem biológico, mas se apresenta na interação de ambos. O modelo social da deficiência, assim como o biológico, apresenta limitações. Desse modo, no cenário dos modelos e das práticas de reabilitação permanece em aberto os debates e as tensões entre as escolas de pensamento. (SANTOS, 2017)

As práticas de saúde têm enfrentado o desafio de superar as limitações em responder às complexas necessidades de saúde da população, que igualmente se impõe às práticas de reabilitação. Partindo do conjunto de necessidades das pessoas com deficiência, novas estratégias são primordiais para superar práticas orientadas para a normatização morfofuncional do corpo com deficiência. A reabilitação carece de aprofundamento acerca das lógicas e racionalidades, que tem orientado o encontro entre profissionais de saúde e usuários, na prestação da assistência no SUS. Então, às ciências da reabilitação fica a incumbência de repensar as práticas assistenciais, incorporando medidas mais abrangentes, como a inclusão da biografia dos sujeitos e do contexto sociocultural. Para tanto, o trabalho em equipe multiprofissional e ações transdisciplinares são possíveis ferramentas de trabalho. (SANTOS, 2017)

No estudo citado, ao apresentar a rede de cuidados à pessoa com deficiência, a autora demonstra uma realidade diferente da Freguesia do Ó e Brasilândia. Em Santos, um maior número de fisioterapeutas compõe as equipes de reabilitação e atenção domiciliar pelo SUS. Dispõe de um serviço municipal de reabilitação e um estadual, o Centro de Reabilitação Lucy Montoro. Na STS FÓ/Brasilândia a única equipe de Atendimento Domiciliar não possui fisioterapeuta. Entretanto, a pesquisadora considera que as ofertas da fisioterapia são bastante pautadas pelo modelo biomédico, não sendo suficiente para acolhimento e cuidado de diversos usuários. Considera que o aumento do número de profissionais não é suficiente para que os usuários sintam-se cuidados, desse modo, propõe que as ofertas e as práticas sejam revistas. (SANTOS, 2017)

A participação social é vital para a funcionalidade humana e bem-estar, tornando-se um conceito central nas ciências da reabilitação e um desfecho positivo do processo de reabilitação. As barreiras arquitetônicas aparecem nos relatos dos usuários como limitantes de autonomia e participação social, evidenciando como dificultam os diferentes acessos. Desse modo, é necessário olhar para as complexas condições socioculturais dessa população, para a infraestrutura dos serviços, com vistas a viabilizar a prestação de assistência em saúde e 
reabilitação na perspectiva da integralidade. São necessárias ações interdisciplinares para a eliminação das barreiras, que viabilizem a inserção social desses usuários. (SANTOS, 2017)

Entretanto, no processo de alta e desligamento de ambos serviços de reabilitação de Santos, como descrito, não está presente a intermediação da inserção dos sujeitos em atividades, apesar de serem encaminhados pelos profissionais. Também não é elaborada a continuidade do cuidado com a UBS. Acredito que, dentre outras, a inserção em uma atividade ou prática corporal é uma das estratégias para efetivação da participação social das pessoas com deficiência, desse modo, produz um entendimento que as ofertas de cuidado para as pessoas com deficiência não são direcionadas para esse fim.

Em paralelo, na Freguesia do Ó e Brasilândia fomos elaborando certo modo de pensar as práticas onde a participação social passa a ser um objetivo importante, no qual vamos empenhando esforços na tentativa de tornar isso efetivamente parte do processo de reabilitação das pessoas com deficiência, ressalto que isso ainda está em construção e vamos encontrando diversas dificuldades para viabilizar essas inserções. Nesse sentido, o agenciamento da participação dos usuários nos equipamentos de cultura, esporte e laser do território é um movimento que estamos investindo esforços e esse é um interesse antigo das profissionais do Fórum. O percurso vai evidenciando a complexidade desse agenciamento, que de início já encontra barreiras arquitetônicas intransponíveis para diversos usuários, como regiões de morro e ruas irregulares no acesso ao Núcleo de Convivência de Idosos ou na inacessibilidade do CEFÓ. Apresenta-se também a dificuldade das trabalhadoras fazerem as visitas, por não conseguirem flexibilidade nas agendas de atendimentos em decorrência da sobrecarga de trabalho, sendo fator limitante para avançarmos nesse mapeamento e agenciamento.

É importante ressaltar que há uma precarização já em curso dos serviços de saúde do SUS que vem se agravando. A PEC 241/2016 que congela o orçamento da saúde e da educação pelos próximos vinte anos, apresenta-se como intensificador dessa precarização (SANTOS, 2017). Considero que o congelamento dos gastos é fator limitante para a expansão de políticas públicas necessárias para a viabilidade de condições efetivas de participação social das pessoas com deficiência. Em São Paulo, a precarização se apresenta bastante avançada em diversos serviços municipais, em especial os que estão sob a gestão da administração direta, devido à falta de contratação de profissionais e de contratos de manutenção de toda estrutura física. 
Para dar continuidade a discussão relacionada à precarização dos serviços e das ofertas em saúde gostaria de retomar o Relatório Mundial da Deficiência, assim como apontar dados estatísticos que delineiam certo cenário político e econômico da cidade de São Paulo. Considerando a pesquisa realizada pelo HC - FMUSP já citada, dentre outras informações presentes, concluo que o Relatório apresenta diferentes propostas de reabilitação para os países com diferentes condições econômicas. Não defendo que devêssemos partir do modelo de países considerados desenvolvidos, nem descredibilizar modos de operar esse processo de cuidado e reabilitação pelos países ditos subdesenvolvidos. O que proponho é olharmos para o lugar onde estamos, no território de saúde citado, considerando que há diversos vetores macro e micropolíticos, que podem ser facilitadores ou barreiras desse processo de pensarmos e praticarmos o cuidado em rede para pessoas com deficiência.

Acredito que o estado de São Paulo, e em particular a cidade de São Paulo, apresenta condições socioeconômicas diferentes dos países subdesenvolvidos e mesmo em desenvolvimento. O município de São Paulo, segundo pesquisa realizada pela Fundação Sistema Estadual de Análise de Dados (SEAD), no ano de 2014 permaneceu em primeiro lugar quando comparado a outros municípios do estado em relação ao tamanho do Produto Interno Bruto (PIB), concentrando sozinho mais de 1/3 (33,8\%) do PIB estadual (Fundação SEAD, 2014). Dados do Instituto Brasileiro de Geografia e Estatística (IBGE) indicam que São Paulo é o município brasileiro com o maior PIB ${ }^{17}$. Também concentra o maior número de hospitais do país e mais de $18 \%$ dos leitos de internação pelo SUS (CONASS, 2013).

$\mathrm{O}$ número de fisioterapeutas inscritos na cidade de São Paulo é $26.056^{18}$. Equivale a aproximadamente 23,1 fisioterapeutas para cada 10.000 habitantes ${ }^{19}$. Apresenta assim maior disponibilidade de fisioterapeutas do que países desenvolvidos, já que essa relação é entre quatro e seis no Reino Unido, Estados Unidos, Canadá, Austrália e Nova Zelândia e pouco maior que 20 na Finlândia. No entanto, no Paquistão, Nigéria, Sri Lanka, Iraque, Egito, Zâmbia, África do Sul, entre outros, o valor da relação cai para maior que zero e menor que dois. (OMS, 2012)

17 Dado fornecido pelo Instituto Brasileiro de Geografia e Estatística (IBGE). Disponível em: https://cidades.ibge.gov.br/brasil/sp/sao-paulo/panorama. Acesso em: 24 de abril de 2019.

${ }^{18}$ Dado disponibilizado pelo Conselho Regional de Fisioterapia e Terapia Ocupacional - Regional 3 (CREFITO3). Disponível em: http://www.crefito3.org.br/dsn/app_site/estpf.asp Acesso em: sete de janeiro de 2019.

${ }^{19}$ Dado também fornecido pelo IBGE no site acima citado. 
Os bairros da Freguesia do Ó e Brasilândia apresentam o total de 407.245 habitantes (SÃO PAULO, 2019), 18 fisioterapeutas trabalham no SUS, dentre serviços especializados de reabilitação e NASF. São 0,44 fisioterapeutas para cada 10.000 habitantes. Esse número é menor se considerarmos os habitantes dos bairros vizinhos que utilizam os serviços de reabilitação do território.

Mesmo nesse cenário, a oferta de cuidado às pessoas com deficiência pelos serviços municipais de reabilitação do SUS em São Paulo assemelha-se a de países em situação econômica inferior à que apresentamos e com menor disponibilidade de profissionais. Esse cenário nega o potencial financeiro de custear essa política pelo município de São Paulo e a disponibilidade de profissionais capacitados para esse cuidado.

Em 2015, o maior número de usuários em espera cadastrados no $S I G A^{20}$ da cidade de São Paulo era por fisioterapia, evidenciando que os fisioterapeutas não conseguem atender grande parcela de pessoas que procuram por seus serviços. Sem negar a presença de diversos fatores na produção dessa demanda, ressalto a falta de investimento, assim como a contratação insuficiente de profissionais, como um projeto político dos gestores públicos, que produz barreira de acesso à reabilitação para inúmeros usuários. $\mathrm{O}$ custeio insuficiente do SUS ao longo dos anos vem se traduzindo em sucateamento dos serviços públicos, que sobrecarrega os trabalhadores. Soma-se a esse cenário a disponibilidade de escassos recursos tecnológicos, tanto referentes aos equipamentos dos serviços de reabilitação, como de tecnologia assistiva aos usuários.

As apostas da gestão municipal também atravessam os serviços de reabilitação e dentre elas destaco os mutirões realizados para avaliação e fornecimento de cadeiras de rodas adaptadas, órteses e calçados, que aconteceram nos anos de 2017, 2018 e 2019. Não contesto a necessidade de fornecimento desses dispositivos de tecnologia assistiva, mas esse processo poderia ser produzido de outros modos. Não houve contratação de profissionais para esses mutirões, ou previsão de pagamento de horas adicionais de serviço. Desse modo, inúmeros fisioterapeutas e terapeutas ocupacionais foram deslocados dos atendimentos, diminuindo o número de vagas aos usuários. O cuidado no processo de fornecimento das tecnologias assistivas nesses mutirões é algo a ser questionado. Considerando que a prescrição de

\footnotetext{
${ }^{20}$ Sistema Integrado de Gestão e Atendimento (SIGA). É o software padrão, desenvolvido pela Prefeitura de São Paulo, para a gestão dos recursos e serviços prestados pelos serviços municipais Sistema Único de Saúde (SUS).
} 
tecnologias assistivas faz parte de um processo complexo de pensar o cuidado de pessoas com deficiência, a indicação adequada se correlaciona com os possíveis usos da mesma. A avaliação desses dispositivos por profissionais que não fazem o acompanhamento terapêutico desses usuários pode resultar em indicação inadequada. Há impossibilidade de acompanhamento do uso desses dispositivos por usuários que não estão vinculados a serviços municipais de reabilitação, ou que residem em outros municípios e mesmo outros estados.

Na cidade de São Paulo ofertamos, através do SUS, próteses, órteses, meios auxiliares de locomoção e cadeira de rodas, mesmo as adaptadas e motorizadas, que são contempladas pela tabela $S U S^{21}$. No entanto, alguns usuários necessitam de outros dispositivos não contemplados, muitas vezes imprescindíveis para a participação social efetiva e melhora das condições de vida, mas a situação socioeconômica desfavorável da população impede a aquisição de tecnologias ofertadas a altos custos pelo mercado da saúde. Ressalto que a reabilitação em uma perspectiva técnico-científica possibilita certas respostas, mas não torna dispensável a abertura para que a vida dos sujeitos entre em cena, na produção de um cuidado compartilhado, assim como a contextualização social e familiar. Retomo a seguir dois casos citados no Fórum de Reabilitação do mês de agosto.

Trata-se dos dois usuários que "rastejam" pelo chão das respectivas casas. É necessário indicar que há limites na descrição dos casos até mesmo pela forma que foram apresentados, que sem a intenção de discutir as ofertas e possibilidades, mas de exemplificar a produção de cuidado no contexto dos sujeitos e das equipes. Eu os retomo olhando em perspectiva outra à que foi apresentada no Fórum de Reabilitação.

O primeiro é o caso de um jovem de 24 anos com diagnóstico de Encefalopatia Crônica Não Evolutiva (ECNE) no nascimento e é um homem "enorme", segundo a descrição. Em decorrência das limitações físicas e dos limites de auxílio de sua mãe não consegue sentar-se em uma cadeira de rodas. Então, adaptou-se ao chão de sua casa, onde realiza todas as Atividades de Vida Diária. Também faz uso do computador e da televisão, faz exercícios e tem uma namorada. Segundo descrito, esse caso mobiliza a equipe de saúde há anos, fizeram as ofertas disponíveis e pensam em alternativas para tentar melhorar a vida dele,

\footnotetext{
${ }^{21}$ Tabela de Procedimentos, Medicamentos e Órteses, Próteses e Meios Auxiliares de Locomoção do SUS é conhecida como tabela SUS, é gerenciada pelo SIGTAP - Sistema de Gerenciamento de Tabela de Procedimentos, Medicamentos e OPM do SUS, que consta no site do DATASUS.
} 
além de terem solicitado ajuda de diferentes profissionais. Em algum momento no Fórum problematizam que talvez não seja um problema ele se "arrastar", se está adaptado e sem queixas, que é uma produção nossa pensar que as pessoas têm que viver dentro de certos modelos. Não pretendo discutir esse modo de olhar porque concordo que produzimos cuidado junto com os usuários e não cabe a nós dizer qual é o modo mais adequado de tocarem suas vidas. Olhando por essa perspectiva nada mais precisaria ser feito se essa não é uma necessidade de saúde manifestada pelo usuário e sua família. No entanto, considerando que a participação social é um objetivo importante no cuidado de pessoas com deficiência, esse é um aspecto que não está contemplado nesse modo de vida. Considerando ainda que as diversas limitações presentes também limitam as possibilidades de produção de desejos, acredito que vale a pena insistir em ofertas. Pensando em dispositivos de tecnologia assistiva, está disponível no mercado guindastes elétricos e manuais para transferências, camas hospitalares elétricas e manuais, entre outros tantos. Será que se pudéssemos ofertar essas tecnologias assistivas ele conseguiria sair do chão? Será que ficar no chão é mesmo escolha? Será que sair do chão possibilitaria a ele circular por outros lugares e produzir de outra maneira sua vida?

O segundo caso é de um senhor que se "rasteja" dentro da própria casa e o acesso aos diversos cômodos é por escadas, o que somado às deformidades em membros inferiores inviabiliza o uso de cadeira de rodas. Nesse caso o pedido do usuário é de escuta e conversa, não de dispositivos auxiliares. Atualmente, cadeiras de rodas que sobem e descem degraus estão disponíveis no Brasil para venda, apesar de apresentarem limites de uso e talvez não fossem adequadas para o usuário citado, mas há outros produtos no mercado visando esse tipo de acesso.

No Reino Unido e na Irlanda o Estado disponibiliza verba para adaptação dos domicílios de pessoas com deficiência, onde são realizadas conversões em banheiros, construção de anexos, elevadores, entre outras. Em pesquisa realizada para avaliação do impacto dessas adaptações, junto às pessoas cujas casas foram adaptadas, concluiu-se que esse parece ser um modo altamente eficaz de utilizar o dinheiro publico, justificando o investimento em saúde e em recursos para reabilitação, visto que, em sua maioria, houve transformação nas vidas das pessoas após as reformas. "Antes das adaptações, as pessoas usavam palavras como 'prisioneiro', 'humilhante' e 'receoso' para descrever suas situações. Após, eles se descrevem como 'independentes', 'uteis' e 'confiantes' (...)" (OMS, 2012, p.104). 
Em São Paulo, como explanado no Fórum, a verba disponível com essa finalidade é limitada e para fins específicos, como corrimões no banheiro, entre outros, não contempla reformas nas residências. Se conseguíssemos fazer outras ofertas, seria mesmo escolha subir degraus se "rastejando"?

O trecho citado a seguir é parte do texto de Stephen Hawking para o Relatório Mundial da Deficiência:

A deficiência não precisa ser um obstáculo para o sucesso. Durante praticamente toda a minha vida adulta sofri da doença do neurônio motor. Mesmo assim, isso não me impediu de ter uma destacada carreira como astrofísico e uma vida familiar feliz. Ao ler o Relatório Mundial sobre a Deficiência, encontro muitos aspectos relevantes para a minha própria experiência. Pude ter acesso a assistência médica de primeira classe. Tenho o apoio de uma equipe de assistentes pessoais que me possibilita viver e trabalhar com conforto e dignidade. A minha casa e o meu lugar de trabalho foram tornados acessíveis para mim. Especialistas em informática puseram à minha disposição um sistema de comunicação de assistência e um sintetizador de voz que me permitem desenvolver palestras e trabalhos, e me comunicar com diferentes públicos.

Mas sei que sou muito sortudo, em muitos aspectos. Meu sucesso em física teórica me assegura apoio para viver uma vida que vale a pena. E claro que a maioria das pessoas com deficiência no mundo tem extrema dificuldade até mesmo para sobreviver a cada dia, quanto mais para ter uma vida produtiva e de realização pessoal.

Professor Stephen W. Hawking ( OMS, 2012, p. ix - preâmbulo)

\section{3 - DIALOGANDO COM OUTRAS PERSPECTIVAS PARA REVER AS PRÁTICAS DE CUIDADO E REABILITAÇÃO}

O corpo constantemente afetado por cada pedaço de mundo que encosta produz constantemente novos mundos. A cada momento da vida novos problemas são inventados levando o corpo a inventar novas formas. (LIBERMAN e LIMA, 2016, p. 165)

No livro "Movimentos Micropolíticos em Saúde, Formação e Reabilitação" (KASTRUP e MACHADO, 2016) é em uma perspectiva outra que o conceito de reabilitação é discutido, assim como as práticas de cuidado para pessoas com deficiência. O desejo, o cuidado, a vida, a produção de mundos são postos como objetivos, extrapolando os limites das outras propostas, dando abertura para a produção de vida e de mundos e coloca o cuidado em foco, delineando um outro plano para a reorientação das práticas. A reabilitação não é um fim com um objetivo definido a priori, mas um processo que dá suporte à constituição de um 
corpo-outro, que emerge com a deficiência. Ressalta o desafio de produzir potência de vida, discute a multiplicidade de fatores envolvidos na produção da deficiência como uma desvantagem, dentre eles os fatores políticos, os econômicos, os sociais, os culturais e os subjetivos.

O modo de pensar a reabilitação, assim como o próprio termo, é colocado em análise. A palavra Reabilitar acessa vários pressupostos, sendo o primeiro a necessidade de habilitar, que considera que uma pessoa está temporariamente ou definitivamente desabilitada. No diálogo que Lima e col (2016) estabelecem com Canguilhem (2000), problematizam a normatização do corpo produzida pela medicina e a própria ideia de reabilitação conota negativamente a deficiência, em que o caráter da falta, perda ou incapacidade são privilegiadas nessa perspectiva. Então as deficiências e desabilidades vão sendo inclusive produzidas pelos dispositivos de tratamento, que definem "realidades corpóreas como prejuízos e incapacidades". O segundo pressuposto é a ideia de voltar atrás estabelecida pelo prefixo re, que pressupõe ser possível retornar à uma certa condição funcional anterior ou de restituir uma capacidade perdida. "A experiência de adquirir uma deficiência tem um caráter de acontecimento e de irreversibilidade", sendo "impossível voltar a uma condição anterior" (LIMA e col, 2016, p.156).

Essas problematizações do termo reabilitar aparecem com a proposta de renomear o que vem sendo produzido, como resistência a certas políticas do corpo que incidem violentamente sobre a vida. Nesse sentido, fazem a diferenciação entre um modelo de reabilitação denominado de funcionalista, que produz práticas voltadas para a correção do corpo, dos gestos, dos movimentos e dos comportamentos considerados desviantes da norma, reabilitação essa muitas vezes "dissociada das vicissitudes da vida cotidiana". "Desconsiderando a multiplicidades de fatores políticos, econômicos, socio-culturais, subjetivos e afetivos que compõem a dimensão de desvantagem das deficiências e desabilitações" (LIMA e col, 2016, p.155). "Ao combater gestos e movimentos desviantes, padronizam os modos de ser, de agir e de estar no mundo" (LIMA e col, 2016, p.156).

Em contraposição, propõem uma abordagem inventiva da reabilitação, entendida como um processo de experimentação das possibilidades que um corpo carrega. Apresentando-se não como a solução de um problema, mas como um campo de exploração de possibilidades, inclusive da produção de novos problemas, no exercício de um certo caminhar que nunca se experimentou antes. Nessa perspectiva, as práticas são capazes de produzir um 
processo de reinvenção existencial, "construindo bifurcações no vivido e criar novas conexões com o mundo" (LIMA e col, 2016, p.156). Isso possibilita a recuperação de sentido que leva ao refazimento de um contorno que havia sido rasgado, mas agora "um novo contorno marcado pela ferida que cicatriza" (LIBERMAN e LIMA, 2016, p.173). Nessa perspectiva, a "reabilitação física" compõe-se com a experimentação de outros modos de viver, de fazer as atividades, de relacionar-se com as pessoas, em um processo intenso e delicado de deslocamentos da subjetividade, onde outros modos de pensar, sentir e agir são inventados (LIBERMAN e LIMA, 2016).

Experienciamos fins de mundo em alguns momentos na vida. Então, somos arremessados para zonas que são mescladas de dor e desconhecido. Na perspectiva da deficiência como um acontecimento, onde a vida é separada em um antes e um depois, acontece a ruptura de uma teia de sentidos que joga as pessoas para "fora de si mesmas", vivenciamos o morrer de um corpo e o nascer de outro. O acontecimento como ruptura é condição para que a vida se reinvente. O que está posto é a finitude de um modo de viver e a emergência de outro, com novos encontros, imagens e impulsos. Esse corpo-outro produz uma série de problematizações que não existiam antes, o que possibilita a reinvenção de mundos e de vidas, fazendo-se presente o desejo de perseverar na existência. Então cabe às práticas corporais se articularem com os territórios existenciais. (LIBERMAN e LIMA, 2016)

$\mathrm{O}$ acontecimento que provoca a deficiência produz pequena morte no corpo e no modo de vida. Fica então o desafio para a reabilitação de produzir novas conexões, assim como a possibilidade de reinvenção de modos de vida com a produção de um novo corpo, que se relaciona de um modo outro com o mundo e com as pessoas. As tecnologias assistivas e a reabilitação são colocadas à disposição para ampliar as possibilidades desse corpo, visando à recuperação de uma processualidade vital, refazendo contornos, possibilitando a redescoberta da alegria de viver e a reinvenção de vida. Então esses refazimentos não são com a intenção de voltar atrás, mas de reconectar os usuários a uma potência de vida perdida ou até mesmo nunca experimentada. A exigência de transformação existencial inviabiliza o uso do conceito de adaptação, pois não dá conta da contingência estabelecida. (LIBERMAN e LIMA, 2016)

A reabilitação é pensada diferente ao que foi anteriormente citado. As autoras utilizam a expressão re-habilita-ação, considerando que propõem outros sentidos para a prática, que tange aqui outras questões, compondo-se com o processo de produção de vida, onde 
diferentes relações vão-se delineando a partir desse corpo-outro. Desse modo, a deficiência vai sendo entendida de outro modo também.

Acredito que essa perspectiva dialoga com um processo de rever as práticas na micropolítica dos encontros na qual outro campo de problemas vai se constituindo. Quando se discute o modelo biológico e o modelo social da deficiência, pouco se diz sobre como isso atravessa as pessoas. As questões elaboradas pelas autoras dialogam com questões também produzidas pelas trabalhadoras do Fórum de Reabilitação. Onde em diversos momentos o modo de cuidar e reabilitar são problematizados.

\footnotetext{
a quem se busca reabilitar e qual a direção das práticas de reabilitação? (LIMA e col, 2016, p.157)

Será que o efeito do tratamento assim orientado seria algo mais que manter o sujeito indefinidamente vinculado a processos longos e especializados, avaliações e treinamentos, nunca chegando a ser considerado habilitado? Resumindo: a meta reabilitativa seria alcançável? Em que medida? (LIMA e col, 2016, p.156)
}

Discutimos as necessidades de saúde dos usuários, assim como o pedido de alguns por "reabilitação eterna" ${ }^{22}$. Problematizamos como fazer nesses casos, considerando que algumas pessoas vão andar de outra forma, falar de outra forma e nunca serão enquadradas naquilo que é considerado normal. Uma provocação feita foi: "e nesses casos?". Nesse sentido, nos colocamos o mesmo problema, ou seja, se a meta reabilitativa é alcançável. Discutimos os efeitos dos diferentes modos de pensar a reabilitação e a deficiência na vida das pessoas.

No Fórum aparecem outros questionamentos relacionados à reabilitação. "a gente vai pensar na reabilitação só junto da pessoa ou a gente vai pensar no entre?" "O que é reabilitação? Como que a gente pratica isso? Como que isso está presente na unidade?”. No mesmo sentido, foram aparecendo questionamentos a partir do encontro com os usuários, onde as profissionais se interrogaram como produzir junto com os mesmos o projeto terapêutico. No projeto terapêutico dele priorizaria possibilitar bons momentos? Ou não insistir no uso da órtese é negligenciar?

Em algum momento do Fórum, quando uma das profissionais da educação questiona até onde deveríamos insistir em certo modo de fazer, outra participante diz: "espero que você continue com essa dúvida". Desse modo, acredito que as provocações produzidas por essas

\footnotetext{
${ }^{22}$ Termo que utilizamos no Fórum de modo provocativo, nos referindo a pedidos de usuários por reabilitação, que frequentemente possuem como meta que seus corpos retornem a uma condição morfo-funcional anterior, e consideram que é necessário continuarem por tempo indefinido nos serviços de reabilitação.
} 
questões nos deslocam. A cada novo usuário as respostas não estão dadas, não há uma prescrição previamente elaborada, ou não deveria haver. No entendimento que a produção de cuidado é um processo, os projetos terapêuticos precisam com frequência serem elaborados e reelaborados em conjunto com os usuários e familiares, dando abertura para que as questões produzidas a partir desse encontro sejam reatualizadas ou inventadas outras, que estejam alinhadas com os problemas presentes em dado contexto singular. 


\section{6 - CONSIDERAÇÕES FINAIS}

$\mathrm{Na}$ apresentação proponho-me a produzir outras visibilidades sobre a rede de cuidados em saúde à pessoa com deficiência, na Freguesia do Ó e Brasilândia, diferente daquelas produzidas pelos números. Esse percurso com o Fórum foi me permitindo visualizar a potência daquilo que estamos produzindo na rede, a partir das práticas das diferentes profissionais envolvidas, o que não estava presente nas publicações sobre o tema de cuidado da pessoa com deficiência. O Fórum também evidencia a importância da rede para atendermos à complexidade que é o mundo do cuidado. Encontrei um considerável número de estudos relacionados à reorientação das práticas de fisioterapeutas, que visam à inserção desses profissionais na Atenção Básica, mas pouco se discute sobre as práticas na Atenção Especializada, no sentido de qualificar o que vem sendo praticado, assim como de pensar os sentidos da reabilitação. Ressalto a necessidade de mais pesquisas que dialoguem com o que vem sendo produzido no cotidiano dos serviços de saúde, adotando a reabilitação na Atenção Especializada como problema.

Outra importante consideração sobre esta pesquisa é ser operada por uma trabalhadora da saúde no encontro com outras trabalhadoras, permitindo que o cuidado apareça sobre um plano diferente do habitualmente tangenciado pelos estudos, considerando também que as vozes dos trabalhadores de saúde são pouco frequentes na elaboração e implementação das políticas públicas. Desse modo, são necessárias mais pesquisas cujo campo é o cotidiano das práticas, pois possibilitam ir além da reprodução e reafirmação daquilo que foi produzido como política em um plano formal. Possibilita a reelaboração da política a partir das práticas, do cotidiano do trabalho e do encontro com os usuários.

De modo geral, os gestores incidem principalmente no plano da formalidade, quando não se conectam com o cotidiano do trabalho. A relação intergestores fabricou um mundo paralelo de planos e relatórios que consomem parte considerável da energia dos trabalhadores, mas que pouco se alimenta ou oferece subsídios para a vida do cotidiano das unidades de saúde. Desse modo, a avaliação dos processos de trabalho, devido à sua riqueza e complexidade, convoca como investigadores os próprios sujeitos do trabalho, que podem "dar voz ao mundo em que está imersa a sua práxis produtiva”, com seus atravessamentos e transversalidades, onde aparece a potência das relações entre sujeitos na produção de processos de subjetivação e de modos de caminhar a vida. (FEUERWERKER, 2014, p.32) 


\begin{abstract}
Mas há muitos outros planos operando na constituição das unidades. Há o plano do senso comum em nossa sociedade medicalizada (pergunte a qualquer um na rua o que é e para o que serve uma unidade de saúde e receberá respostas bastante precisas e regulares). Há o plano da subjetivação produzida pelas indústrias de equipamentos e medicamentos e a produção de necessidades em suas interfaces com as políticas. Há outro plano, que é o das corporações e suas disputas sobre o trabalho em saúde, profundamente imbricado com o anterior. Há um plano político conformado pelo que se pensa sobre o direito à saúde - na sociedade e entre trabalhadores, gestores e usuários das unidades de saúde. Há outro plano conformado pelas histórias de vida de cada um dos trabalhadores das unidades. Há o plano conformado pelos turbilhonamentos provocados pelo encontro entre as diferentes culturas e ciência oficial em relação à saúde. Outro, pelas religiões. Outro pelas condições materiais de trabalho e pelas possibilidades de conexão em rede das unidades. Todos esses planos operam em relação aos trabalhadores e também em relação aos usuários. Acrescentese em relação aos últimos, a história da construção da saúde em seu território (físico, neste caso), se se trata de uma população com fortes conexões coletivas ou não, em situação de muitas necessidades insatisfeitas ou não, com alternativas de acesso a serviços ou não. E por aí afora. (FEUERWERKER, 2014, p.64)
\end{abstract}

Trabalhadores e usuários possuem ideias, concepções e valores acerca de saúde e do trabalho em saúde, que são fabricados de modo complexo, atravessadas pelos diversos planos acima mencionados e $\operatorname{logo}$ não são naturais, são fabricados histórica e socialmente. Os trabalhadores fazem uso dos seus espaços de autonomia para orientar as práticas como lhes parece apropriado segundo o contexto, seus valores e ou interesses, mas também das afecções produzidas no encontro com os usuários. Dessa maneira, tomam decisões e "sempre poderiam fazer de outro modo". (FEUERWERKER, 2014, p.67)

Fica evidente ao longo da dissertação e mesmo no Fórum, meu incômodo com a condição que temos de produzir ofertas e como a partir disso alguns modos de cuidado vão sendo pensados e elaborados. Não podemos focar naquilo que falta e então vamos "tocando o serviço" do jeito que é possível, mas há limites nesse fazer. Acredito que seja necessário olhar para os limites estabelecendo como objetivo o cuidado integral às necessidades de saúde dos usuários. Discutir "as faltas" é importante para fazermos disputas na produção de ofertas, assim como para podermos elaborar, em rede, para onde o cuidado que estamos produzindo está sendo direcionado.

“O SUS que fabricamos tem a ver com o SUS que dizemos querer?" (FEUERWERKER, 2014, p.78) 
Essa provocação, em diálogo com uma questão minha (Qual cuidado estamos produzindo?) acompanhou-me durante o percurso da pesquisa. Sem a intenção de responder às mesmas, reforço a necessidade de continuarmos investindo esforços na qualificação da reinvenção das práticas que estamos operando, que em decorrência da complexidade e do longo percurso para tal, não se encerra por aqui. Proponho colocarmos em análise os objetivos e as consequências desse processo, em diálogo com o que já vem sendo produzido em outros estudos, como nos de autores aqui referenciados, dentre outros.

Pensando em caminhos possíveis, acredito que a conversa sobre a consolidação do SUS dialogue com essas questões, já que o SUS foi uma conquista, junto com a Constituição Federal de 1988. Porém há muitas disputas para a sua consolidação, dentre elas o subfinanciamento com verba de custeio menor do que a disponível para a iniciativa privada (MERHY, 2012). A saúde no Brasil está desinvestida pelos projetos atuais de governo, sendo aprovadas leis e políticas que colocam em risco o direito à saúde, como apontado por diversos autores (GRISOLIA, 2017; SANTOS, 2016; CAMPOS e col, 2016; MENDES et al, 2016). Isso vem contribuindo para a ampliação da iniciativa privada e mercantilização da saúde, ocultando o SUS como política social (MENDES et al, 2016). Diversas são as dificuldades enfrentadas, como citadas a seguir. (MENDES et al, 2016)

\footnotetext{
(...) a permanência entre a tradição dos sistemas nacionais e o modo liberal/privado na organização do cuidado à saúde, o que tem contribuído para ambiguidades discursivas e pragmáticas garantindo a sobrevivência do ideário liberal/privatista; o contexto neoliberal desfavorável às políticas públicas, que repercute na responsabilidade sanitária de cada ente federado; a cultura patrimonialista predominante na administração pública brasileira e a precária política de pessoal, uma vez que a gestão participativa ainda é uma potência pouco explorada, considerando que a população e os trabalhadores têm dificuldade para ocupar os espaços de cogestão legalmente constituídos. (MENDES et al, 2016, p.24)
}

Em 2016, Campos e colaboradores publicaram um artigo sobre o Seminário "Direito à Saúde: o SUS está em risco?", realizado na Faculdade de Ciências Médicas (FCM) da Universidade Estadual de Campinas (Unicamp), organizado pelo Coletivo de Estudos e Apoio Paideia. Enfatizam o momento frágil que presenciamos, onde o avanço neoliberal coloca em risco a consolidação do SUS como política social de fomento à cidadania em favor da contraproposta de efetivar-se como uma política assistencial de caráter residual. A falta de recursos para custeio do SUS, assim como a presença da iniciativa privada associada à 
renúncia fiscal, são fatores, dentre outros, que comprometem o direito à saúde. (CAMPOS e col, 2016)

No mesmo sentido, Feuerwerker (2014) considera que, apesar de diversos acúmulos, o SUS real ainda se distancia das propostas da reforma sanitária e que suas fragilidades colocam em risco a sua legitimidade política e social. Ressalta que é permanente a disputa pela concepção de saúde como direito, assim como pelas maneiras de construí-la. Considerando que a Reforma Sanitária ao associar a ideia de democracia à defesa da igualdade (universalidade e equidade), possibilitou que a saúde passasse por uma re-conceitualização, em que o social passou a ter abertura no entendimento do processo saúde-doença. Foi então adotada a perspectiva da atenção integral às necessidades de saúde da população, possibilitando construir o entendimento da saúde como um direito. Para tanto, o trabalho em equipe passa a ser valorizado, assim como a participação ativa do usuário na construção da saúde. (FEUERWERKER, 2014)

A concepção de saúde e dos direitos na nossa sociedade, assim como a organização da gestão, a produção da política e o modelo tecnoassistencial proposto são elementos críticos na fabricação do SUS, pois interferem na resistência à medicalização e ao modelo de saúde hegemonicamente adotado. Desse modo, é indispensável à transformação dos modos de organizar a saúde, tanto pela "necessidade de qualificar o cuidado por meio de inovações produtoras de integralidade da atenção, diversificação da utilização das tecnologias de saúde e articulação da prática dos diferentes profissionais e esferas da assistência", quanto pela necessidade de aumentar a eficiência no uso dos escassos recursos do SUS, considerando que o modelo hegemônico de atenção à saúde, com seus altos custos, não é capaz de atender às necessidades de saúde da população (FEUERWERKER, 2014, p.80). As práticas profissionais estão imbricadas com a produção de cuidado em saúde. Um "algoritmo" proposto é partir da questão "alguém que está sendo cuidado está ampliando ou diminuindo suas redes de conexões existenciais?" (FEUERWERKER, 2014, p.58). Desse modo, quando o cuidado amplia redes de conexão existencial, então produz mais vida, do contrário, o acesso ao cuidado pode produzir "barreiras para um viver mais qualificado" (FEUERWERKER, 2014, p.58).

Considero que neste momento de repensar a reabilitação e o cuidado à pessoa com deficiência no SUS, no cenário político atual, é oportuno nos colocarmos a questão: O que a gente precisa refazer, retomar, rever desses 28 anos de SUS? Uma possível estratégia é 
retornar aos autores clássicos e voltar no tempo com Maria Cecília Donnangelo, para tentar entender o que nos cabe neste momento, podendo ser um dos caminhos para a qualificação das propostas de reorientação das práticas, ajudando a problematizar os direcionamentos das políticas. É oportuno também voltar para tentar compreender: O que não fazer ou o que não foi feito e podemos inventar?

No encontro com Maria Cecília Donnangelo, em sua tese de livre-docência (DONNANGELO e PEREIRA, 2011), pude elaborar esse processo que vivenciamos na Freguesia do Ó e Brasilândia de reorientação das práticas. Donnangelo, assim como outros autores, contribui com a discussão das práticas em saúde e exemplifica o quão complexo é esse cenário, assim como analisa o processo de extensão da prática médica e a medicalização da sociedade. A necessidade de aprofundamento desse estudo, a complexidade e extensão do tema me impossibilitaram desenvolver um diálogo com Donnangelo e Pereira (2011) nesta dissertação.

Gostaria, no entanto, de fazer alguns apontamentos. Essa aproximação com Donnangelo e Pereira (2011) aparece como um disparador de certa leitura que faço do Fórum, possibilitando a comunicação entre a minha prática e o que é o Fórum, em certo modo de fazer rede e conexões. Isso é uma dimensão do trabalho dela, já que ainda está muito viva quando se pensa nas práticas, nas redes e nas instituições. Nessa minha leitura, pensando na Reabilitação Baseada na Comunidade, acredito que o estudo de Donnangelo e Pereira (2011) poderia cintribuir para análise desse processo, fazendo, talvez, um paralelo com a Medicina Comunitária americana, desenvolvida na década de 1960.

Faço esses apontamentos evidenciando que os diferentes modos de pensar o cuidado em saúde adotam perspectivas diversas. Algumas são mais alinhadas com a produção da saúde como direito e de um SUS Universal, com atendimento integral das necessidades de saúde de toda a população brasileira. Em contraponto, há a perspectiva de uma saúde ofertada pelo Estado somente à população pobre, que proporciona certa assistência, mas com simplificação das ofertas e consequente redução de custos, que não visam ao atendimento integral das necessidades em saúde. Considero que a integralidade do cuidado só é possível em uma rede de saúde composta por diferentes possibilidades de ofertas que contemple: atendimento especializado, cirurgias, internações hospitalares, reabilitação, dispositivos de tecnologia assistiva, dentre outros. Isso não prescinde de debates acerca da racionalização dos usos dessas ofertas, considerando que as necessidades em saúde sofrem interferência, dentre 
outras, da indústria de equipamentos em saúde e da indústria farmacêutica. Vale ressaltar que o sujeito precisa ser considerado de modo singular, envolvido pelo contexto socio-políticoeconômico-familiar.

Desse modo, a qualificação do processo de reorientação das práticas é imprescindível para que ele seja norteado pela produção de cuidado e vida, assim como de reafirmar a saúde como um direito e a autonomia dos usuários que possibilite ampliação de suas redes de conexões, no atendimento integral às necessidades de saúde das pessoas com deficiência. Para tanto, necessitamos encher nossas caixas com ferramentas que nos auxiliem nesses objetivos, em diálogo com autores que possam contribuir com esse processo. 


\section{7 - REFERÊNCIAS}

ABRAHÃO, A.L.; MERHY, E.E.; GOMES, M.P.C.; TALLEMBERG, C.; CHAGAS, M.S.; ROCHA, M.; SANTOS, N.L.P.; SILVA, E.; VIANNA, L. O pesquisador IN-MUNDO e o processo de produção de outras formas de investigação em saúde (a título de fechamento, depois de tudo que escrevemos). In: GOMES, M.P.C.; MERHY, E.E (Orgs.). Pesquisadores IN-MUNDO: um estudo da produção de acesso e barreira em saúde mental. $1^{\text {a }}$ Edição; Porto Alegre: Editora Rede Unida, 2014.

ALMEIDA, I.S. Apoio matricial dos Centros de Atenção Psicossocial à Atenção Básica: investigando a experiência no SUS São Paulo. Dissertação de Mestrado. Campinas: Universidade Estadual de Campinas. 2015

ANDRADE, D.; ISHIDA, R; JÓIA, J.H.; TRENCHE, M.C.B. Implementação da rede de saúde na região da Freguesia do Ó e Brasilândia. In: VINCENTIN, M.C.G.; TRENCHE, M.C.B.; KAHHALE, E.P.; ALMEIDA, I.S. (Org). Saúde Mental, Reabilitação e Atenção Básica: Encontros entre Universidade e Serviços de Saúde. São Paulo: Artgraph; 2016.

AZEVEDO, B.M.S.; CALSANI, L.P.; SOUZA, T.P.; REIS, B.M.; CARVALHO, Y.M.; CARVALHO, S.R.; FERIGATO, S.; TEIXEIRA, R.R.; EICHELBERGER, M. A Produção de Redes de encontros e a Produção de Saúde no SUS. Anais do $2^{\circ}$ Congresso Brasileiro de Política, Planejamento e Gestão em Saúde, 01 a 03 de outubro de 2013, em Belo Horizonte MG.

CAMPOS, M.F.; SOUZA, L.A.P; MENDES, V.L.F. A rede de cuidados do Sistema Único de Saúde à saúde das pessoas com deficiência. Revista Interface: comunicação, educação e saúde. Botucatu, v.19, n.52, p.207-210, 2015.

CAMPOS, G.W.S.; BEDRIKOW, R.; SANTOS, J.A.; TERRA, L.S.V.; FERNANDES, J.A.; BORGES, F.T. Direito à saúde: o Sistema Único de Saúde (SUS) está em risco? Revista Interface: comunicação, saúde e educação, Botucatu, v.20, n.56, p.261-266, 2016.

CARDOSO, J.S.. OLIVEIRA, A.E.F.; GARCIA, P.T. (Org). Redes de Atenção à Saúde: Rede de Cuidado à Pessoa com Deficiência. São Luís: EDUFMA, 2017.

CERQUEIRA, P.; MERHY, E.; SILVA, E.; ABRAHÃO, A.L.; VIANNA, L.; ROCHA, M.; SANTOS, N.; CHAGAS, M.; TELlEMBERG, C.; SANTOS, M.T.; CARLA, A. Uma pesquisa e seus encontros: a fabricação de intercessores e o conhecimento como produção. In: GOMES, M.P.C.; MERHY, E.E. Pesquisadores IN-MUNDO: um estudo da produção de acesso e barreira em saúde mental. 1ª Edição; Porto Alegre: Editora Rede Unida, 2014.

CORDEIRO, M. P. Nada Sobre Nós Sem Nós: Os Sentidos de Vida Independente para os Militantes de um Movimento de Pessoas com Deficiência. Pontifícia Universidade Católica de São Paulo, São Paulo, 2007.

DONNANGELO, M.C.F.; PEREIRA, L. Saúde e Sociedade. São Paulo, 2ª ed. 2011. 
FEUERWERKER, L. C. M. Micropolítica e saúde: produção do cuidado, gestão e formação. Porto Alegre: Rede UNIDA, 2014. (Coleção Micropolítica do Trabalho e o Cuidado em Saúde).

GOMES, M.P.C.; MERHY, E.E. Apresentação. In: Pesquisadores IN-MUNDO: um estudo da produção de acesso e barreira em saúde mental. $1^{\text {a }}$ Edição; Porto Alegre: Editora Rede Unida, 2014.

GRISOLIA, L.M. Fórum de Saúde e Produção do Comum: o caso de um Fórum da Rede de Atenção Psicossocial do Município de São Paulo. Dissertação de Mestrado. Pontifícia Universidade Católica de São Paulo, São Paulo, 2017.

HABERLAND, R.; PAVAM, C.; SANTA CRUZ, L.; JOIA, J.H.; OLIVEIRA, A.; ROCHA, P.R.; TRENCHE, M.C.B. O fazer coletivo nas políticas de saúde da FÓ/Brasilândia (SP): fóruns, redes, grupalidades. Distúrbios da Comunicação, São Paulo, v. 29, n.4, p.793-808, dezembro, 2017.

KASTRUP, V.; MACHADO, A.M. (Org) Movimentos Micropolíticos em Saúde, Formação e Reabilitação. Curitiba: Editora CRV, 2016.

LIBERMAN, F; LIMA, EA. Seção III: Subjetividade e Reabilitação - Corpos em Composição com Acontecimentos: imagens e notas sobre um processo de re-habilita-ação. In: KASTRUP, V.; MACHADO, A.M. (Org) Movimentos Micropolíticos em Saúde, Formação e Reabilitação. Curitiba: Editora CRV, 2016.

LARROSA BONDÍA, J. Notas sobre a experiência e o saber de experiência. Revista Brasileira de Educação. Rio de Janeiro, v. jan,fev,mar, abr, n.19, p. 20 - 29. 2002

LIMA, E.A.; LIBERMAN, F.; POZZANA, L.; KASTRUP, V. Seção III - Subjetividade e Reabilitação: Pensando uma reabilitação inventiva. In: KASTRUP, V.; MACHADO, A.M. (Org) Movimentos Micropolíticos em Saúde, Formação e Reabilitação. Curitiba: Editora CRV, 2016.

MENDES, V.M.; CARVALHO, Y.M.; BRANDÃO, F.F.F.. Nós, com os outros e o SUS: uma perspectiva micropolítica do cuidado para além da atenção básica. In: WACHS, F; ALMEIDA, U.R.; BRANDÃO, F.F.F. (Orgs.). Educação Física e Saúde Coletiva Cenários, experiências e artefatos culturais. Porto Alegre: Rede Unida, 2016. p. 23 -46.

MENDES, V.M.; CARVALHO, Y.M.; Sem começo e sem fim... com as práticas corporais e a Clínica Ampliada. Revista Interface: comunicação, educação e saúde. Botucatu, v. 19, n.54, p.603-613, 2015. [online].

MERHY, E. E. Desafios de desaprendizagens no trabalho em saúde: em busca de anômalos. In: LOBOSQUE, A. M. (Org.). Caderno Saúde Mental: Os desafios da formação. Belo Horizonte: Escola de Saúde Pública de Minas Gerais, 2009. v. 3. 
MERHY, E. Saúde e Direitos: tensões de um SUS em disputa, molecularidades. Revista Saúde e Sociedade. São Paulo, v.21, n.2, p.267-279, 2012.

MERHY, E.E.; GOMES, M.P.C.; SILVA, E.; SANTOS, M.F.L.; CRUZ, K.T.; FRANCO, T.B. Redes Vivas: multiplicidades girando as existências, sinais da rua. Implicações para a produção do cuidado e a produção do conhecimento em saúde. Revista Divulgação em saúde para debate. Rio de Janeiro, n.52, p.153-164, outubro, 2014.

NOGUEIRA, Roberto P. Pessoal de saúde: a discussão teórica e a produção científica sobre o tema. In: NUNES, Everardo D.; GARCÍA, Juan César. As Ciências Sociais em saúde na América Latina: tendências e perspectivas. Brasília: OPAS, 1985, p. 407.

PEREIRA, L. Maria Cecília Donnangelo: seis lembranças e um depoimento. Medicina, Cultura \& Ciência - Revista da Associação Médica Brasileira. P. 1-23, 1983.

PEREIRA, R. Diversidade funcional: a diferença e o histórico modelo de homem-padrão. História, Ciências, Saúde - Manguinhos, Rio de Janeiro, v.16, n.3, jul.-set. 2009, p.715728.

RIGHI, L.B. 2006. Produção de Redes de Atenção à Saúde: acordos, confrontos e reparos. In Pasche, D.F.; Cruz, I.B.M. A Saúde Coletiva: Diálogos Contemporâneos. Ijuí: Unijuí, 2006, pp. 73-92.

ROCHA, V.M.; CENTURIÃO, C.H. Profissionais de saúde: formação, competência e responsabilidade social. In.: FRAGA, A.B.; WACHS, F. (Org). Educação Física e Saúde Coletiva: Políticas de Formação e Perspectivas de Intervenção. Rio Grande do Sul: Editora UFRGS, $1^{\text {a }}$ Ed., 2007.

ROSA, EZ; PINTO, RS; VICENTIN, MCG; SILVA, DAB. O Território Sanitário da Freguesia do Ó/Brasilândia e o lugar do território na integração ensino-serviço. In: VINCENTIN, M.C.G.; TRENCHE, M.C.B.; KAHHALE, E.P.; ALMEIDA, I.S. (Org) Saúde Mental, Reabilitação e Atenção Básica: Encontros entre Universidade e Serviços de Saúde. São Paulo: Artgraph, 2016.

SANTOS, M.C. Pessoa com deficiência física, necessidade de saúde e integralidade: análise das práticas de reabilitação no SUS. Tese de doutorado. Faculdade de Medicina da Universidade de São Paulo. São Paulo, 2017.

TEIXEIRA, R.R. As redes de trabalho afetivo e a contribuição da saúde para a emergência de uma outra concepção de público. Working-paper apresentado na Research Conference on: Rethinking "the Public" in Public Health: Neoliberalism, Structural Violence, and Epidemics of Inequality in Latin America Center for Iberian and Latin American Studies University of California, São Diego, abril de 2004. 
VINCENTIN, MCG; TRENCHE, MCB; KAHHALE, EP; ALMEIDA, IS. Saúde Mental, Reabilitação e Atenção Básica: Encontros entre Universidade e Serviços de Saúde. Ed. Artgraph, São Paulo, 2016a.

VINCENTIN, MCG; TRENCHE, MCB; PUPO, AC. Introdução. In. Saúde Mental, Reabilitação e Atenção Básica: Encontros entre Universidade e Serviços de Saúde. Vincentin, MCG e; Trenche, MCB; Kahhale, EP; Almeida, IS (Orgs.). Ed. Artgraph, São Paulo, 2016b.

\section{1 - OUTRAS FONTES DE PESQUISAS}

BRASIL. Ministério da Saúde. Ministério da Educação. Pró-saúde: Programa Nacional de Reorientação da Formação Profissional em Saúde. Brasília, 2005 (Série C. Projetos, Programas e Relatórios).

BRASIL. Ministério da Saúde. Secretaria de Atenção à Saúde. Política Nacional de Saúde da Pessoa Portadora de Deficiência. Brasília: Editora do Ministério da Saúde (Série E. Legislação de Saúde), 2008.

BRASIL. Ministério da Saúde. Ministério da Educação. Portaria Interministerial n.421, de 3 de março de 2010a. Institui o Programa de Educação pelo Trabalho para a Saúde (PET-Saúde) e dá outras providências.

BRASIL. Ministério da Saúde. Portaria de Rede de Atenção à Saúde (RAS) nº4.279; de 30 de dezembro de 2010b. Disponível em: http://bvsms.saude.gov.br/bvs/saudelegis/gm/2010/prt4279_30_12_2010.html . Acesso em: 30 de maio de 2019.

BRASIL. Ministério da Saúde. Portaria de Rede da Rede de Cuidado à Pessoa com Deficiência, $\mathrm{n}^{\mathrm{0}} 793$; de 24 de abril de 2012a. Disponível em: http://bvsms.saude.gov.br/bvs/saudelegis/gm/2012/prt0793_24_04_2012.html. Acesso em: 30 de maio de 2019.

BRASIL. Secretaria dos Direitos Humanos e Secretaria Nacional de Promoção dos Direitos da Pessoa com Deficiência. Convenção sobre os Direitos das Pessoas com Deficiência. Ed.4, Brasília-DF, 2012b.

BRASIL. Secretaria dos Direitos Humanos e Secretaria Nacional de Promoção dos Direitos da Pessoa com Deficiência. Viver sem Limites: Plano Nacional dos Direitos da Pessoa com Deficiência. Brasília- DF, 2013. Disponível em: https://www.pessoacomdeficiencia.gov.br/app/sites/default/files/arquivos/\%5Bfield_generico _imagens-filefield-description\%5D_0.pdf. Acesso em: 20 de maio de 2019.

CARVALHO, S.A. VER-SUS: Relato de Experiência pelo Prisma da Comunicação Pública. Intercom - Sociedade Brasileira de Estudos Interdisciplinares da Comunicação 
XXXVIII Congresso Brasileiro de Ciências da Comunicação - Rio de Janeiro, RJ - 4 a 7/9/2015. Disponível em: http://portalintercom.org.br/anais/nacional2015/indiceautor.htm. Acesso em: um de dezembro de 2018.

CONASS. Número de Hospitais - SUS. Revista Online Consensus, Edição 11, matéria de capa, 2013. Disponível em: https://www.conass.org.br/consensus/numero-de-hospitais-brasilsus/. Acesso em: 16 de maio de 2019.

MS e OPAS. Contribuições Pragmáticas para a Organização dos Recursos Humanos em Saúde e para a História da Profissão Médica no Brasil - à Obra de Maria Cecília Donnangelo". Orgs.: André Mota, Joana Azevedo da Silva e Lilia Blima Schraiber; BrasíliaDF, 2004.

OMS. Relatório Mundial sobre a Deficiência/ World Report on desability. Tradução Lexicus Serviços Linguísticos. São Paulo, 2012. Disponível em: https://apps.who.int/iris/bitstream/handle/10665/44575/9788564047020 por.pdf;jsessionid $=\mathrm{C}$ FDDAAB8B88E3D9A4B579C024B6FD778? sequence=4 .Acesso em: um de junho de 2018

SÃO PAULO. SUBPREFEITURAS. Dados Demográficos dos Distritos Pertencentes às Sub-Prefeituras. Bairros da Freguesia do Ó e Brasilândia. Disponível em: https://www.prefeitura.sp.gov.br/cidade/secretarias/subprefeituras/subprefeituras/dados_demo graficos/index.php?p=12758. Acesso em: 18 de maio de 2019 .

FUNDAÇÃO SEAD. Secretaria de Planejamento e Gestão do Governo do Estado de São Paulo. PIB dos Municípios Paulistas 2002-2014. Disponível em: http://www.seade.gov.br/produtos/midia/2017/07/PIB_2002_2014_FINAL_reduzido.pdf. Acesso em: 24 de abril de 2019.

SMS. Prefeitura da Cidade de São Paulo. Estratégia Acompanhante de Saúde da Pessoa com Deficiência - Documento Norteador. Orgs. Área Técnica de Saúde da Pessoa com Deficiência; São Pulo, 2016. 


\section{8 - ANEXOS}

\section{1 - ANEXO 1: TERMO DE CONSENTIMENTO LIVRE E ESCLARECIDO}

Eu, Renata Pereira Sanches Guardia, convido os participantes do Fórum de Reabilitação, a participarem como voluntários do meu projeto de pesquisa do mestrado, intitulado: "O cuidado em rede para pessoas com deficiência e dor crônica", que tem como objetivo acompanhar o processo de produção de cuidado e de manejo das demandas de fisioterapia pela rede da pessoa com deficiência e dor crônica, no território da Freguesia do Ó / Brasilândia, a partir do Fórum de Reabilitação.

Para tanto, ser participante do Fórum de Reabilitação da Freguesia do Ó e Brasilândia se caracteriza como um critério de inclusão como voluntário do presente projeto de pesquisas, mesmo que seja uma única participação, sendo o critério de exclusão o não consentimento para a participação na pesquisa. A pesquisa tem a intenção de transformar em mapa os processos de produção de cuidado para as pessoas com deficiência e dor crônica, e se configura como uma intervenção à medida que dispara conversas, e pretende fazer pensar os diretamente envolvidos com o Fórum de Reabilitação da Freguesia do Ó/Brasilândia a respeito das demandas de fisioterapia. A participação como voluntário consiste em permitir que as falas feitas nas discussões dos encontros do Fórum, sejam utilizadas como material de pesquisa para a escrita de diários de campo pela pesquisadora. O objetivo é que esse material seja discutido e processado no Fórum, para que produza análise das práticas de cuidado que vem sendo operadas no território e, desse modo, a pesquisa feita em conjunto entre a pesquisadora e os voluntários da pesquisa, e essa produção conjunta faça parte dos resultados da pesquisa. Acredito que a pesquisa se justifica nesses moldes e nesse território, porque as questões que problematizo com o projeto são frequentemente pautadas no Fórum, e a pesquisa pode contribuir para fortalecer a rede de cuidados para pessoas com deficiência e dor crônica.

Durante a execução do projeto, há o risco de os participantes sentirem-se desconfortáveis diante de alguma questão relativa ao uso de suas falas, por exemplo (apesar de o indivíduo não ser identificado nelas). Mas o mesmo pode retirar o consentimento a qualquer momento e deixar de participar da pesquisa, sem que isso decorra em nenhum prejuízo para o indivíduo e nem interfira na sua participação no Fórum ou no seu trabalho. 
O voluntário tem o direito de: Receber resposta a qualquer pergunta e esclarecimento sobre os procedimentos, riscos, benefícios e outros relacionados à pesquisa; Se recusar a participar da pesquisa, assim como de retirar o consentimento a qualquer momento e deixar de participar do estudo, sem que isso acarrete em nenhum prejuízo para o mesmo; Ter a sua identidade mantida em sigilo, assim como mantidas em caráter confidencial as informações relacionadas à sua privacidade; Procurar esclarecimentos com o Comitê de Ética em Pesquisa da Faculdade de Saúde Pública da Universidade de São Paulo, no telefone (11) 3061-7779, email: coep@fsp.usp.br ou no endereço: Av. Dr. Arnaldo, 715 - Cerqueira César, São Paulo SP, assim como com o Comitê de Ética em Pesquisas da Secretaria Municipal de Saúde no email: smscep@gmail.com, no telefone: 11-33972464 ou no endereço: Rua General Jardim, n⿳36, $8^{\circ}$ andar - Vila Albuquerque, São Paulo-SP, em caso de dúvidas ou notificação de acontecimentos não previstos, ou para denúncias quanto a questões éticas.

Este Termo de Consentimento Livre e Esclarecido se apresenta em duas vias assinadas, uma ficará com o participante.

$\mathrm{Eu}$, _, após ter sido esclarecido sobre os termos de participação da pesquisa acima citada, declaro voluntariamente aceitar participar da mesma.

$$
\text { Assinatura do(a) voluntário(a):__ São Paulo, }
$$

de de 2018.

$\mathrm{Eu}$, Renata Pereira Sanches Guardia, declaro que forneci todas as informações referentes ao projeto de pesquisas ao participante, e disponibilizo meu contato pelo telefone: (11)95354-2114 e pelo e-mail: renataper@hotmail.com, para esclarecer qualquer dúvida referente à pesquisa.

Assinatura da pesquisadora: $\mathrm{Da}-$

ta: 


\title{
8.2 - ANEXO 2: AUTORIZAÇÃO DE PESQUISA STS FÓ/BRASILÂNDIA
}

\author{
PREFEITURA DO MUNICIPIO DE SÃO PAULO \\ COORDENADORIA REGIONAL DE SAÚDE NORTE \\ DISTRITO DE SAÚDE FREGUESIA DO Ó / BRASILÂNDIA
}

\section{AUTORIZAÇĀO}

Eu Jurema Westin Carvalho, RF: $314.290 .6 / 5$, abaixo assinado, Supervisora da Distrito de Saúde Freguesia do Ó/Brasilândia, autorizo a realização do projeto de pesquisa Cuidado em rede para pessoas com deficiência e dor crônica, cuja pesquisadora responsável é Renata Pereira Sanches Guardia, sendo a Instituiçăo Coordenadora USP. Fui informada pela responsável do estudo sobre justificativa, objetivos e procedimentos que serão realizados nos equipamentos deste Distrito de Saúde.

Esta instituição está ciente de suas co-responsabilidades como instituição coparticipante do presente projeto e o início da pesquisa está condicionado a apreciaçăo da CRSN e parecer de aprovaçăo de SMS.

Ao término da pesquisa os resultados deverão ser apresentados para os técnicos do Distrito de Saúde, bem como para os participantes da pesquisa.

Săo Paulo, 10 de outubro de 2017.

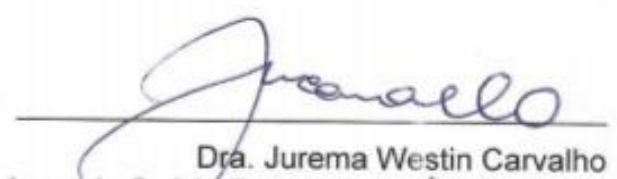

Supervisora de Saúdé Freguesia do Ó/Brasilândia 


\begin{tabular}{|l|l|l|}
\hline $\begin{array}{l}\text { REMETENTE: } \\
\text { Coordenadoria Regional de Saúde Norte }\end{array}$ & $\begin{array}{l}\text { MEMO N } \\
\text { 087/2017/ } \\
\text { DIRETORIA }\end{array}$ & $\begin{array}{l}\text { DATA: } \\
16 / 10 / 2017\end{array}$ \\
\hline $\begin{array}{l}\text { DESTINATARIO: SMS - Comitê de Ética em } \\
\text { Pesquisa - CEP }\end{array}$ & $\begin{array}{l}\text { ASSUNTO: Solicitaçăo de Pesquisa - } \\
\text { Renata Pereira Sanches Guardia }\end{array}$ \\
\hline
\end{tabular}

Sr. Coordenador :

Declaro conhecer o projeto de pesquisa intitulado, "Cuidado em rede para pessoas com deficiência e dor crônica", sob a responsabilidade da pesquisadora Renata Pereira Sanches Guardia, do Mestrado do Departamento de Praticas da Faculdade de Saúde Publica da - USP com orientaçâo da Profa. Dra. Yara Maria de Carvalho, a ser executado em Unidade dessa Coordenadoria Saúde do Municipio de Sâo Paulo.

Declaro ter ciência de que o presente projeto tem por objetivo, acompanhar o processo de produção e de manejo das demandas de fisioterapia pela rede da pessoa com deficiência e dor crônica, no território da Freguesia do O/Brasilândia, a partir do Fórum de Reabilitação. A metodologia de caráter qualitativo, envolvendo, entrevistas, observaçăo e construçấo conjunta do mapa dos processos de produçāo de cuidado para as pessoas alvo do
projeto.

Na CRS - Norte a pesquisa terá como base a o NIR Maria Cecilia Donnangelo, e campo os participantes do Fórum de Reabilitaçăo do território da Supervisão Técnica de Saúde da Freguesia do O/Brasilândia.

Contamos com a colaboração de todos para a realizaçăo da pesquisa e dos pesquisadores para a busca do agendamento dos procedimentos e com o retorno dos resultados aos interessados, enviamos a nossa anuência, para que se de prosseguimento na apreciação do projeto pelo Comitê de Ética em Pesquisa da SMS.

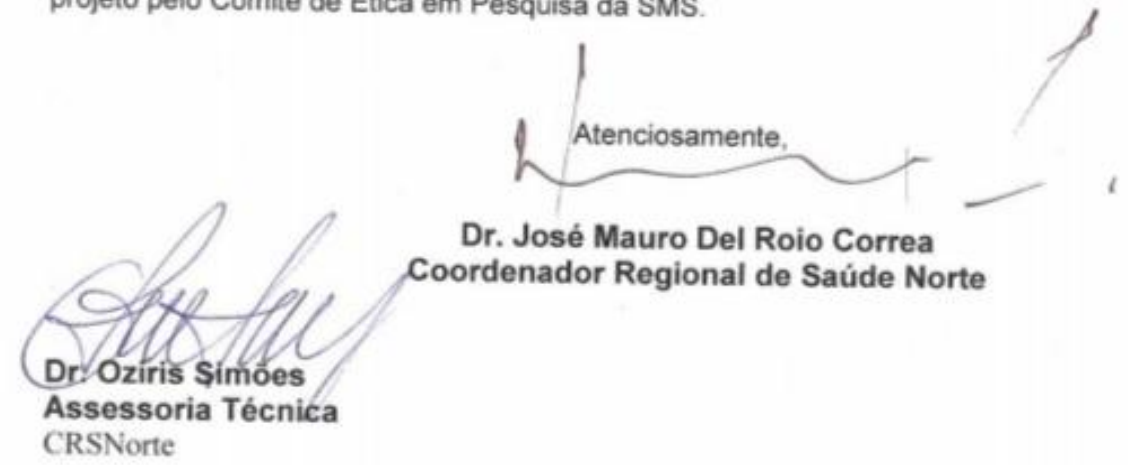

MORC/pst 


\section{USP - FACULDADE DE SAÚDE PÚBLICA DA UNIVERSIDADE DE SÄO PAULO - FSP/USP}

\section{PARECER CONSUBSTANCIADO DO CEP}

\section{DADOS DO PROJETO DE PESQUISA}

Titulo da Pesquisa: Cuidado em rede para pessoas com deficiência e dor crônica Pesquisador: RENATA PEREIRA SANCHES GUARDIA

Área Temática:

Versăo: 1

CAAE: 79458217.9 .0000 .5421

Instituição Proponente:Faculdade de Saúde Pública USP/SP

Patrocinador Principal: Financiamento Próprio

\section{DADOS DO PARECER}

\section{Número do Parecer: 2.563 .614}

\section{Apresentação do Projeto:}

Hipótese: a fila de espera por fisioterapia no municipio de São Paulo, no Sistema

Único de Saúde (SUS), tem se configurado como um problema, com uma demanda muito superior à capacidade de resposta dos serviços de reabilitação. $\mathrm{O}$ que leva à eleiçâo de prioridades e a uma longa espera de atendimento para certas condiçōes de saúde, além da desassistência. Pensar em rede e articular açōes para produzir cuidado junto com os usuários e familiares, pode significar uma mudança na qualidade do serviço, da prática e da saúde de todos, usuários e profissionais.

Método: A pesquisa será de natureza qualitativa e acontecerá no SUS, no municipio de São Paulo na Supervisão de Saúde da Freguesia do $O$ e Brasilândia. O campo de pesquisa proposto é o Fórum de Reabilitaçăo do território, visto que é um lugar privilegiado para articulação da rede, e para propor e pensar na produçâa de cuidado das pessoas com deficiência e dor crônica. Em relaçâo ao método de pesquisa, será utilizada a cartografia, que diferente de um mapa, não é estática, está sujeita aos movimentos de transformação da paisagem (Rolnik, 1989). O cartógrafo se utiliza das fontes mais variadas, mesmo das não escritas e não teóricas, e dá voz aos afetos. Nảo segue um protocolo normatizado, se utiliza dos olhos e do corpo vibrátil para fazer seu percurso de acordo com as afecçöes dos encontros (Rolnik, 1989). Os participantes do estudo entâo nâo sâo definidos a priori, vâo se delineando de acordo com a disponibilidade e interesse. Para registrar as

experiências vivenciadas no campo, serão utilizados um diário e um gravador, quando for

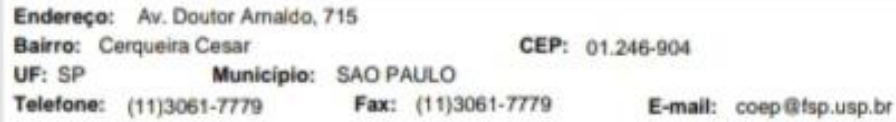




\section{USP - FACULDADE DE SAÚDE \\ PÚBLICA DA UNIVERSIDADE \\ DE SÃO PAULO - FSP/USP}

Continuaçằ đo Parecer: 2.563 .614

permitido e oportuno.

Objetivo da Pesquisa:

Acompanhar o processo de produção de cuidado e de manejo das demandas de fisioterapia pela rede da pessoa com deficiência e dor crônica, no território da Freguesia do $O$ / Brasilândia, a partir do Fórum de Reabilitação.

\section{Avaliação dos Riscos e Beneficios:}

Riscos:

Durante a execução do projeto há o risco de os participantes sentirem-se desconfortáveis diante de alguma questâo relativa ao serviço, ou ao cuidado, por exemplo. Mas os mesmos podem retirar o consentimento a qualquer momento e deixar de participar da pesquisa.

Beneficios:

Os individuos participantes poderão acompanhar e construir junto - usuários e profissionais - o processo de cuidado.

Comentários e Consideraçōes sobre a Pesquisa:

Pesquisa oportuna e relevante

Consideraçōes sobre os Termos de apresentação obrigatória:

Os termos estão todos adequados

Recomendaçöes:

Nenhuma recomendação

Conclusōes ou Pendências e Lista de Inadequações:

Pela aprovaçăo

Consideraçöes Finais a critério do CEP:

Este parecer foi elaborado baseado nos documentos abaixo relacionados:

\begin{tabular}{|c|c|c|c|c|}
\hline Tipo Documento & Arquivo & Postagem & Autor & Situaçâo \\
\hline $\begin{array}{l}\text { Informaçōes Básicas } \\
\text { do Projeto }\end{array}$ & $\begin{array}{l}\text { PB_INFORMAÇOES_BASICAS_DO_P } \\
\text { ROJETO 996822.pdf }\end{array}$ & $\begin{array}{c}23 / 10 / 2017 \\
20: 03: 04 \\
\end{array}$ & & Aceito \\
\hline Folha de Rosto & Renata_folha_de_rosto_pdf.pdf & $\begin{array}{c}23 / 10 / 2017 \\
19: 53: 10\end{array}$ & $\begin{array}{l}\text { RENATA PEREIRA } \\
\text { SANCHES GUARDIA }\end{array}$ & Aceito \\
\hline $\begin{array}{l}\text { TCLE / Termos de } \\
\text { Assentimento / }\end{array}$ & TCLE_PDF.pdf & $\begin{array}{c}18 / 10 / 2017 \\
17: 18: 25\end{array}$ & \begin{tabular}{|l|} 
RENATA PEREIRA \\
SANCHES GUARDIA
\end{tabular} & Aceito \\
\hline
\end{tabular}

Endereço: Av. Doutor Arnaldo, 715

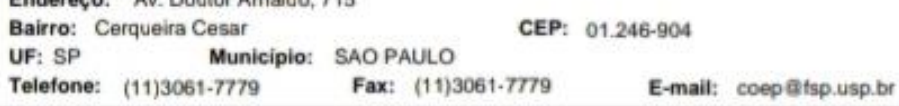




\section{USP - FACULDADE DE SAÚDE PÚBLICA DA UNIVERSIDADE DE SÄO PAULO - FSP/USP

Continuaça do Parecer: 2.563 .61

\begin{tabular}{|c|c|c|c|c|}
\hline $\begin{array}{l}\text { Justificativa de } \\
\text { Ausência }\end{array}$ & TCLE_PDF.pdf & $\begin{array}{c}18 / 10 / 2017 \\
17: 18: 25\end{array}$ & $\begin{array}{l}\text { RENATA PEREIRA } \\
\text { SANCHES GUARDIA } \\
\end{array}$ & Aceito \\
\hline $\begin{array}{l}\text { Projeto Detalhado / } \\
\text { Brochura } \\
\text { Investigador }\end{array}$ & $\begin{array}{l}\text { Projeto_Mestrado_Renata_PS_Guardia. } \\
\text { pdi }\end{array}$ & $\begin{array}{c}17 / 10 / 2017 \\
19: 27: 32\end{array}$ & $\begin{array}{l}\text { RENATA PEREIRA } \\
\text { SANCHES GUARDIA }\end{array}$ & Aceito \\
\hline $\begin{array}{l}\text { Declaraça de } \\
\text { Instituiçáo e } \\
\text { Infraestrutura }\end{array}$ & $\begin{array}{l}\text { Coordenadoria_Norte_memo_087_2017 } \\
\text { pdif }\end{array}$ & $\begin{array}{c}17 / 10 / 2017 \\
19: 21: 48\end{array}$ & $\begin{array}{l}\text { RENATA PEREIRA } \\
\text { SANCHES GUARDIA }\end{array}$ & Aceito \\
\hline $\begin{array}{l}\text { Declaraçáo de } \\
\text { Instituiçăo e } \\
\text { Infraestrutura }\end{array}$ & $\begin{array}{l}\text { Autorizacao_de_pesquisa_Supervisao.p } \\
\text { df }\end{array}$ & $\begin{array}{c}17 / 10 / 2017 \\
19: 21: 24\end{array}$ & $\begin{array}{l}\text { RENATA PEREIRA } \\
\text { SANCHES GUARDIA }\end{array}$ & Aceito \\
\hline
\end{tabular}

Situaçalo do Parecer:

Aprovado

Necessita Apreciaçăo da CONEP:

Nầo

SAO PAULO, 26 de Março de 2018

Assinado por:

Maria Regina Alves Cardoso

(Coordenador)

Endereço: Av. Doutor Amaldo, 715

Bairro: Cerqueira Cesas

CEP: $01.246-904$ 


\section{etica \\ EM PESQUISA - SMS \\ SECRETARIA MUNICIPAL DA \\ SAÚDE DE SĀO PAULO - SMS/SP}

\section{PARECER CONSUBSTANCIADO DO CEP}

\section{Elaborado pela Instituição Coparticipante}

\section{DADOS DO PROJETO DE PESQUISA}

Título da Pesquisa: Cuidado em rede para pessoas com deficiência e dor crônica

Pesquisador: RENATA PEREIRA SANCHES GUARDIA

Área Temática:

Versăo: 3

CAAE: 79458217.9 .3001 .0086

Instituiçăo Proponente: SECRETARIA MUNICIPAL DA SAUDE

Patrocinador Principal: Financiamento Próprio

\section{DADOS DO PARECER}

\section{Número do Parecer: 2.672 .880}

\section{Apresentaçăo do Projeto:}

Projeto de pesquisa para obtençấo do título de mestre pela Faculdade de Saúde Pública da USP.

Pesquisa de natureza qualitativa que ocorrerá na Supervisăo de Saúde da Freguesia do O - Brasilândia. 0 campo de estudo será o Fórum de Reabilitaçâo do território.

Serão 20 participantes.

A análise dos dados pressupōe a construçăo de um mapa mostrando as relaçōes e as conexōes de cuidado.

Para entender o mapa,o pesquisador trabalhará com observaçōes e narrativas a fim de encontrar os elementos que expliquem como se estabelecem as relaçōes e as conexóes.

\section{Objetivo da Pesquisa:}

Objetivo Primário:

Acompanhar o processo de produçăo de cuidado e de manejo das demandas de fisioterapia pela rede da pessoa com deficiência e dor crônica, no território da Freguesia do O/ Brasilândia, a partir do Fórum de Reabilitaçăo.

\section{Avaliaçăo dos Riscos e Beneficios:}

Durante a execuçăo do projeto, há o risco de os participantes sentirem-se desconfortáveis diante de alguma questão relativa ao serviço, ou ao cuidado, por exemplo. Mas os mesmos podem retirar o consentimento a qualquer momento e deixar de participar da pesquisa.

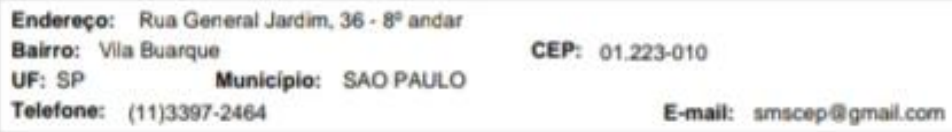




EM PESQUISA-SMS
SAÚDE DE SÄO PAULO -
SMS/SP

Continuaçào do Parecer: 2.672 .880

Beneficios:

Os individuos participantes do projeto poderão acompanhar e construir em rede a produção de cuidado, tendo a possibilidade de problematiza-lo em conjunto, e contribuir para a qualificação das práticas de cuidado.

Comentários e Consideraçōes sobre a Pesquisa:

Metodologia adequada ao objetivo de pesquisa.

Consideraçōes sobre os Termos de apresentação obrigatória:

A Folha de Rosto está corretamente preenchida, foram identificadas instituiçâo proponente e coparticipante, autorização para realização da pesquisa foi adequadamente apresentada.

TCLE, Cronograma, Orçamento detalhado e fonte financiadora estâo adequados.

\section{Recomendaçōes:}

Conclusões ou Pendências e Lista de Inadequaçōes:

Após análise das respostas, as pendências foram consideradas respondidas.

Consideraçōes Finais a critério do CEP:

Para inicio da coleta dos dados, o pesquisador deverá se apresentar na mesma instância que autorizou a realização do estudo (Coordenadoria, Supervisão, SMS/Gab, etc).

Salientamos que o pesquisador deve desenvolver a pesquisa conforme delineada no protocolo aprovado. Eventuais modificaçōes ou emendas ao protocolo devem ser apresentadas ao CEP de forma clara e sucinta, identificando a parte do protocolo a ser modificada e suas justificativas. Lembramos que esta modificaçâo necessitará de aprovação ética do CEP antes de ser implementada.

De acordo com a Res. CNS 466/12, o pesquisador deve apresentar os relatónios parciais e final atravès da Plataforma Brasil, icone Notificaçâo. Uma cópia digital (CD/DVD) do projeto finalizado deverá ser enviada à instância que autorizou a realizaçâo do estudo, via correio ou entregue pessoalmente, logo que o mesmo estiver concluido.

Este parecer foi elaborado baseado nos documentos abaixo relacionados:

Endereço: Rua General Jardim, $36-8^{\circ}$ andar
Bairro: Vila Buarque
$\begin{aligned} & \text { UF: SP } \\ & \text { Telefone: (11)3397-2464 }\end{aligned} \quad$ CEP: $01.223-010$




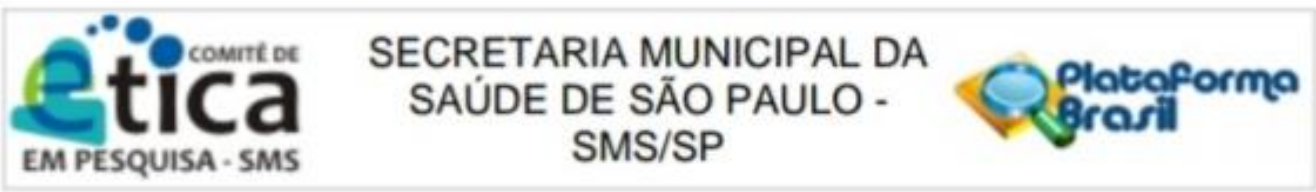

Continuacio on Partcer 2672 ase

\begin{tabular}{|c|c|c|c|c|}
\hline Tipo Documento & Arquivo & Postagem & Autor & Situação \\
\hline $\begin{array}{l}\text { Informaçōes Básicas } \\
\text { do Projeto }\end{array}$ & $\begin{array}{l}\text { PB_INFORMACCOES_BASICAS_DO_P } \\
\text { RO_JETO } 1101340 \text {.pdt }\end{array}$ & $\begin{array}{c}17 / 05 / 2018 \\
07: 12: 15\end{array}$ & & Aceito \\
\hline Outros & $\begin{array}{l}\text { Resposta_pendencias_apontadas_pared } \\
\text { er_CEP SMS versao2.docx }\end{array}$ & $\begin{array}{c}17 / 05 / 2018 \\
07: 11: 14\end{array}$ & $\begin{array}{l}\text { RENATA PEREIRA } \\
\text { SANCHES GUARDIA }\end{array}$ & Aceito \\
\hline $\begin{array}{l}\text { Projeto Detalhado / } \\
\text { Brochura } \\
\text { Investigador }\end{array}$ & $\begin{array}{l}\text { Projeto_Renata_PS_Guardia_Comite_S } \\
\text { MS_modificado_versao_2.pdi }\end{array}$ & $\begin{array}{c}17 / 05 / 2018 \\
07: 09-56\end{array}$ & $\begin{array}{l}\text { RENATA PEREIRA } \\
\text { SANCHES GUARDIA }\end{array}$ & Aceito \\
\hline Brochura Pesquisa & $\begin{array}{l}\text { Projeto_Renata_PSGuardia_Comite_ver } \\
\text { sao final_2.pdf }\end{array}$ & $\begin{array}{c}03 / 05 / 2018 \\
07: 10: 38\end{array}$ & $\begin{array}{l}\text { RENATA PEREIRA } \\
\text { SANCHES GUARDIA }\end{array}$ & Aceito \\
\hline Outros & $\begin{array}{l}\text { Resposta_pendencias_apontadas_pared } \\
\text { er CEP SMS_docx }\end{array}$ & $\begin{array}{c}03 / 05 / 2018 \\
07: 10: 13\end{array}$ & $\begin{array}{l}\text { RENATA PEREIRA } \\
\text { SANCHES GUARDIA }\end{array}$ & Aceito \\
\hline $\begin{array}{l}\text { TCLE/Termos de } \\
\text { Assentimento / } \\
\text { Justificativa de } \\
\text { Ausência }\end{array}$ & TCLE_nova_versao_word.docx & $\begin{array}{c}27 / 04 / 2018 \\
13: 33: 09\end{array}$ & $\begin{array}{l}\text { RENATA PEREIRA } \\
\text { SANCHES GUARDIA }\end{array}$ & Aceito \\
\hline $\begin{array}{l}\text { TCLE / Termos de } \\
\text { Assentimento / } \\
\text { Justificativa de } \\
\text { Ausência }\end{array}$ & TCLE_PDF.pdf & $\begin{array}{l}18 / 10 / 2017 \\
17: 18: 25\end{array}$ & $\begin{array}{l}\text { RENATA PEREIRA } \\
\text { SANCHES GUARDIA }\end{array}$ & Aceito \\
\hline $\begin{array}{l}\text { Projeto Detalhado / } \\
\text { Brochura } \\
\text { Investigador }\end{array}$ & $\begin{array}{l}\text { Projeto_Mestrado_Renata_PS_Guardia. } \\
\text { pdt }\end{array}$ & $\begin{array}{l}17 / 10 / 2017 \\
19: 27: 32\end{array}$ & $\begin{array}{l}\text { RENATA PEREIRA } \\
\text { SANCHES GUARDIA }\end{array}$ & Aceito \\
\hline
\end{tabular}

Situaçăo do Parecer:

Aprovado

Necessita Apreciaçăo da CONEP:

Năo

SAO PAULO, 24 de Maio de 2018

Assinado por:

SIMONE MONGELLI DE FANTINI

(Coordenador)

Enderece: Rua General Jandim, 36 - 8 andar

Bairre: Via Buarque

UF: SP Municipio: SAO PAULO

Telefone: (11)3097-2464

CEP: $01.223-010$

E-mail: smscepelgmail.com 


\section{6 - ANEXO 6: CURRÍCULO LATTES RENATA PEREIRA SANCHES GUARDIA}

Curriculo Lattes

\section{Renata Pereira Sanches Guardia}

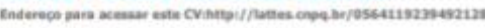

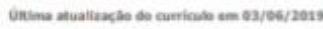

Resumo informado pelo autor

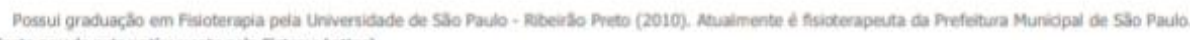
(Texto gerado automaticamente pelo Sistema Lattes)

Nome civil

Name Farata Mantia Sanches Giertis

Dados pessoais

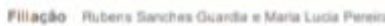

Nascimento sacarang - sae Paussp - Mnum

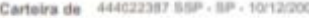

Identidade

cpr zas rasenea-ut

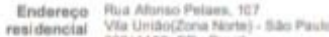

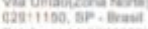

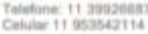

Enderese

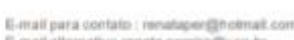

Formaçăo acadêmica/titulaçăo

2017 Mastado ant Mestad watdecion

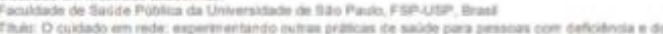

gíncia

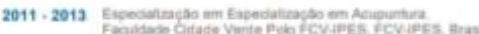

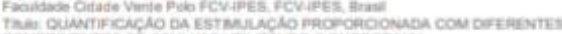

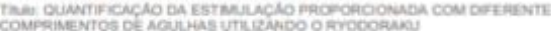

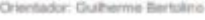

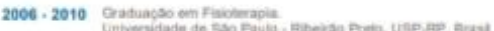

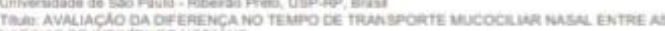

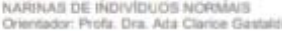

2011.2012

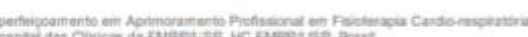

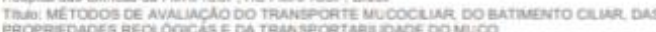

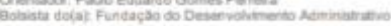

Formação complementar

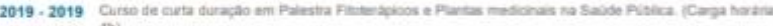

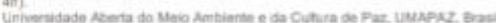

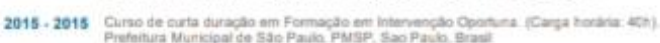

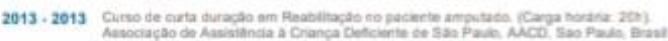

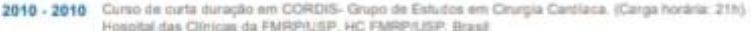

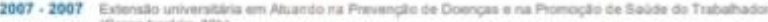

fCrya hadra Jem

Atuaçăo profissiona

LFaculdade de Medicina de AaC - Fuac

Vincuio
institucianal
2012

$2012 \cdot 2014$ 


\section{7 - ANEXO 7: CURRÍCULO LATTES YARA MARIA DE CARVALHO}

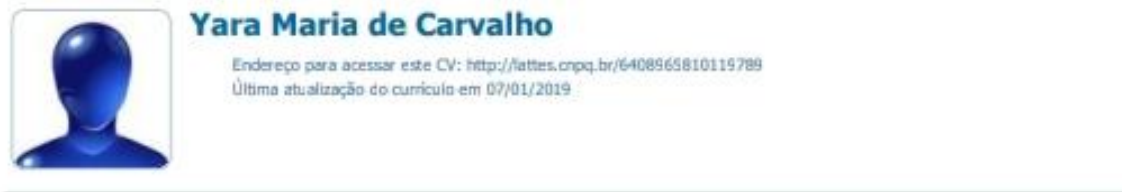

Possui licenciatura e bacharelado em Educação Fisica pela Universidade Estadual de Campinas (1989/1990), especialização em Saúde Pública pela Universidade Estadual de Campinas (1990), mestrado en Ciências do Esporte pela Universidade Estadual de Campinas (1993), doutorado em Saúde Coletiva na Faculdade de Ciências Médicas da Universidade Estadual de Campinas (1999) e livre-docência em Promoçào da Saúde pela Faculdade de Saúde Pública da Universidade de São Paulo; pós-doutorado em Ciências Humanas e Sav́de pela Universidade Estadual do Rio de Janeiro (2003), em Antropologia da Comunicação Visual pela Università La Sapienza di Roma, Itália (2004) e em Filosofia pela Universidad de Córdoba, Argentina (2010). Atualmente é Professora Associada da Universidade de São Paulo. Orienta mestrado e doutorado em Saúde Pública, na Faculdade de Saúde Pública/USP e em Ciências, na Escola de Educaçäo Fisica e Esporte/USP. Orienta mestrado profissional no Programa de Pós-Graduação Interunidades "Formação Interdisciplinar em Saúde"/FOUSP. Coordena o grupo de pesquisa CORPUS - Educação Física + Saúde Coletiva + Filosofia + Artes. Foi coordenadora adjunta do Pró-Ensino da Saúde e do Programa de Educação pelo Trabalho para a Saúde (Pró Ensino e PET -Saúde) - USP Capital (2012-2016) e boisista do Ministério da Saúde (2010-2012/2012-2014). Desenvolve projetos de pesquisa em Unidades Básicas de Saúde, Centros de Saúde Escola e Centro de Apoio Psicosocial. Trabalha com grupos de investigaçäo de outras unidades e departamentos da USP e com pesquisadores de outras universidades públicas brasileiras (UFRGS, Ufes, Unifesp, Unicamp). No exterior, foi Professora Visitante do Instituto Politécrico de Coimbra/Portugal; desenvolveu pesquisa com o Prof.Dr. Martin Bauer/London School of Economics/UK; e foi responsável pelo Convênio de Cooperação Internacional com a Universidad Nacional de Río Cuarto e La Plata/Argentina (2013-2015). O corpo na formaçẫo em saúde; a Educação Física no SUS; o corpo na contemporaneidade; corpo, arte e dínica; e as práticas corporais e o cuidado com o corpo na atenção básica/atenção primária em saúde são os temas de investigação que têm sido priorizados tendo como referência teórico-conceitual e metodológica a saúde coletiva, a filosofia e as artes. (Texto informado pelo autor)

Identificação

Yara Maria de Carvaliho

Nome em citaçōes bäbliogrăficas CARVALHO, Y. M.;CARVALHO, Yara Maria de

Endereço

Endereço Profissional Universidade de SB̈o Paulo, Escola de Educaço Física e Esporte da USP, Departamento de Pedagogia do Movimento do Compo Humano.

Rua Prolessar Melo Maraes 65

Codade Universitária

05508-900 - Sao Paulo, SP - Brasi

Teletone: (11) 30913135

Fax: (11) 38153342

URL da Hemepage: Http://www.corpus.efe.usp. br

Formação acadêmica/titulação

1994 - $19991 \quad \begin{aligned} & \text { Doutorado em Saúde Coletiva (Conceito CAPES 5). } \\ & \text { Universidade Estadual de Campinas, UNtCAMP, Brasi }\end{aligned}$

Titulo: A arte de farer a vida mehor; narrativas dos que fazem a festa de Achiropita, Ano de

obtençäo: 1999.

Bolsista do(a): Consehno Nacional de Deserwolvimento Centihico e Tecnoubgico, ONPq, Brasil. Palavras-chave: Lazer; Lidica; Citura; Cotidiano; Saúde coletiva

Grande área: Céncias da Saúde

Grande Area: Gểncias Humanas / Área: Socologia

Setores de atividade: Produtos e Servicos Recreativos, Calurais, Antisticos e Desportivos;

1991 - 1993 Cuicado A Saude das Perscas; Cuidado A Saude das Populaches Humanas.

Mestrado em Educaçäo Física (Concesto CNPEs 4).

Titulo: O mito atividade física/saúde, Ano de Obtençăo: 1993 .

Orientador: Gastäa Wagner de Sousa Campos

Bokista do(a): Conseho Nacional de Desermolvimento Cienthico e Tecnobibico, ONPq, Brasil. 


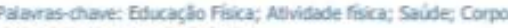

Grande breas Clences da sivise

Gande keas: Otndies da Saude / Area: Suide Coletiva

Grande Aver: Othois Humanas / Aver: Socoilogit

Setores de abividade: Edvcacilo; Salde Humana.

1991 - 1991

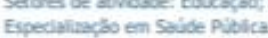

$1990-1990$

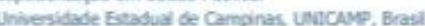

Eipedialisacis en Educacto Fisica no 30 Gras.

Univesidade Eradual de Campinas undawy, Brasi

Sobista do(a): Conseho Neoconal de Desenvolvimento Oentrico e Techolbgico, OVP4, Brasi.

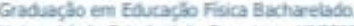

$1986-1990$

Unvesidade Esadua de Campinas, UndCave, Brasi

$1986-1969$

Graduaça em Fducacto Fisica Licendatura.

Univessidade Edastua de Campinar UNICAYs, Brest

$1970-1977$

Ensino Fundamertal (1" grat)

Coklojo Imperebtr Leogoidina, CLL Brasil.

Pós-doutorado e Livre-docência

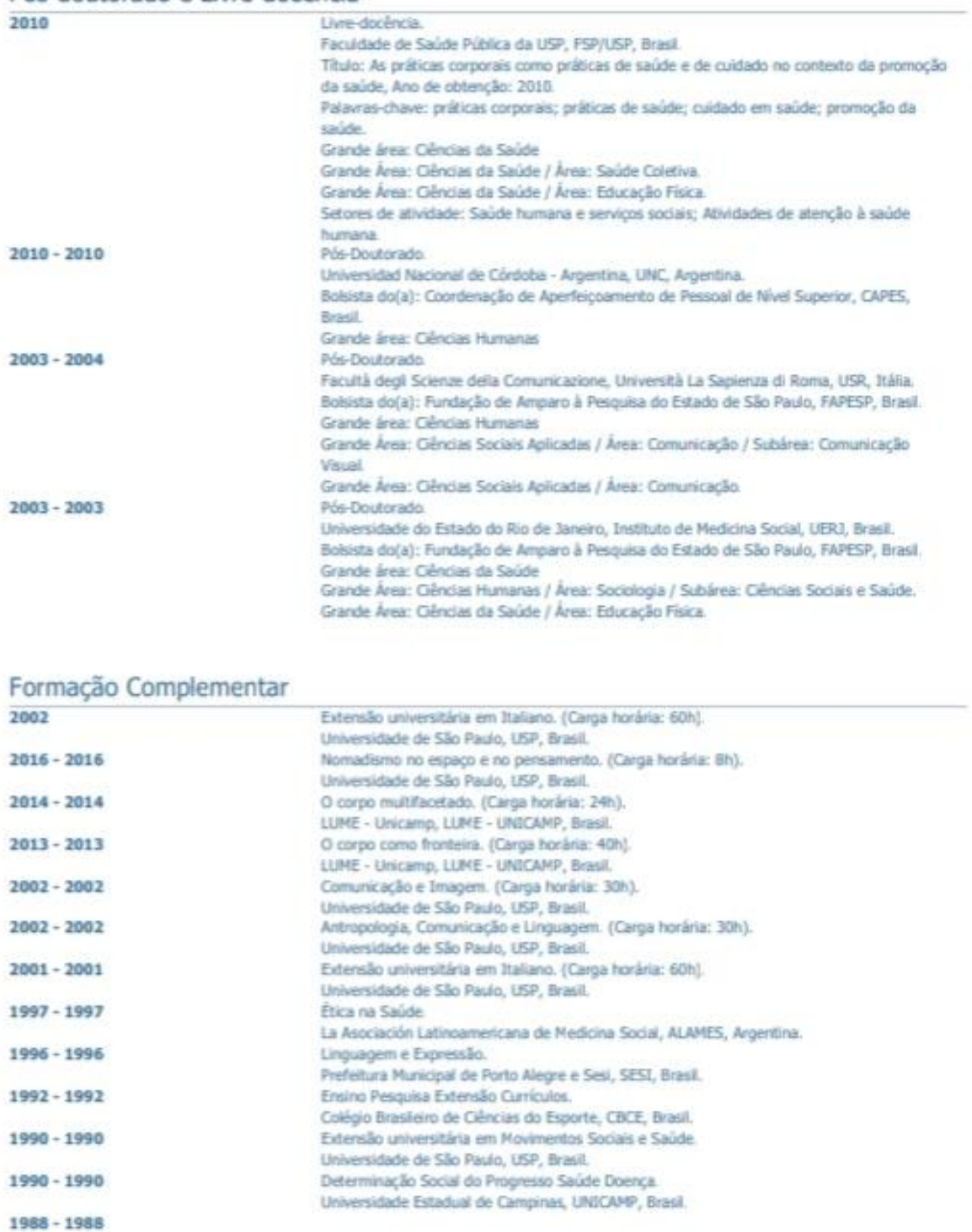

